\section{Pacific Northwest}

National Laboratory

Operated by Battelle for the

U.S. Department of Energy

\section{Geochemical Factors Affecting the Behavior of Antimony, Cobalt, Europium, Technetium, and Uranium in Vadose Sediments}

K. M. Krupka

R. J. Serne

December 2002

Prepared for CH2M HILL Hanford Group, Inc., and the U.S. Department of Energy under Contract DE-AC06-76RL01830 


\title{
Geochemical Factors Affecting the Behavior of Antimony, Cobalt, Europium, Technetium, and Uranium in Vadose Sediments
}

\author{
K. M. Krupka \\ R. J. Serne
}

December 2002

Prepared for CH2M HILL Hanford Group, Inc., and the U.S. Department of Energy under Contract DE-AC06-76RL01830

Pacific Northwest National Laboratory

Richland, Washington 99352 
PNNL-14126

\begin{abstract}
In developing the Field Investigation Report for the Waste Management Area S-SX at the Hanford Site, ${ }^{137}$ Cs was the only gamma emitting radionuclide of concern (Knepp 2002). ${ }^{a}$ However, in WMA $\mathrm{B}-\mathrm{BX}-\mathrm{BY}$, the spectral gamma logging data identify seven gamma emitting radionuclides, ${ }^{137} \mathrm{Cs},{ }^{125} \mathrm{Sb}$, ${ }^{152} \mathrm{Eu},{ }^{154} \mathrm{Eu},{ }^{60} \mathrm{Co},{ }^{235} \mathrm{U}$, and ${ }^{238} \mathrm{U}$ (DOE-GJPO 1998). ${ }^{\mathrm{b}}$ The geochemical behaviors of several of these radionuclides, ${ }^{125} \mathrm{Sb}$ and the two europium isotopes, have not been extensively investigated at the Hanford Site. This task was initiated to assure that our understanding of the geochemical properties affecting the environmental behavior of these radionuclides reflects the current state of knowledge. A literature review was conducted to assess the important oxidation/reduction, aqueous speciation, solubility, and adsorption processes affecting the environmental behavior of antimony, cobalt, europium, technetium, and uranium in vadose zone sediments with low-organic matter content in semi-arid environments such as those at the Hanford Site. Technetium-99 was included in this task because of its importance in the long-term risk calculations. This report presents the results of this literature review.
\end{abstract}

${ }^{a}$ Knepp AJ. 2002. Field Investigation Report for Waste Management Area S-SX. RPP-7884, Rev. 0, CH2M HILL Hanford Group, Inc., Richland, Washington.

${ }^{b}$ DOE-GJPO (U.S. Department of Energy, Grand Junction Project Office). 1998. Vadose Zone Characterization Project at the Hanford Tank Farms: BX Tank Farm Report. GJO-HAN-19, U.S. Department of Energy, Grand Junction Project Office, Grand Junction, Colorado. 
PNNL-14126

\section{Executive Summary}

Our knowledge of the environmental behavior of antimony is limited compared to other metals. Under natural environmental conditions, $\mathrm{Sb}(\mathrm{V})$ and $\mathrm{Sb}(\mathrm{III})$ are the stable oxidation states under oxidizing and reducing conditions, respectively, based on equilibrium thermodynamic considerations. However, $\mathrm{Sb}(\mathrm{V})$ and $\mathrm{Sb}(\mathrm{III})$ have been found coexisting in a wide range of natural aqueous systems contrary to thermodynamic predictions. Proposed explanations for the observed metastability of $\mathrm{Sb}(\mathrm{V})$ and $\mathrm{Sb}(\mathrm{III})$ include biotic processes and slow rates of redox reactions. Limited thermodynamic data for antimony aqueous species and solids preclude quantitative aqueous speciation and solubility calculations for $\mathrm{Sb}(\mathrm{V})$ and $\mathrm{Sb}$ (III) over the entire Eh-pH range of conditions. Under oxic conditions to slightly reducing conditions, the hydrolytic species $\mathrm{Sb}(\mathrm{OH})_{6}{ }^{-}$is calculated to be the dominant antimony aqueous species at $\mathrm{pH}$ values greater than approximately 2.5 . At moderately reducing conditions, antimony speciation is dominated by the hydrolytic species $\mathrm{Sb}(\mathrm{OH})_{3}{ }^{\mathrm{o}}$ (aq) at $\mathrm{pH}$ values from 2 to 12 .

The concentrations of antimony in soils and sediments are likely controlled by adsorption reactions, but very little is known about the adsorption/desorption behavior of $\mathrm{Sb}(\mathrm{V})$ or $\mathrm{Sb}(\mathrm{III})$. Antimony concentrations in soils under oxidizing conditions are not limited by solubility reactions. Because dissolved $\mathrm{Sb}(\mathrm{V})$ is present primarily as the anion $\mathrm{Sb}(\mathrm{OH})_{6}{ }^{-}$over almost the entire $\mathrm{pH}$ range, the adsorption of $\mathrm{Sb}(\mathrm{V})$ to mineral surfaces is likely significant at acidic $\mathrm{pH}$ conditions, but limited to negligible as $\mathrm{pH}$ increases from circumneutral to highly basic $\mathrm{pH}$ values. Anionic aqueous complexes are electrostatically repelled by most soil surfaces, which have an inherent negative charge at high $\mathrm{pH}$ conditions. Therefore, under basic $\mathrm{pH}$ and oxidizing conditions, antimony should be highly mobile in the geochemical environment. An adsorption study of antimony onto sediment from the Hanford Site indicated that the adsorption of antimony is very low in Hanford soils contacting high-salt, high $\mathrm{pH}$ solutions (i.e., simulated single-shell tank liquors). Under reducing conditions, antimony concentrations may be limited by the solubility of $\mathrm{Sb}$ (III) sulfides, such as stibnite $\left(\mathrm{Sb}_{2} \mathrm{~S}_{3}\right)$.

Although cobalt can exist in the +2 and +3 oxidation states, $\mathrm{Co}(\mathrm{II})$ is the stable valence state in water under most geochemical conditions. Cobalt(III) decomposes under Eh-pH conditions common for most natural waters, but complexation by ligands, such as EDTA and $\mathrm{NH}_{3}$, can stabilize the $\mathrm{Co}(\mathrm{III})$ valence state and allow it to persist in solution. Under oxidizing and moderately reducing conditions, the uncomplexed ion $\mathrm{Co}^{2+}$ is the dominant cobalt aqueous species at $\mathrm{pH}$ values less than 9.5. At $\mathrm{pH}$ values from 9.5 to 13.5 , the hydrolytic species $\mathrm{Co}(\mathrm{OH})_{2}{ }^{\circ}$ (aq) becomes dominant. Under very reducing conditions in the presence of dissolved sulfide, $\mathrm{Co}(\mathrm{II})$ bisulfide species, such as $\mathrm{Co}(\mathrm{HS})_{2}{ }^{\circ}$ (aq), likely dominate the aqueous speciation. For most environmental conditions relevant to the Hanford vadose zone, pure cobalt-bearing minerals are not expected to act as solubility controls. No discrete cobalt minerals have been identified in surface sediment and soil systems. Cobalt is often found in solid solution with other elements, such as $\mathrm{Fe}(\mathrm{II}), \mathrm{Fe}(\mathrm{III}), \mathrm{Mn}(\mathrm{III}), \mathrm{Cu}(\mathrm{II}), \mathrm{Mg}(\mathrm{II}), \mathrm{Cr}(\mathrm{III})$, and $\mathrm{Sn}(\mathrm{IV})$, in minerals rich with such elements.

The adsorption of cobalt has been studied on a variety of minerals, sediments, soils, and crushed rock materials. The adsorption of cobalt in sediments and soils is closely linked to its oxidation state, and is largely controlled by the presence of iron and manganese oxides and clay minerals. In the absence of organic complexants, cobalt is moderately-to-highly adsorbed on minerals, and cobalt $\mathrm{K}_{\mathrm{d}}$ values 
commonly reported in the literature range from $10^{3}$ to $10^{5} \mathrm{~mL} / \mathrm{g}$. Recent studies indicate that at high surface loadings, surface-mediated precipitation processes may be responsible for the high adsorption (i.e., large $K_{d}$ values) observed for cobalt. The presence of some inorganic ligands, such as cyanide and possibly nitrite, and other dissolved cations, such as the alkali and alkaline earth ions, can decrease cobalt adsorption.

Complexation of cobalt by organic ligands, such as EDTA, also significantly reduces cobalt adsorption at near neutral and basic $\mathrm{pH}$ values, and has been identified as the cause for the enhanced ${ }^{60} \mathrm{Co}$ mobility observed at several nuclear waste disposal sites. This decrease in cobalt adsorption is typically caused by the formation of anionic cobalt complexes, which do not readily adsorb on mineral surfaces at basic $\mathrm{pH}$ values. Cobalt(II) is initially complexed to form the anionic complex $\mathrm{Co}^{\mathrm{II}} \mathrm{EDTA}^{2-}$. This complex however then dissociates via a complex series of reactions that result in the oxidation of Co(II) to $\mathrm{Co}(\mathrm{III})$, formation of $\mathrm{Co}^{\mathrm{III}} \mathrm{EDTA}$, and suite of resulting adsorbates $\mathrm{Co}^{2+}, \mathrm{Co}^{\mathrm{II}} \mathrm{EDTA}^{2-}, \mathrm{FeEDTA}$, and AlEDTA $^{-}$that compete for the EDTA and surface adsorption sites.

The results of several Co(II) adsorption studies using Hanford Site sediments suggest that cobalt is highly immobile (i.e., $\mathrm{K}_{\mathrm{d}}>10^{3} \mathrm{~mL} / \mathrm{g}$ ) for natural groundwater conditions at the Hanford Site in the absence of organic chelating agents, such as EDTA. However, ${ }^{60} \mathrm{Co}$ is known to be mobile in both the vadose zone and groundwater in some waste types leaked from tanks or intentionally discharged to cribs and specific retention trenches at the Hanford Site, such as some waste streams coming from the uranium recovery process or from the $\mathrm{B}$ Plant isotope recovery processes. In the case of the B Plant waste streams, the ${ }^{60} \mathrm{Co}$ species is likely to involve organic chelating agents used in the isotope recovery processes. Little is known however, about the speciation of the mobile ${ }^{60} \mathrm{Co}$ species associated with the uranium recovery waste streams.

The most stable oxidation state for europium is +3 . Europium is the only lanthanide however, for which the +2 oxidation state is sufficiently stable under natural conditions to affect its mineralogy and aqueous chemistry. Thermodynamic calculations indicate that the stability of $\mathrm{Eu}(\mathrm{II})$ is restricted to circumneutral $\mathrm{pH}$ values at extremely reducing conditions. Europium(III) readily forms complexes with dissolved ligands present in natural waters. In the absence of dissolved sulfate, the uncomplexed ion $\mathrm{Eu}^{+3}$ is the dominant $\mathrm{Eu}(\mathrm{III})$ aqueous species predicted at acidic $\mathrm{pH}$ conditions from thermodynamic data. With the addition of dissolved sulfate, the $\mathrm{Eu}(\mathrm{III})$ sulfate complex $\mathrm{EuSO}_{4}{ }^{+}$will replace $\mathrm{Eu}^{+3}$ as the dominant $\mathrm{Eu}(\mathrm{III})$ aqueous species at acidic $\mathrm{pH}$ conditions. However, at $\mathrm{pH}$ values from 6 to greater than 13 , thermodynamic calculations indicate that the aqueous speciation of $\mathrm{Eu}(\mathrm{III})$ will be dominated by the formation of carbonate complexes, such as $\mathrm{Eu}(\mathrm{OH})_{2} \mathrm{CO}_{3}{ }^{\circ}$ (aq) and $\mathrm{Eu}(\mathrm{OH})_{2} \mathrm{CO}_{3}{ }^{-}$. The formation of strong carbonate-complexes, especially $\mathrm{Eu}(\mathrm{OH})_{2} \mathrm{CO}_{3}{ }^{-}$, is inconsistent with the low solubility and high adsorption properties observed in geochemical studies of Eu(III) at basic $\mathrm{pH}$ conditions. Essentially no information is available for the aqueous geochemistry and environmental behavior of $\mathrm{Eu}(\mathrm{II})$. Given the similarities in their ionic radii, the $\mathrm{Eu}^{+2}$ ion will likely have a geochemical behavior similar to $\mathrm{Sr}^{+2}$, and substitute for $\mathrm{Ca}^{+2}$ in minerals.

Europium(III) is considered sparingly soluble in environmental systems. Its low solubility may be a contributing factor to the large partition (distribution) coefficient, $\mathrm{K}_{\mathrm{d}}$, values that have been experimentally determined for europium. Europium(III) may exist as a primary component in several solid oxides, hydroxides, halides, hydroxyhalides, oxyhalides, sulfides, phosphates, carbonates, sulfates, 
and nitrates present in tank sludges and contaminated vadose zone sediments, but thermodynamic constants for such solids are limited.

Europium(III), like other trivalent elements, is highly sorbed in sediments (i.e., exhibits high $\mathrm{K}_{\mathrm{d}}$ values) and thus immobile in most environments. The mobility of trivalent elements in the environment however increases at acidic $\mathrm{pH}$ values and in high ionic strength solutions. Few studies were identified for europium adsorption on sediment samples from the Hanford Site. Based on a published geochemical data package compiled to support the performance assessment studies of immobilized low-activity tank wastes at the Hanford Site, a range of $\mathrm{K}_{\mathrm{d}}$ values from 100 to $1,500 \mathrm{ml} / \mathrm{g}$ was recommended for the radionuclide group "Ac, $\mathrm{Am}, \mathrm{Ce}, \mathrm{Cm}, \mathrm{Eu}$ " for the "chemically impacted far field in sand sequence" environment where the $\mathrm{pH}$ is in the range from 8 to 11 . Because trivalent elements strongly adsorb to sediment particles, there is potential for colloid-facilitated transport of europium and other trivalent elements in vadose zone and groundwater systems. The reader is cautioned however, that the importance of colloid-facilitated migration, especially in environmental systems that do not involve fracture flow of pore water or groundwater, is still the subject of debate.

Technetium exists in valence states from +7 to -1 . In natural environments, the most stable valence states of technetium are +7 and +4 under oxidizing and reducing conditions, respectively. The environmental behavior of technetium under oxidizing conditions has been studied extensively. Dissolved technetium is present in oxic systems as the aqueous $\mathrm{Tc}(\mathrm{VII})$ oxyanion species $\mathrm{TcO}_{4}{ }^{-}$, which is essentially nonadsorptive (i.e., $\mathrm{K}_{\mathrm{d}}$ values are $\approx 0 \mathrm{ml} / \mathrm{g}$ ) at circumneutral and basic $\mathrm{pH}$ values and also highly soluble. The concentration of Tc(VII) in the vadose zone and groundwater will therefore not be limited by adsorption or solubility processes, and thus will be highly mobile in oxic environments.

Under reducing conditions, technetium is present in the +4 oxidation state, which is sparingly soluble and highly sorbed. Technetium(IV) is therefore considered to be essentially immobile in reducing subsurface environments. However, additional studies are needed to determine the stability constants and potential roles of important complexing ligands, such as carbonate, phosphate, sulfide, and others, on the adsorption and solubility of Tc(IV). It is generally assumed that technetium is released to and present in the vadose zone and groundwater at the Hanford Site as oxidized Tc(VII). The results of recent studies of waste samples from certain underground storage tanks at the Hanford Site indicate that a significant fraction of the technetium in the waste is present in the +4 oxidation state. Future conceptual models for the release of technetium from the Hanford underground storage tanks will need to consider the potential mobility of Tc(IV) in the near-field, vadose sediments and potential interactions of organics present in the tanks with respect to complexing and stabilizing Tc(IV) and possibly other intermediate valance states of dissolved technetium.

Uranium can exist in the $+3,+4,+5$, and +6 valence states in aqueous environments. Uranium(VI) (i.e., uranyl) and $\mathrm{U}(\mathrm{IV})$ are the most common oxidation states of uranium in natural environments, and are stable, respectively, under oxidizing and reducing conditions. Dissolved U(III) easily oxidizes to U(IV) under most reducing conditions found in nature, and $U(V)$ readily disproportionates to $U(I V)$ and $U(V I)$. Under reducing conditions, the speciation of $\mathrm{U}(\mathrm{IV})$ is dominated by the neutral aqueous species $\mathrm{U}(\mathrm{OH})_{4}{ }^{\circ}(\mathrm{aq})$ at $\mathrm{pH}$ values greater than 2 . The aqueous speciation of $\mathrm{U}(\mathrm{VI})$ in carbonate-containing waters at near neutral and basic higher $\mathrm{pH}$ values is dominated by a series of strong anionic carbonate complexes, such as $\mathrm{UO}_{2}\left(\mathrm{CO}_{3}\right)_{2}{ }^{2-}$ and $\mathrm{UO}_{2}\left(\mathrm{CO}_{3}\right)_{3}{ }^{4-}$, which considerably enhance the mobility of uranium 
under oxidizing conditions. Formation of these U(VI) carbonate complexes at $\mathrm{pH}$ values greater than 6 significantly increases the solubility of dissolved uranium, and decreases uranium adsorption on mineral surfaces due to the anionic nature of these complexes. The Hanford vadose zone and upper unconfined aquifer environments contain adequate concentrations of dissolved carbonate to have these uranyl carbonate complexes dominate the aqueous speciation of uranium. There has been direct verification the dominance of the aqueous uranyl carbonate species in vadose zone pore waters from Hanford borehole 299-E33-45.

Under reducing conditions or near a uranium source where elevated concentrations of uranium may exist, uranium mineral dissolution, precipitation, and coprecipitation processes become increasingly important and several uranium (co)precipitates may form depending on the environmental conditions. Uranium(IV) is considered relatively immobile under reducing conditions, because U(IV) readily precipitates as sparingly soluble minerals, such as uraninite $\left(\mathrm{UO}_{2}\right)$. Near sources of uranium release, solubility processes are particularly important for U(VI) in those sediments that become partially saturated with water or completely dry between periods of recharge, such as vadose zone sediments. Under these conditions, the concentration of uranium in the residue pore fluids may exceed the solubility limits for U(VI)-containing minerals and/or coprecipitates with other minerals, such as iron oxides. Characterization studies at several DOE sites, including two recent studies of uranium-contaminated sediments from the Hanford Site, indicate that sediments and soils contaminated from disposal or spills of uranium-containing liquid wastes at these sites can contain uranium minerals or coprecipitates. Detailed sediment characterization studies of contaminated sediments from borehole 299-E33-45 near tank 241-BX-102 and the near surface sediments from the Hanford 300 Area (Serne et al. 2002) ${ }^{\mathrm{a}}$ suggest the possible presence of U(VI) minerals such as clarkeite, uranophane, soddyite, boltwoodite, weeksite, uranyl phosphate, and meta-autunite.

Under oxidizing conditions in the far field away from input sources of uranium contamination, U(VI) concentrations in sediments and soils will be controlled by surface adsorption processes. Uranium(VI) adsorbs onto a variety of minerals and related phases, including clays, oxides, silicates, and natural organic material. Aqueous $\mathrm{pH}$ has a significant effect on $\mathrm{U}(\mathrm{VI})$ adsorption due to the consequence of $\mathrm{pH}$ on $\mathrm{U}(\mathrm{VI})$ aqueous speciation and the number of exchange sites on variable charged surfaces of minerals. Depending on the adsorbent, $\mathrm{U}(\mathrm{VI})$ adsorption in carbonate-containing aqueous solutions is low at $\mathrm{pH}$ values less than 3 , increases rapidly with increasing $\mathrm{pH}$ from $\mathrm{pH} 3$ to 5 , reaches a maximum in adsorption in the $\mathrm{pH}$ range from $\mathrm{pH} 5$ to $7-8$, and then decreases with increasing $\mathrm{pH}$ at $\mathrm{pH}$ values greater than 7 . The increase in $\mathrm{U}(\mathrm{VI})$ adsorption onto sediments from acidic to near neutral $\mathrm{pH}$ values is a consequence of the dominant $\mathrm{U}(\mathrm{VI})$ aqueous species being cationic and neutral over this $\mathrm{pH}$ range. However, the subsequent decrease in $\mathrm{U}(\mathrm{VI})$ adsorption with increasing basic $\mathrm{pH}$ values results from $\mathrm{U}(\mathrm{VI})$ aqueous speciation

a Serne RJ, CF Brown, HT Schaef, EM Pierce, MJ Lindberg, Z Wang, PL Gassman, and JG Catalano. 2002. 300 Area Uranium Leach and Adsorption Project, PNNL-14022, Pacific Northwest National Laboratory, Richland, Washington. 
being dominated by anionic carbonate complexes. Several studies of the adsorption of U(VI) on sediments from the Hanford Site have been completed. A recent published review of the results from these studies indicated that uranium adsorption is relatively low (e.g., $\mathrm{K}_{\mathrm{d}}$ values typically from 0.2 to $4 \mathrm{~mL} / \mathrm{g}$ ) for natural groundwater conditions at the Hanford Site. 
PNNL-14126

\section{Acronyms and Abbreviations}

\begin{tabular}{|c|c|}
\hline AEM & analytical electron microscopy \\
\hline am & amorphous \\
\hline CCM & constant capacitance model \\
\hline cr & crystalline \\
\hline DDLM & diffuse double layer model \\
\hline DIRB & dissimilatory iron reducing bacteria \\
\hline DLM & diffuse layer model \\
\hline DOE & U.S. Department of Energy \\
\hline DPACSV & differential pulse adsorptive stripping voltametry \\
\hline DTPA & diethylenetriaminepentaacetate \\
\hline DWS & drinking water standard \\
\hline EDS & energy-dispersive X-ray spectroscopy \\
\hline EDTA & ethylenediaminetetraacetate acid \\
\hline $\mathrm{Eh}$ & $\begin{array}{l}\text { electrical potential, a measure of redox state; relative to the standard hydrogen electrode } \\
\text { in volts or millivolts }\end{array}$ \\
\hline EMP & electron microprobe \\
\hline EXAFS & extended X-ray absorption fine structure spectroscopy \\
\hline FIR & field investigation report \\
\hline HEDTA & hydroxyethylethylenediaminetriacetate acid \\
\hline $\mathrm{K}_{\mathrm{d}}$ & partition coefficient or distribution coefficient; terms commonly used interchangeably \\
\hline LIFS & laser-induced fluorescence spectroscopy \\
\hline M & molarity, moles of solute per liter solvent \\
\hline $\mathrm{m}$ & molality, moles of solute per $1000 \mathrm{~g}$ solvent) \\
\hline MCL & maximum contaminant level \\
\hline NIST & U.S. National Institute of Standards and Technology \\
\hline NTA & nitrilotriacetic acid \\
\hline $\mathrm{pH}$ & negative logarithm of the hydrogen ion activity \\
\hline pHzpc & $\mathrm{pH}$ for zero point of charge \\
\hline ppb & parts per billion (equivalent to $\mu \mathrm{g} / \mathrm{L}$ ) \\
\hline ppm & parts per million (equivalent to $\mathrm{mg} / \mathrm{L}$ ) \\
\hline PNL & $\begin{array}{l}\text { Pacific Northwest Laboratory. In 1995, DOE formally changed the name of the Pacific } \\
\text { Northwest Laboratory to the Pacific Northwest National Laboratory. }\end{array}$ \\
\hline PNNL & Pacific Northwest National Laboratory \\
\hline REE & rare-earth element \\
\hline $\mathrm{SCM}$ & electrostatic surface complexation model \\
\hline SEM & scanning electron microscopy \\
\hline$t^{1 / 2}$ & half life \\
\hline TBP & tributyl phosphate \\
\hline TLM & triple layer model \\
\hline $\mathrm{UFA}^{\mathrm{TM}}$ & unsaturated flow apparatus \\
\hline WMA & waste management area \\
\hline
\end{tabular}


PNNL-14126

XAFS X-ray absorption fine structure

XANES X-ray absorption near-edge structure

XMP X-ray microprobe

XPS X-ray photoelectron spectroscopy

XRD X-ray diffraction 
PNNL-14126

\section{Acknowledgments}

This work was conducted as part of the Tank Farm Vadose Zone Project led by CH2M HILL Hanford Group, Inc., in support of the U.S. Department of Energy's Office of River Protection. The authors wish to acknowledge Anthony J. Knepp with CH2M HILL Hanford Group, Inc. (CH2M HILL) for his funding of this work, and Thomas E. Jones with CH2M HILL and Marc I. Wood with Fluor Hanford, Inc. for their technical input during the completion of this effort.

We would also like to thank Clark W. Lindenmeier with Pacific Northwest National Laboratory (PNNL) for his technical review of this report. The authors also acknowledge the editorial review by Karrol D. Lehman with Mid-Columbia Engineering, and word processing support by Ginger Benecke with Jacobs Engineering. 
PNNL-14126

\section{Contents}

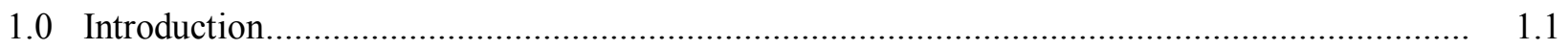

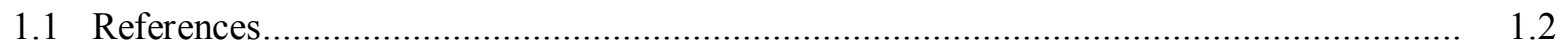

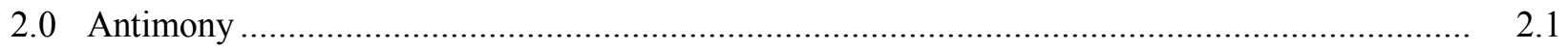

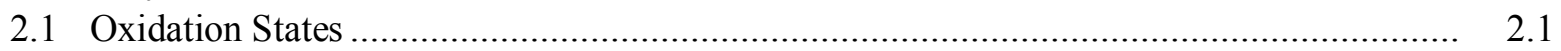

2.2 Aqueous Speciation ................................................................................................. 2.1

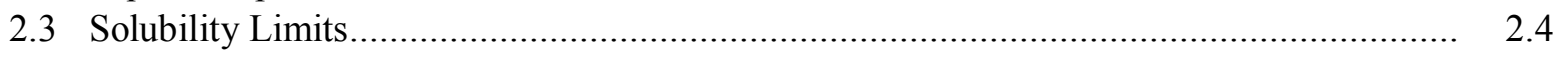

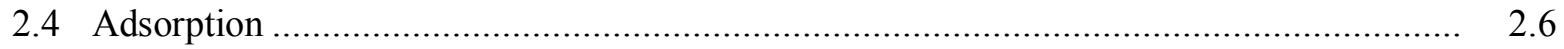

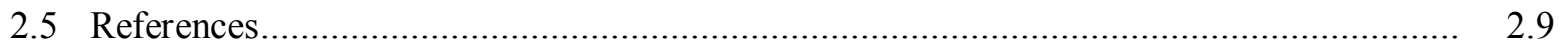

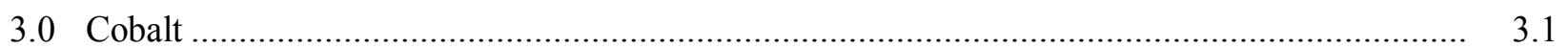

3.1 Oxidation States ........................................................................................ 3.1

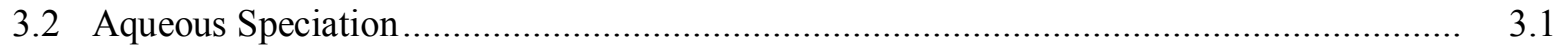

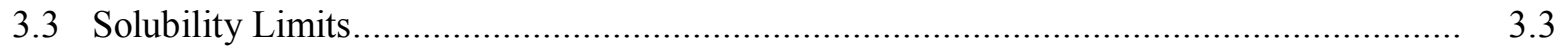

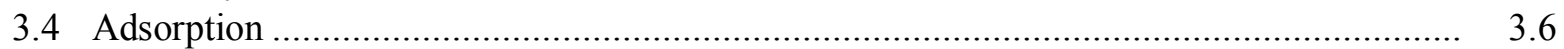

3.4.1 Adsorption in the Absence of Organic Ligands............................................... 3.6

3.4.2 Adsorption in the Presence of Organic Ligands ................................................ 3.8

3.4.3 Hanford Sediment Cobalt Adsorption Studies ................................................ 3.10

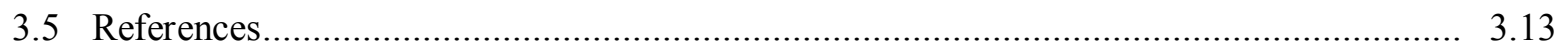

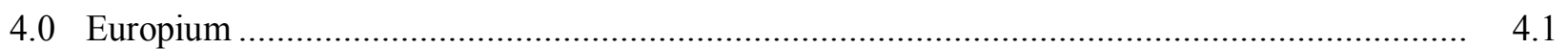

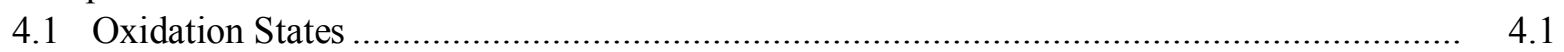

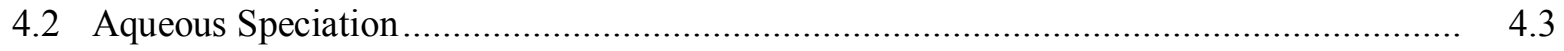

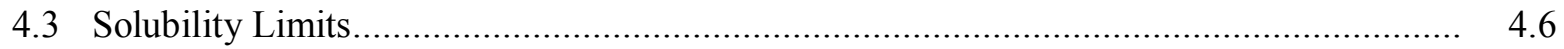

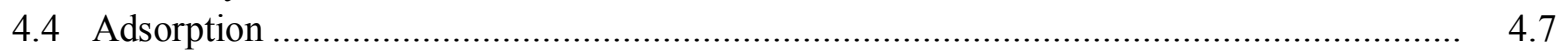

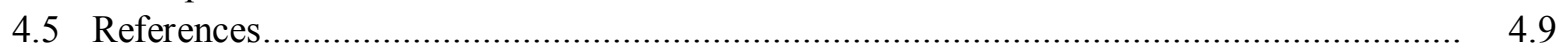

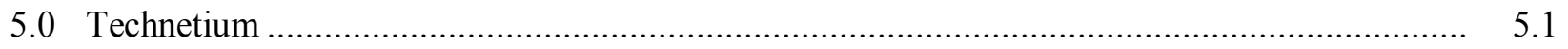

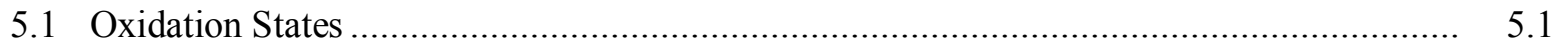

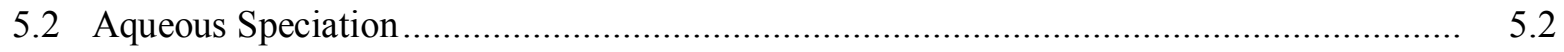

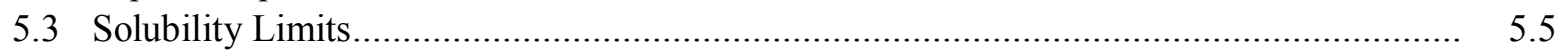

5.4 Adsorption ...................................................................................................... 5.6

5.4.1 $\mathrm{K}_{\mathrm{d}}$ Studies for Technetium on Sediment Materials....................................... 5.7

5.4.2 $\mathrm{K}_{\mathrm{d}}$ Studies for Technetium on Other Geologic Sediment Materials ...................... 5.9

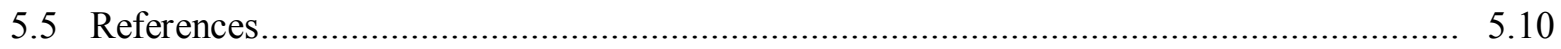

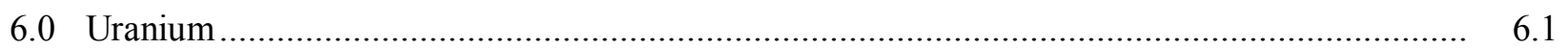

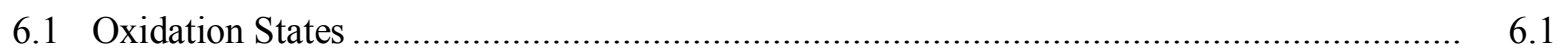

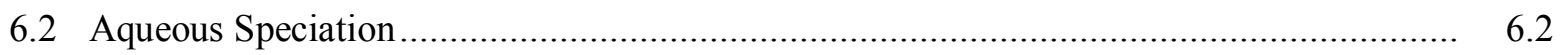

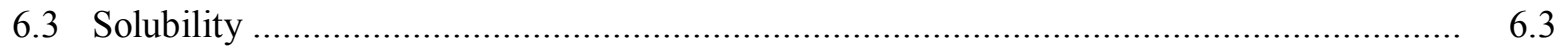

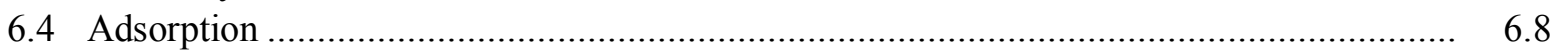




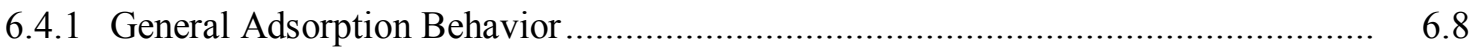

6.4.2 Surface Complexation Models ..................................................................... 6.10

6.4.3 Hanford Sediment U(VI) Adsorption Studies .............................................. 6.11

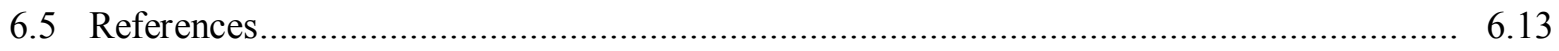

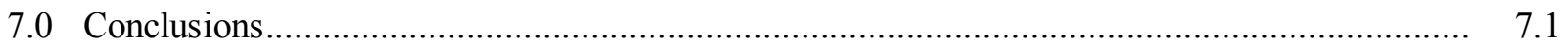

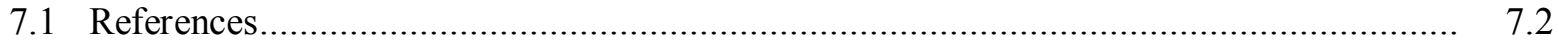

\section{Figures}

2.1. Eh-pH Diagram Showing Dominant Aqueous Species of Antimony ....................................... 2.3

2.2. Eh-pH Diagram Showing Dominant Aqueous Species of Antimony and Eh-pH Regions (Shaded Areas) Where Solubilities of Antimony Solids Have Been Exceeded.

2.3. Eh-pH Diagram Showing Dominant Aqueous Species of Antimony and Eh-pH Regions (Shaded Areas) Where Solubilities of Antimony Solids Have Been Exceeded........................... 2.6

3.1. Eh-pH Diagram Showing the Dominant Aqueous Complexes of Cobalt .................................. 3.2

3.2. Eh-pH Diagram Showing Dominant Aqueous Species of Cobalt and Eh-pH Region (Shaded Area) Where the Solubility of Cattierite Has Been Exceeded

3.3. Eh-pH Diagram Showing Dominant Aqueous Species of Cobalt and Eh-pH Region (Shaded Area) Where the Solubilities of Cobalt Solids Have Been Exceeded

4.1. Eh-pH Diagram Showing the Hydrolysis of Eu(III) and Eu(II) in the Absence of Other Complexing Ligands

4.2. Eh-pH Diagram Showing the Dominant Aqueous Complexes of Europium............................. 4.4

4.3. Eh-pH Diagram Showing the Dominant Aqueous Complexes of Europium ............................... 4.5

4.4. Concentrations (log molal) of $\mathrm{Eu}(\mathrm{III})$ Aqueous Complexes as a Function of $\mathrm{pH}$...................... 4.5

4.5. Eh-pH Diagram Showing the Stability Fields for the Dominant Europium Species at a Concentration of $10^{-6} \mathrm{~mol} / \mathrm{L}$ Total Dissolved Europium

5.1. Eh-pH Diagram Showing Dominant Aqueous Species of Technetium in the Absence of Dissolved Carbonate.

5.2. Eh-pH Diagram Showing Dominant Aqueous Species of Technetium and Eh-pH Regions (Shaded Areas) Where the Solubility of Solid Amorphous $\mathrm{TcO}_{2} \cdot 1.6 \mathrm{H}_{2} \mathrm{O}$ Has Been Exceeded ..... 5.6

6.1. Eh-pH Diagram Showing the Hydrolysis of U(VI) and U(IV) in the Absence of Other Complexing Ligands

6.2. Eh-pH Diagram Showing the Dominant Aqueous Complexes of Uranium....

6.3. Eh-pH Diagram Showing Dominant Aqueous Species of Uranium and Eh-pH Region (Shaded Area) Where the Solubility of Uraninite Has Been Exceeded.....

6.4. Distribution of $U(V I) K_{d}$ Values for Sediments and Single-Mineral Phases as a Function of $\mathrm{pH}$ in Carbonate-Containing Aqueous Solutions 
PNNL-14126

\section{Tables}

2.1. $\mathrm{K}_{\mathrm{d}}$ Values (mL/g) Measured by Legoux et al. (1992) for the Adsorption of Antimony on Natural Soil Measured at Oxic Conditions with an Initial Concentration of Dissolved Antimony of $1.6 \times 10^{-8} \mathrm{M}$.

2.2. Compositions of the Simulated High-Level Waste Solutions Used for ${ }^{125} \mathrm{Sb}$ Adsorption Experiments by Serne (1973, unpublished study)

2.3. Partition coefficient, $K_{d}$, values $(\mathrm{mL} / \mathrm{g})$ Measured for ${ }^{125} \mathrm{Sb}$ by Serne for Sediments

Contacting the Simulated High-Level Waste Solutions Listed in Table 2.2

3.1. $\mathrm{K}_{\mathrm{d}}$ values determined for ${ }^{60} \mathrm{Co}$ and ${ }^{60} \mathrm{Co}$ Complexed EDTA by Gee and Campbell (1980).

3.2. $K_{d}$ Values Ddetermined for ${ }^{60}$ Co by Cantrell and Serne (1993)

5.1. Technetium $K_{d}$ Values (ml/g) Measured by Kaplan et al. (1998b) for Hanford Trench AE-3 Sediment $(\mathrm{CEC}=6.4 \mathrm{meg} / 100 \mathrm{~g})$ Under Oxidizing Conditions. 5.8

7.1. Selected Chemical and Transport Properties of Contaminants 7.1 


\subsection{Introduction}

The concentrations of contaminants in sediment pore water and groundwater are controlled primarily by the amount of contaminant present at the source; rate of release from the source; hydrologic factors such as dispersion, advection, and dilution; and a number of geochemical processes including oxidation/reduction, aqueous speciation, adsorption/desorption, and precipitation/dissolution. To accurately predict contaminant transport through the subsurface, it is essential that the important geochemical processes affecting contaminant transport be identified and accurately described in a scientifically defensible manner.

In developing the Field Investigation Report for the Waste Management Area S-SX at the Hanford Site, ${ }^{137} \mathrm{Cs}$ was the only gamma emitting radionuclide of concern (Knepp 2002). However, in waste management area (WMA) B-BX-BY, the spectral gamma logging data identify seven gamma emitting radionuclides, ${ }^{137} \mathrm{Cs},{ }^{125} \mathrm{Sb},{ }^{152} \mathrm{Eu},{ }^{154} \mathrm{Eu},{ }^{60} \mathrm{Co},{ }^{235} \mathrm{U}$, and ${ }^{238} \mathrm{U}$ (DOE-GJPO 1998). The geochemical behavior of several of these radionuclides, ${ }^{125} \mathrm{Sb}$, and the two europium isotopes, have not been extensively investigated at the Hanford Site. This task was initiated to assure that our understanding of the geochemical processes affecting the environmental behavior of these radionuclides reflects the current state of knowledge.

A literature review was conducted to assess the important oxidation/reduction, aqueous speciation, solubility, and adsorption processes affecting the environmental behavior of antimony, cobalt, europium, technetium, and uranium in vadose zone sediments ${ }^{\mathrm{a}}$ with low-organic matter content in semi-arid environments such as those at the Hanford Site. Technetium-99 was included in this task because of its importance in the long-term risk calculations for the Hanford Site. The results of this literature review for antimony, cobalt, europium, technetium, and uranium are given in Chapters 2, 3, 4, 5, and 6, respectively.

Aqueous species distribution and Eh-pH (or Pourbaix) diagrams were calculated using geochemical modeling techniques to demonstrate the potential importance of certain redox states, aqueous species, and solids with respect to the geochemical behavior of the radionuclides of interest. The concentrations selected for the natural complexing ligands used to calculate the aqueous species distribution and Eh-pH diagrams are based on a composition for uncontaminated groundwater from the Hanford Site listed by Kaplan et al. (1996). We use this chemical composition for demonstration purposes simply as a proxy for soil pore water and groundwater across the Hanford Site. The calculations demonstrate what aqueous complexes and solubility controls might exist for a given radionuclide as a function of $\mathrm{pH}$, redox conditions, and the specified concentrations of each inorganic ligand. If the concentration of a complexing ligand, such as sulfate, is less for a site-specific groundwater compared to that used for our calculations, then aqueous complexes containing that contaminant and ligand may be less important for that water. Because thermodynamic data typically do not have the resolution to distinguish among

a The terms "sediment" and "soil" have particular meanings depending on one's technical discipline. For example, the term "sediment" is often reserved for transported and deposited particles derived from soil, rocks, or biological material. "Soil" is sometimes limited to referring to the top layer of the earth's surface, suitable for plant life. 
PNNL-14126

different isotopic forms of radionuclide-containing aqueous species or solids, geochemical modeling calculations do not provide any information on the distribution of the different radionuclide isotopes present in the aqueous, gaseous, or associated solid phases. However, in most situations, it is expected that most isotopes of a particular element will react in the same manner.

"Sorption" will be used in this report as a generic term devoid of mechanism to describe the partitioning of aqueous phase constituents to a solid phase. When a radionuclide is associated with a solid phase, it is commonly not known if the contaminant is adsorbed onto the surface of the solid, absorbed into the structure of the solid, precipitated as a three-dimensional molecular coating on the surface of the solid, or absorbed into organic matter. Sorption is frequently quantified by the partition (or distribution) coefficient $\left(\mathrm{K}_{\mathrm{d}}\right)$. The $\mathrm{K}_{\mathrm{d}}$ is defined as the ratio of the quantity of the adsorbate adsorbed per mass of solid to the amount of the adsorbate remaining in solution at equilibrium. The terms "partition coefficient" and "distribution coefficient" are used interchangeably in the literature for the $\mathrm{K}_{\mathrm{d}}$ linear isotherm sorption model.

\subsection{References}

DOE-GJPO (U.S. Department of Energy, Grand Junction Project Office). 1998. Vadose Zone Characterization Project at the Hanford Tank Farms: BX Tank Farm Report. GJO-HAN-19, U.S. Department of Energy, Grand Junction Project Office, Grand Junction, Colorado.

Kaplan DI, RJ Serne, AT Owen, J Conca, TW Wietsma, and TL Gervais. 1996. Radionuclide Adsorption Distribution Coefficients Measured in Hanford Sediments for the Low Level Waste Performance Assessment Project. PNNL-11485, Pacific Northwest Laboratory, Richland, Washington.

Knepp AJ. 2002. Field Investigation Report for Waste Management Area S-SX, RPP-7884, CH2M HILL Hanford Group, Inc., Richland, Washington. 
PNNL-14126

\subsection{Antimony}

Antimony ( $\mathrm{Sb}$ ) (atomic number 51) is a member of Group VA in the periodic classification of the elements. This element group also includes arsenic and phosphorous. Due to its larger atomic size, the coordination of $\mathrm{Sb}(\mathrm{V})$ is different from that of $\mathrm{As}(\mathrm{V})$ or $\mathrm{P}(\mathrm{V})$ (Baes and Mesmer 1976). Antimony-125 is the isotope of primary importance to waste disposal and site remediation activities at the Hanford Site. Antimony-125 is a fission product of ${ }^{235} \mathrm{U}$, and has a half life $\left(\mathrm{t}_{1 / 2}\right)$ of $2.7586 \mathrm{yr}$.

The environmental behavior of antimony has been reviewed to different degrees by Ames and Rai (1978), Rai et al. (1984, 1987), and Filella et al. (2002). Compared to most elements, little is known about the environmental behavior of antimony, especially with respect to its mobility in sediments and soils. Antimony is considered relatively mobile in the environment, especially under oxic conditions. Due to its high mobility, the antimony content of surficial geologic materials has been used as a prospecting guide for ore deposits containing antimony-bearing minerals, gold, silver, and some other metals (Rose et al. 1979). In addition to hydrothermal deposits, antimony can also be found in elevated concentrations in soils near anthropogenic sources, such as proximity to smelting plants, combustion of fossil fuels, and outfalls of sewage and fertilizer plants.

\subsection{Oxidation States}

Antimony can exist in several oxidation states, including $-3,0,+3$, and +5 (Baes and Mesmer 1976). Under natural environmental conditions, antimony exists in the +5 and +3 oxidation states. The +3 oxidation state of antimony is reported to be more toxic than its +5 state (Filella et al. 2002). In natural aqueous systems, $\mathrm{Sb}(\mathrm{V})$ and $\mathrm{Sb}(\mathrm{III})$ are the stable oxidation states under oxidizing and reducing conditions, respectively, based on equilibrium thermodynamic considerations. However, contrary to thermodynamic predictions, $\mathrm{Sb}(\mathrm{V})$ and $\mathrm{Sb}(\mathrm{III})$ have been found coexisting in natural aqueous systems. For example, $\mathrm{Sb}$ (III) has been detected under oxic conditions in different marine waters, fresh waters, groundwaters, and rain (Filella et al. 2002 and references cited therein). Researchers have suggested that the metastability of $\mathrm{Sb}$ (III) under oxic conditions may have resulted from biotic processes and/or a slow rate of $\mathrm{Sb}(\mathrm{III})$ oxidation. Antimony(V) has also been detected with $\mathrm{Sb}(\mathrm{III})$ in the presence of dissolved sulfide in some anoxic waters (Filella et al. 2002 and references cited therein). Proposed explanations for this observed metastability of $\mathrm{Sb}(\mathrm{V})$ include the transport of $\mathrm{Sb}(\mathrm{V})$ on sinking detritus from oxic waters, formation of $\mathrm{Sb}(\mathrm{V})$ thiocomplexes, or advection of oxic waters containing high $\mathrm{Sb}(\mathrm{V})$ concentrations, all coupled with a slow rate of $\mathrm{Sb}(\mathrm{V})$ reduction. Filella et al. (2002) also notes that the results of most speciation studies of inorganic antimony are based on analyses of $\mathrm{Sb}$ (III) and total antimony. The concentration of $\mathrm{Sb}(\mathrm{V})$ is then determined from the difference between total antimony and $\mathrm{Sb}(\mathrm{III})$.

\subsection{Aqueous Speciation}

Thermodynamic data for the aqueous species and solids of $\mathrm{Sb}(\mathrm{V})$ and $\mathrm{Sb}(\mathrm{III})$ are limited. Important sources of thermodynamic data checked for this review include Baes and Mesmer (1976), Wagman et al. (1982), Chase et al. (1985), and Smith et al. (1997). Sehmel (1989) published a compilation and evaluation of thermodynamic data for inorganic compounds of antimony. Most of the values selected by 
Sehmel (1989) for developing a database for antimony inorganic compounds were taken from Wagman et al. (1982) and Smith and Martell (1976), which is an earlier version of the extensive compilation by Smith et al. (1997).

Figure 2.1 is an Eh-pH diagram showing the dominant aqueous species of antimony. The diagram was calculated at $25^{\circ} \mathrm{C}$ using a concentration of $2.90 \times 10^{-10} \mathrm{mg} / \mathrm{L}\left(10^{-14.6} \mathrm{~mol} / \mathrm{L}\right)$ total dissolved antimony. This concentration corresponds to $300 \mathrm{pCi} / \mathrm{L}^{125} \mathrm{Sb}^{\mathrm{a}}$ The Eh-pH calculation also included the speciation of dissolved chloride, nitrate, sulfate, and carbonate that were entered at total concentrations of $22,1.7,108$, and $67.5 \mathrm{mg} / \mathrm{L}$, respectively. The concentrations selected for these ligands are based on a composition for uncontaminated groundwater from the Hanford Site listed by Kaplan et al. (1996).

Under oxic conditions, the hydrolytic species $\mathrm{Sb}(\mathrm{OH})_{6}{ }^{-}$is the dominant antimony aqueous species over an extended range of $\mathrm{pH}$ and $\mathrm{Eh}$ (Figure 2.1). This anionic species is dominant at $\mathrm{pH}$ values greater than approximately 2.5 , and from oxidizing to slightly reducing conditions. At moderately reducing conditions, the speciation is dominated by the $\mathrm{Sb}(\mathrm{III})$ hydrolytic species $\mathrm{Sb}(\mathrm{OH})_{2}{ }^{+}$at $\mathrm{pH}$ values less than $2, \mathrm{Sb}(\mathrm{OH})_{3}{ }^{\mathrm{o}}$ (aq) at $\mathrm{pH}$ values from 2 to 12 , and $\mathrm{Sb}(\mathrm{OH})_{4}{ }^{-}$at $\mathrm{pH}$ values greater 12 . At very reducing conditions in the presence of dissolved sulfide, the speciation of antimony may be dominated by $\mathrm{Sb}$ (III) sulfide species, such as $\mathrm{HSb}_{2} \mathrm{~S}_{4}{ }^{-}$and $\mathrm{Sb}_{2} \mathrm{~S}_{4}{ }^{-}$, at $\mathrm{pH}$ values less than and greater than 11.5, respectively.

An Eh-pH diagram similar to Figure 2.1 was calculated and diagrammed by Vink (1996). The dominant $\mathrm{Sb}(\mathrm{V})$ and $\mathrm{S}(\mathrm{III})$ aqueous species listed by Vink (1996) are in the form of oxyanions and not hydrolytic species. The common convention is to represent the hydrolytic species of antimony as hydroxide complexes [e.g., see Baes and Mesmer (1976)]. However, in many early publications and some recent papers, such as Vink (1996), these species are represented as oxyanions, analogous to those for arsenate/arsenite and phosphate. The hydroxide species and their associated thermodynamic values (e.g., $\Delta \mathrm{G}_{\mathrm{f}, 298}{ }^{\circ}$ ) are equivalent to their respective oxyanion forms plus the proper stoichiometric addition of water. For example, $\mathrm{Sb}^{\mathrm{III}}(\mathrm{OH})_{3}{ }^{\mathrm{o}}$ (aq) is equivalent to $\mathrm{HSb}^{\mathrm{III}} \mathrm{O}_{2}{ }^{\circ}$ (aq) plus $1 \mathrm{H}_{2} \mathrm{O}$ (liquid), and $\mathrm{Sb}^{\mathrm{V}}(\mathrm{OH})_{6}{ }^{-}$is equivalent to $\mathrm{Sb}^{\mathrm{V}} \mathrm{O}_{3}{ }^{-}$plus $3 \mathrm{H}_{2} \mathrm{O}$ (liquid).

At low concentrations of total dissolved antimony, the boundaries between the dominant aqueous species in Figure 2.1 are essentially independent of the antimony concentrations. However, $\mathrm{Sb}(\mathrm{V})$ may form a series of polynuclear species $\mathrm{Sb}_{12}(\mathrm{OH})_{64}{ }^{4-}, \mathrm{Sb}_{12}(\mathrm{OH})_{65}{ }^{5-}, \mathrm{Sb}_{12}(\mathrm{OH})_{66}{ }^{6-}$, and $\mathrm{Sb}_{12}(\mathrm{OH})_{67}{ }^{7-}$ at high concentrations of dissolved antimony $(>0.001 \mathrm{~m})$ under acidic conditions (Baes and Mesmer 1976). The stability constants derived by Baes and Mesmer (1976) from the results of Lefebvre and Maria (1963) indicate that the polynuclear species will dominate the aqueous speciation of $\mathrm{Sb}(\mathrm{V})$ at $\mathrm{pH}$ values less than 7 as the antimony concentration increases above $0.001 \mathrm{~m}$. Baes and Mesmer (1976) note that polymeric species of $\mathrm{Sb}$ (III) do not occur in significant amounts at $\mathrm{Sb}$ (III) concentrations less than $0.1 \mathrm{M}$.

a The concentration of $300 \mathrm{pCi} / \mathrm{L}$ is the interim drinking water standard (DWS) for ${ }^{125} \mathrm{Sb}$. It is based on the concentration of ${ }^{125} \mathrm{Sb}$ that is assumed to yield an annual dose equivalent of $4 \mathrm{mrem} / \mathrm{yr}$ DWS for beta particle emitters. 
PNNL-14126

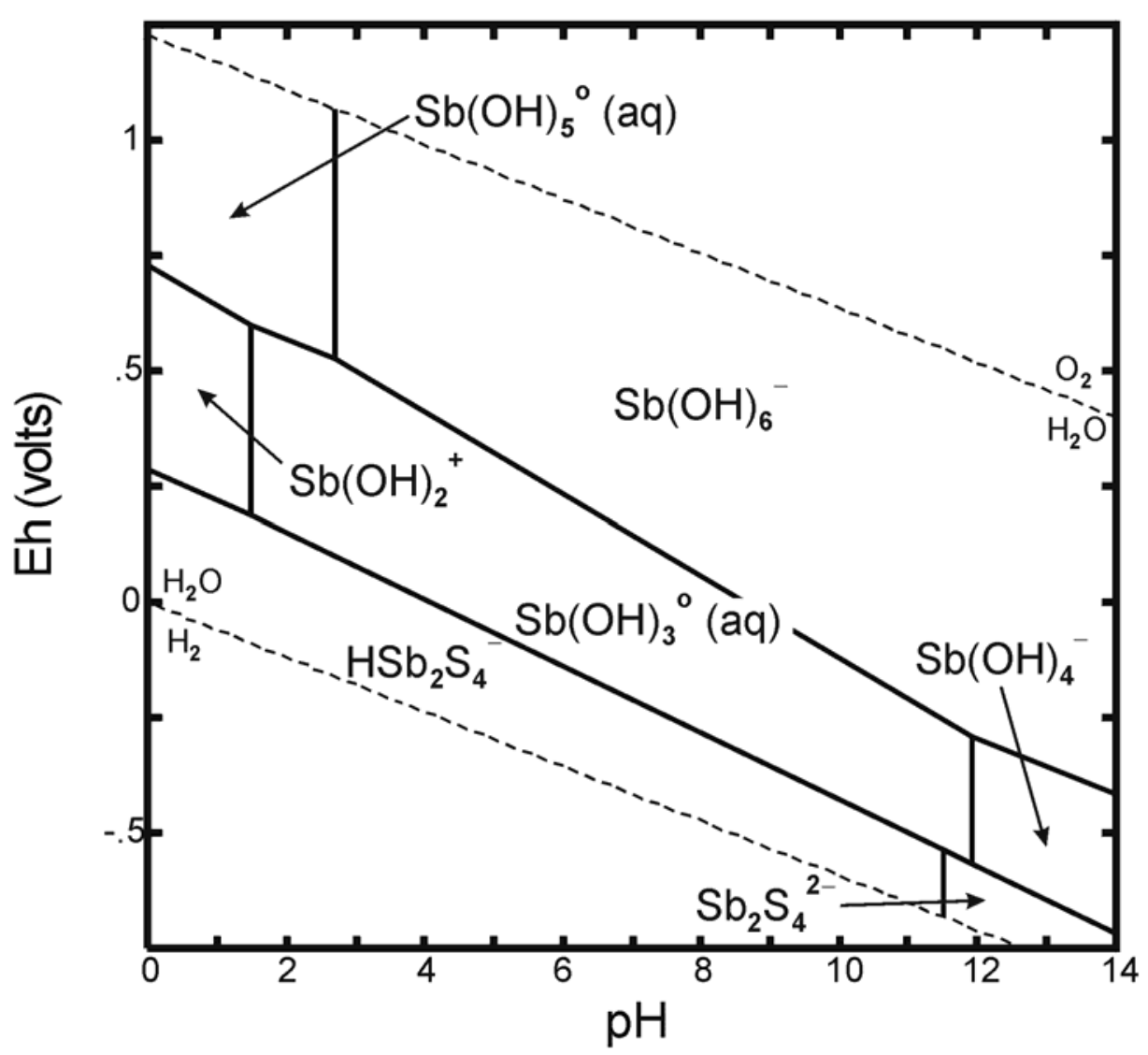

Figure 2.1. Eh-pH Diagram Showing Dominant Aqueous Species of Antimony [Diagram was calculated at $25^{\circ} \mathrm{C}$ and a concentration of $2.90 \times 10^{-10} \mathrm{mg} / \mathrm{L}\left(10^{-14.6} \mathrm{~mol} / \mathrm{L}\right)$ total dissolved antimony.]

Antimony is closely associated with several types of ore deposits (Rose et al. 1979). Chloride and sulfide complexation of antimony, especially $\mathrm{Sb}$ (III), has therefore received some study due to the role of such species in the hydrothermal transport of antimony and formation of ore deposits [for example, see Helz et al. (2002), Mosselmans et al. (2000), Sherman et al. (2000), Oekers et al. (1998), Wood (1989), and others]. Under reducing conditions, the aqueous speciation of $\mathrm{Sb}$ (III) will be dominated by complexes, such as $\mathrm{SbCl}^{2+}, \mathrm{SbCl}_{2}{ }^{+} \mathrm{SbCl}_{3}{ }^{\mathrm{o}}$ (aq), and $\mathrm{SbCl}_{4}{ }^{-}$, in chloride-rich, acidic aqueous solutions at low temperatures (Oelkers et al. (1998 and reference therein). Sulfide species, such as $\mathrm{HSb}_{2} \mathrm{~S}_{4}{ }^{-}$and $\mathrm{Sb}_{2} \mathrm{~S}_{4}{ }^{2-}$ (Figure 2.1), are dominant in the presence of dissolved sulfide at low chloride concentrations and low temperatures. Recent studies by Helz et al. (2002), Mosselmans et al. (2000) and Sherman et al. (2000) also indicate the presence of $\mathrm{Sb}(\mathrm{V})$ sulfide complexes under reducing conditions. Mosselmans et al. (2000) proposed that dissolved $\mathrm{HS}^{-}$promoted the oxidation of $\mathrm{Sb}$ (III) to $\mathrm{Sb}(\mathrm{V})$ to form species, such as $\mathrm{Sb}^{\mathrm{V}} \mathrm{S}_{4}{ }^{3-}$, via the following reversible reaction:

$$
(\mathrm{y}+1-\mathrm{x}) \mathrm{H}^{+}+\mathrm{HS}^{-}+\mathrm{H}_{\mathrm{x}} \mathrm{Sb}^{\mathrm{III}} \mathrm{S}_{3}{ }^{(\mathrm{x}-3)} \Leftrightarrow \mathrm{H}_{\mathrm{y}} \mathrm{Sb}^{\mathrm{V}} \mathrm{S}_{4}{ }^{(\mathrm{y}-3)}+\mathrm{H}_{2}(\mathrm{~g})
$$


At a given concentration of $\mathrm{HS}^{-}$, the above equation implies that the $\mathrm{Sb}$ (III) sulfide species will dominate over the $\mathrm{Sb}(\mathrm{V})$ sulfide species at lower $\mathrm{H}^{+}$concentrations (i.e., higher $\mathrm{pH}$ values) (Mosselmans et al. 2000). The X-ray absorption fine structure (EXAFS) spectroscopy measurements by Sherman et al. (2000), however, indicate that the aqueous species $\mathrm{Sb}(\mathrm{HS})_{4}{ }^{+}$will dominate in basic $\mathrm{Sb}(\mathrm{V})-(\mathrm{H}) \mathrm{S}$ solutions at temperatures less than approximately $150^{\circ} \mathrm{C}$. The authors of these studies suggest that these results may help to explain the observed presence of $\mathrm{Sb}(\mathrm{V})$ under redox conditions where $\mathrm{Sb}(\mathrm{III})$ should be the stable oxidation state based on equilibrium thermodynamic conditions.

Methylated antimony species have also been detected in some marine waters and river waters, but they usually comprise $10 \%$ or less of the total dissolved antimony in these waters (Fillella et al. 2002). Recent laboratory studies by Gürleyük et al. (1997) and Jenkins et al. (1998a, b) have demonstrated the production of gaseous trimethylantimony $\left[\left(\mathrm{CH}_{3}\right)_{3} \mathrm{~S}\right]$ by microorganisms. It has been known for some time that several elements surrounding antimony in the periodic table, such as arsenic, selenium, and lead, can be affected biomethylation reactions.

\subsection{Solubility Limits}

Over 240 antimony-bearing minerals are known. ${ }^{a}$ Many of these minerals are sulfides and antimonides, and form in high-sulfide, reducing environments such as hydrothermal ore deposits. Two of the more common antimony-containing minerals found in hydrothermal deposits include stibnite $\left(\mathrm{Sb}_{2} \mathrm{~S}_{3}\right)$ or kermesite $\left(\mathrm{Sb}_{2} \mathrm{~S}_{2} \mathrm{O}\right)$. Antimony often occurs in minerals in solid solution with arsenic [e.g., guettardite $\left.\mathrm{Pb}(\mathrm{Sb}, \mathrm{As})_{2} \mathrm{~S}_{4}\right]$ and/or with its other neighboring elements in the periodic table, such as bismuth, tellurium, and lead. Antimony can also exist in minerals in more than one oxidation state, such as cervantite $\left[\mathrm{Sb}^{\mathrm{III}} \mathrm{Sb}^{\mathrm{V}} \mathrm{O}_{4}\right]$ and paradocrasite $\left[\mathrm{Sb}_{2}^{\mathrm{III}}\left(\mathrm{Sb}^{-\mathrm{III}}, \mathrm{As}\right)_{2}\right]$.

Antimony, especially under oxic conditions, is very soluble (Rai et al. 1984). The concentrations of antimony in most soils are not likely limited by solubility considerations. Under reducing conditions, antimony concentrations may be limited by the solubility of antimony sulfides, such as stibnite. The availability of thermodynamic data is limited to only a few antimony solids, such as elemental $\mathrm{Sb}$, $\mathrm{Sb}(\mathrm{OH})_{3}, \mathrm{Sb}_{2} \mathrm{O}_{3}$ (valentinite, senarmontite), $\mathrm{Sb}_{2} \mathrm{O}_{4}$ (cervantite), $\mathrm{Sb}_{2} \mathrm{O}_{5}, \mathrm{Sb}_{4} \mathrm{O}_{6}, \mathrm{Sb}_{2} \mathrm{~S}_{3}$ (stibnite), and a few others. None of these antimony solids calculate to be oversaturated at the conditions $\left[2.90 \times 10^{-10} \mathrm{mg} / \mathrm{L}\right.$ $\left(10^{-14.6} \mathrm{~mol} / \mathrm{L}\right)$ total dissolved antimony] used to calculate Figure 2.1. The concentration of total dissolved antimony has to be increased to approximately $10^{-9} \mathrm{~mol} / \mathrm{L}(0.000125 \mathrm{mg} / \mathrm{L})$ before the solubility of any of these solids is exceeded. Figure 2.2 was calculated at the same conditions as Figure 2.1, except for an increase in antimony concentration to $10^{-9} \mathrm{~mol} / \mathrm{L}$. The diagram shows that the solubilities (shaded areas in Figure 2.2) of $\mathrm{Sb}_{2} \mathrm{O}_{4}$ and $\mathrm{Sb}_{2} \mathrm{~S}_{3}$ are exceeded at acidic $\mathrm{pH}$ values under reducing conditions.

Increasing the concentrations of dissolved antimony expands these Eh-pH regions of oversaturation to higher $\mathrm{pH}$ values, and in the case of $\mathrm{Sb}_{2} \mathrm{O}_{4}$, to more oxic conditions. For example, Figure 2.3 was calculated at a concentration of $10^{-7} \mathrm{~mol} / \mathrm{L}(0.0125 \mathrm{mg} / \mathrm{L})$ total dissolved antimony and the same conditions as Figure 2.1. This figure clearly shows the expanded Eh-pH region for the solubility for

a Statement based on a search of Web-based mineralogical database at http://webmineral.com/chemical.shtml 
$\mathrm{Sb}_{2} \mathrm{O}_{4}$. Moreover, the available thermodynamic data indicates that the solubility of solid $\mathrm{Sb}(\mathrm{OH})_{3}$ is exceeded at $10^{-7} \mathrm{~mol} / \mathrm{L}$ dissolved antimony for $\mathrm{pH}$ values from approximately 1.5 to 12 under moderately reducing conditions. Thermodynamic calculations do not identify any potential solubility control for dissolved $\mathrm{Sb}(\mathrm{V})$ at basic $\mathrm{pH}$ conditions under oxic conditions. However, as noted previously, the thermodynamic data for antimony aqueous species and solids are limited. Solubility calculations based on such values are likely to be qualitative at best.

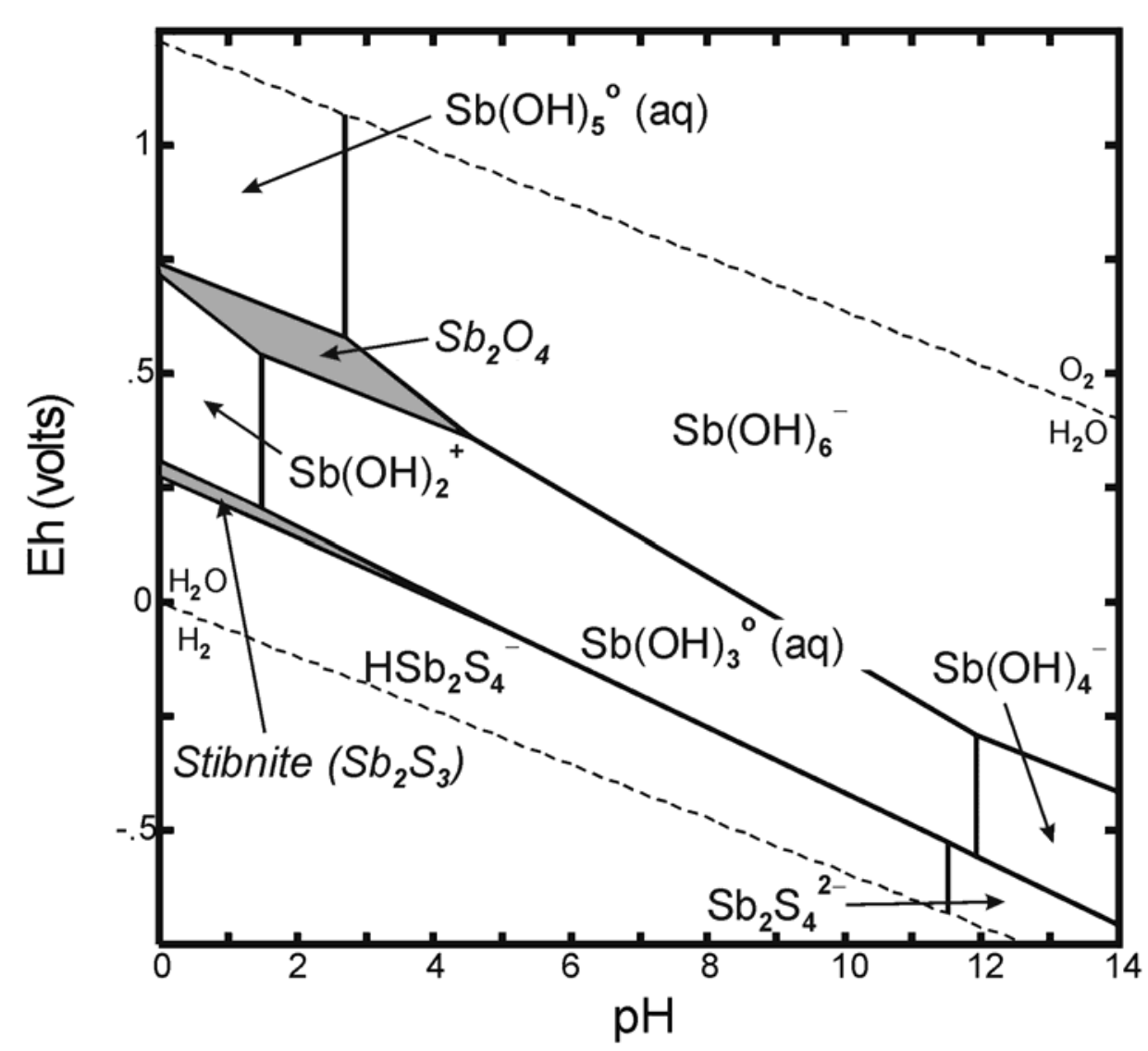

Figure 2.2. Eh-pH Diagram Showing Dominant Aqueous Species of Antimony and Eh-pH Regions (Shaded Areas) Where Solubilities of Antimony Solids Have Been Exceeded [Diagram was calculated at $25^{\circ} \mathrm{C}$ and a concentration of $10^{-9} \mathrm{~mol} / \mathrm{L}$ total dissolved antimony.] 
PNNL-14126

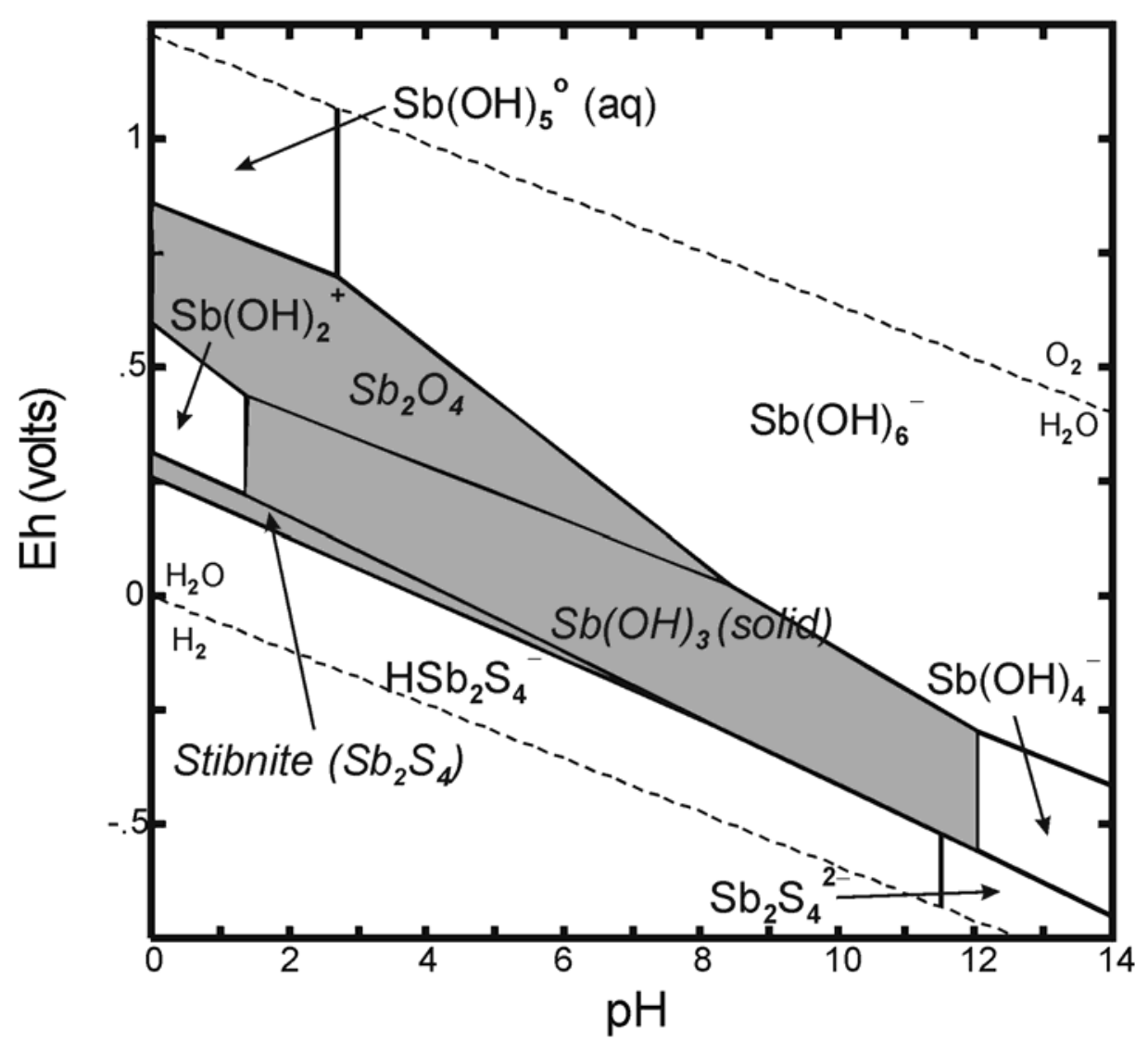

Figure 2.3. Eh-pH Diagram Showing Dominant Aqueous Species of Antimony and Eh-pH Regions (Shaded Areas) Where Solubilities of Antimony Solids Have Been Exceeded [Diagram calculated at $25^{\circ} \mathrm{C}$ and a concentration of $10^{-7} \mathrm{~mol} / \mathrm{L}$ total dissolved antimony.]

\subsection{Adsorption}

Very little is known about the adsorption/desorption behavior of $\mathrm{Sb}(\mathrm{V})$ or $\mathrm{Sb}(\mathrm{III})$. However, the concentrations of antimony in soils and sediments are likely controlled by adsorption reactions [e.g., Brannon and Patrick (1985) and Crecelius et al. (1975)]. Crecelius et al. (1975) have shown, for example, that more than half of the total antimony in "non-contaminated" Puget Sound sediments was bound to extractable iron and aluminum compounds. Some general trends can be assumed for the adsorption of antimony. Because adsorption of anions is coupled with a release of $\mathrm{OH}^{-}$ions, anion adsorption is greatest at low $\mathrm{pH}$ where mineral surfaces are positively charged and decreases with increasing pH (Schindler and Stumm 1987). On the other hand, the adsorption of cations is coupled with a release of $\mathrm{H}^{+}$ions. Therefore, cation adsorption is greatest at high $\mathrm{pH}$ where mineral surfaces are negatively charged and decreases with decreasing $\mathrm{pH}$.

Because dissolved $\mathrm{Sb}(\mathrm{V})$ is present primarily as the anionic hydrolytic species $\mathrm{Sb}(\mathrm{OH})_{6}{ }_{6}^{-}$(Figure 2.1) over almost the entire $\mathrm{pH}$ range, the adsorption of $\mathrm{Sb}(\mathrm{V})$ to hydroxide and oxide mineral surfaces should be limited to negligible as $\mathrm{pH}$ increases from circumneutral to highly basic $\mathrm{pH}$ values. Under these 
conditions, antimony should be highly mobile in the geochemical environment. If the speciation calculations are valid, $\mathrm{Sb}(\mathrm{III})$ present as the anions $\mathrm{Sb}(\mathrm{OH})_{4}{ }^{-}$or $\mathrm{Sb}_{2} \mathrm{~S}_{4}{ }^{2-}$ at $\mathrm{pH}$ values greater than 11 under reducing conditions (see Figure 2.1) should also exhibit negligible adsorption to hydroxide and oxide mineral surfaces, and thus be highly mobile in the environment. However, at acidic $\mathrm{pH}$ conditions, the adsorption of $\mathrm{Sb}(\mathrm{V})$ may be significant to mineral surfaces. Only a couple of laboratory adsorption studies for antimony on soils and sediments were identified during the course of this review. These studies support the adsorption behavior suggested above for $\mathrm{Sb}(\mathrm{V})$.

Legoux et al. (1992) measured partition coefficient, $K_{d}$, values for the adsorption of antimony on four samples of natural soil material taken as a function of depth (site not specified). The soil samples were designated as A, B, C, and D, and taken at depths of 7.8-7.9, 9.65-9.85, 11.1-11.25, and 12-12.2 m, respectively. The sand/clay soil samples contained predominately quartz; lesser amounts of the clay minerals illite, glauconite, smectite, kaolinite, palygorskite; and trace amounts of sepiolite and chlorite. The $K_{d}$ values were determined using static batch equilibration experiments in which the soil samples were equilibrated with a synthetic site water solution that was reacted with the soils prior to the addition of the antimony spike. The $\mathrm{pH}$ of the equilibrated waters was adjusted with $\mathrm{LiOH}$ solution. Legoux et al. (1992) did not specify the redox conditions for their experiments. However, it is assumed that the measurements were completed under oxidic conditions because the authors did not mention any precautions that were used to minimize or exclude oxygen from their experiments. The $\mathrm{K}_{\mathrm{d}}$ values measured for the soil samples by Legoux et al. (1992) are listed in Table 2.1. Their $\mathrm{K}_{\mathrm{d}}$ values clearly show that the adsorption of antimony decreases with increasing $\mathrm{pH}$. This trend is consistent for dissolved constituents that are present predominately as anions.

Results of an unpublished, antimony adsorption study ${ }^{\text {a }}$ by R. J. Serne (1973, Pacific Northwest National Laboratory) indicate that the adsorption of antimony is very low in Hanford soils contacting high-salt, high pH solutions (i.e., simulated single-shell tank liquors). Serne equilibrated several Hanford sediments with simulated neutralized, high-level waste solutions containing ${ }^{125} \mathrm{Sb}$. The compositions of the simulated high-level waste solutions are listed in Table 2.2. The partition coefficient, $\mathrm{K}_{\mathrm{d}}$, values measured by Serne for the five solutions are listed in Table 2.3. The $\mathrm{K}_{\mathrm{d}}$ values measured for solutions I, II, and V show very little to essentially no adsorption of ${ }^{125} \mathrm{Sb}$. The large ${ }^{125} \mathrm{Sb}_{\mathrm{d}}$ values measured for sediments contacting the high-calcium solutions III and IV are up to three orders of magnitude greater than those for the other three solutions. Serne proposed that at these high $\mathrm{pH}$ conditions and high dissolved calcium concentrations, the absorption of $\mathrm{CO}_{2}$ from air resulted in the precipitation of calcite $\left(\mathrm{CaCO}_{3}\right)$. This precipitation reaction in turn co-precipitated a portion of the dissolved antimony, and resulted in the large $\mathrm{K}_{\mathrm{d}}$ values.

\footnotetext{
a The unpublished antimony adsorption study by R. J. Serne (Pacific Northwest National Laboratory) is described in Ames and Rai (1978).
} 
Table 2.1. $K_{d}$ Values (mL/g) Measured by Legoux et al. (1992) for the Adsorption of Antimony on Natural Soil Measured at Oxic Conditions with an Initial Concentration of Dissolved Antimony of $1.6 \times 10^{-8} \mathrm{M}$

\begin{tabular}{||l|c|c|c|c||}
\hline \multirow{2}{*}{} & \multicolumn{4}{|c||}{ Soil Sample } \\
\cline { 2 - 5 } & A & B & C & D \\
\hline \hline $\mathrm{pH}$ & 7.6 & 5.9 & 6.6 & 8.0 \\
\hline $\mathrm{K}_{\mathrm{d}}(\mathrm{mL} / \mathrm{g})$ & $3.76 \pm 0.17$ & $122 \pm 10$ & $69 \pm 4.5$ & $2 \pm 0.28$ \\
\hline
\end{tabular}

Table 2.2. Compositions of the Simulated High-Level Waste Solutions Used for ${ }^{125} \mathrm{Sb}$ Adsorption Experiments by Serne (1973, unpublished study)

\begin{tabular}{|c|c|c|c|c|c|}
\hline \multirow{3}{*}{ Constituent } & \multicolumn{5}{|c|}{ Solution ID } \\
\hline & $\mathbf{I}$ & II & III & IV & $\mathbf{V}$ \\
\hline & \multicolumn{5}{|c|}{ Concentrations in Molarity (M) } \\
\hline $\mathrm{NaNO}_{3}$ & 1.0 & 4.0 & 1.0 & 4.0 & 0.6 \\
\hline $\mathrm{NaNO}_{2}$ & & & & & 1.18 \\
\hline $\mathrm{Na}_{2} \mathrm{CO}_{3}$ & & & & & 0.79 \\
\hline $\mathrm{Ca}\left(\mathrm{NO}_{3}\right)_{2}$ & 0.002 & 0.002 & 3.5 & 3.5 & 0.002 \\
\hline $\mathrm{NH}_{4} \mathrm{NO}_{3}$ & 0.65 & 0.65 & 0.65 & 0.65 & 0.15 \\
\hline$\left(\mathrm{NH}_{4}\right)_{2} \mathrm{SO}_{4}$ & & & & & 0.25 \\
\hline $\mathrm{KNO}_{3}$ & 0.025 & 0.025 & 0.025 & 0.025 & 0.01 \\
\hline $\mathrm{pH}$ & 12 & 12 & 12 & 2 & 12 \\
\hline
\end{tabular}

Table 2.3. Partition coefficient, $K_{d}$, values $\left(\mathrm{mL} / \mathrm{g}\right.$ ) Measured for ${ }^{125} \mathrm{Sb}$ by Serne for Sediments Contacting the Simulated High-Level Waste Solutions Listed in Table 2.2

\begin{tabular}{|l|c|c|c|c|c||}
\hline \multirow{2}{*}{ Sediment Type } & \multicolumn{5}{|c|}{ Solution ID } \\
\cline { 2 - 7 } & I & II & III & IV & V \\
\hline \hline Silt & 0.036 & 0.548 & 79.7 & 122.8 & 0.081 \\
\hline Gravelly Sand & 0.0 & 0.483 & 81.4 & 71.1 & 0.045 \\
\hline Sand & 0.0 & 0.491 & 55.4 & 109.0 & 0.055 \\
\hline Silty Sand & 1.27 & 2.09 & 83.7 & 43.6 & 0.228 \\
\hline Caliche & 0.73 & 0.56 & 15.8 & 14.7 & 0.140 \\
\hline Silty Sand & 0.65 & 0.40 & 15.3 & 24.1 & 0.140 \\
\hline
\end{tabular}




\begin{tabular}{|l|l|l|l|l|l|}
\hline Gravel & 1.28 & 1.19 & 17.6 & 24.0 & 0.180 \\
\hline
\end{tabular}

Adsorption of $\mathrm{Sb}(\mathrm{III})$ to iron and manganese oxyhydroxides can oxidize $\mathrm{Sb}(\mathrm{III})$ to $\mathrm{Sb}(\mathrm{V})$. Belzile et al. (2001) studied the oxidation of $\mathrm{Sb}$ (III) at different $\mathrm{pH}$ values using amorphous forms of natural and synthetic iron oxyhydroxides and synthetic manganese oxyhydroxide solids. Their differential pulse adsorptive stripping voltametry (DPACSV) measurements indicated that oxidation of $\mathrm{Sb}(\mathrm{III})$ to $\mathrm{Sb}(\mathrm{V})$ was always rapid and complete with a few days. Belzile et al. (2001) proposed that this reaction process may be important to the remediation of antimony, because $\mathrm{Sb}(\mathrm{III})$ is significantly more toxic than $\mathrm{Sb}(\mathrm{V})$.

\subsection{References}

Ames LL and D Rai. 1978. Radionuclide Interactions with Soil and Rock Media. Volume 1: Processes Influencing Radionuclide Mobility and Retention, Element Chemistry and Geochemistry, and Conclusions and Evaluations. EPA 520/6-78-007-a, U.S. Environmental Protection Agency, Las Vegas, Nevada.

Baes CF, Jr and RF Mesmer. 1976. The Hydrolysis of Cations. John Wiley and Sons, New York, New York.

Belzile N, Y-W Chen, and Z Wang. 2001. “Oxidation of Antimony(III) by Amorphous Iron and Manganese Oxyhydroxides.” Chemical Geology, 174:379-387.

Brannon JM, and WH Patrick, Jr. 1985. "Fixation and Mobilization of Antimony in Sediments." Environmental Pollution (Series B), 9:107-126.

Chase MW, Jr., CA Davis, JR Downey, Jr., DJ Frurip, RA McDonald, and AN Syverud. 1985. "JANAF Thermochemical Tables. Third Edition. Part II, Cr-Zr." Journal of Physical and Chemical Reference Data (Supplement No. 1), 14:927-1856.

Crecelius EA, MH Bothner, and R Carpenter. 1975. "Geochemistries of Arsenic, Antimony, Mercury, and Related Elements in Sediments of Puget Sound." Environmental Science and Technology, 9:325-333.

Filella M, N Belzile, and Y-W Chen. 2002. "Antimony in the Environment: A Review Focused on Natural Waters. I. Occurrence.” Earth-Science Reviews, 57:125-176.

Gürleyük H, V Van Fleet Stalder, and TG Chasteen. 1997. "Confirmation of the Biomethylation of Antimony Compounds.” Applied Organometallic Chemistry, 11:471-483.

Helz GR, MS Valerio, and NE Capps. 2002. “Antimony Speciation in Alkaline Sulfide Solutions: Roles of Zerovalent Sulfur.” Environmental Science and Technology, 36:943-948.

Jenkins RO, PJ Craig, W Goessler, D Miller, N Ostah, and KJ Irgolic. 1998a. "Biomethylation of Inorganic Antimony Compounds by an Aerobic Fungus: Scopulariopsis brevicaulis." Environmental Science and Technology, 32:882-885. 
PNNL-14126

Jenkins RO, PJ Craig, DP Miller, LCAM Stoop, N Ostah, and TA Morris. 1998b. “Antimony Biomethylation by Mixed Cultures of Micro-organisms under Anaerobic Conditions." Applied Organometallic Chemistry, 12:449-455.

Kaplan DI, RJ Serne, AT Owen, J Conca, TW Wietsma, and TL Gervais. 1996. Radionuclide Adsorption Distribution Coefficients Measured in Hanford Sediments for the Low Level Waste Performance Assessment Project. PNNL-11485, Pacific Northwest Laboratory, Richland, Washington.

LeFebvre J and H Maria. 1963. "Etude des Equilibres dans les Solutions Recentes des Polyantimoniates." Comptes Rendus Hebdomadaires des Seances d l Academie des Sciences, 256:3121-3124.

Legoux Y, G Blain, R Guillaumont, G Ouzounian, L Brillard, and M Hussonnois. 1992. " $K_{d}$ Measurements of Activation, Fission and heavy Elements in Water/Solid Phase Systems." Radiochimica Acta, 58/59:211-218.

Mosselmans JFW, GR Helz, RAD Pattrick, JM Charnock, and DJ Vaughan. 2000. "A Study of Speciation of Sb of Bisulfide Solutions by X-ray Absorption Spectroscopy." Applied Geochemistry, 15:879-889.

Oelkers EH, DM Sherman, KV Ragnarsdottir, and C Collins. 1998. "An EXAFS Spectroscopic Study of Aqueous Antimony(III)-Chloride Complexation at Temperatures from 25 to $250^{\circ} \mathrm{C}$." Chemical Geology, 151:21-27.

Rai D, JM Zachara, AP Schwab, RL Schmidt, DC Girvin, and JE Rogers. 1984. Chemical Attenuation Rates, Coefficients, and Constants in Leachate Migration. Volume 1: A Critical Review. EA-3356, Electric Power Research Institute, Palo Alto, California.

Rai D, CC Ainsworth, LE Eary, SV Mattigod, and DR Jackson. 1987. Inorganic and Organic Constituents in Fossil Fuel Combustion Residues. Volume 1: A Critical Review. EA-5176, Volume 1, Electric Power Research Institute, Palo Alto, California.

Rose AW, HE Hawkes, and JS Webb. 1979. Geochemistry in Mineral Exploration. Academic Press, Second Edition, New York, New York.

Schindler PW, and W Stumm. 1987. "The Surface Chemistry of Oxides, Hydroxides, and Oxide Minerals." In Aquatic Surface Chemistry. Chemical Processes at the Particle-Water Interface, W Stumm (ed.), pp. 83-110, John Wiley and Sons, New York, New York.

Sehmel GA 1989. Cyanide and Antimony Thermodynamic Database for the Aqueous Species and Solids for the EPA-MINTEQ Geochemical Code. PNL-6835, Pacific Northwest Laboratory, Richland, Washington.

Sherman DM, KV Ragnarsdottir, and EH Oelkers. 2000. “Antimony Transport in Hydrothermal Solutions: An EXAFS Study of Antimony(V) Complexation in Alkaline Sulfide and Sulfide-Chloride Brines at Temperatures from $25^{\circ} \mathrm{C}$ to $300^{\circ} \mathrm{C}$ at $\mathrm{P}_{\text {sat." }}$ Chemical Geology, 167:161-167. 
Smith RM, and AM Martell. 1976. Critical Stability Constants, Volume 4: Inorganic Complexes. Plenum Press, New York, New York.

Smith RM, AE Martell, and RJ Motekaitis. 1997. NIST Critically Selected Stability Constants of Metal Complexes Database. Version 4.0. NIST Standard Reference Database 46, National Institute of Standards and Technology, Gaithersburg, Maryland. (includes personal computer software database)

Vink BW. 1996. "Stability Relations of Antimony and Arsenic Compounds in the Light of Revised and Extended Eh-pH Diagrams." Chemical Geology, 130:21-30.

Wagman DD, WH Evans, VB Parker, RH Shumm, I Halow, SM Bailey, KL Churney, and RL Nuttall. 1982. "The NBS Tables of Chemical Thermodynamic Properties. Selected Values for Inorganic and $\mathrm{C}_{1}$ and $\mathrm{C}_{2}$ Organic Substances in SI Units." Journal of Physical and Chemical Reference Data 11(Supplement No. 2):1-392.

Wood SA. 1989. "Raman Spectroscopic Determination of the Speciation of Ore Metals in Hydrothermal Solutions. I. Speciation of Antimony in Alkaline Sulfide Solutions at $25^{\circ} \mathrm{C}$." Geochimica et Cosmochimica Acta, 53:237-244. 
PNNL-14126

\subsection{Cobalt}

Cobalt (Co) (atomic number 27) is a transition metal in Group VIII of the periodic classification of the elements. Group VIII also includes the elements iron and nickel. Cobalt-60 is the isotope of primary importance to waste disposal and site remediation. Cobalt-60 is an activation product of stable ${ }^{59} \mathrm{Co}$, which is a common impurity in zircaloy and aluminum fuel cladding and in uranium metal fuel (Harmsen and Schulz 1998). Cobalt-60 has a half life $\left(\mathrm{t}_{1 / 2}\right)$ of 1925.1 days ( $\left.\sim 5.3 \mathrm{yrs}\right)$.

Ames and Rai (1978), Hamilton (1994), and others have reviewed the environmental geochemistry of cobalt. The review by Hamilton (1994) is particularly noteworthy in that it discusses the geochemical behavior of cobalt in terrestrial, aquatic, and atmospheric systems, and its uptake by plants, animals, and man and the associated health effects. The geochemical behavior of cobalt generally follows that of the iron-manganese system, and its concentration in sediment and soil systems is mainly controlled by adsorption and coprecipitation reactions with manganese and iron oxide minerals (Hem 1985). Cobalt is "typically" regarded as being moderately to highly adsorbed by minerals in most terrestrial systems in the absence of organic ligands. Because ${ }^{60} \mathrm{Co}$ readily adsorbs to minerals and has a short half life relative to those of other radionuclides of environmental concern, the mobility of ${ }^{60} \mathrm{Co}$ should be limited in soil pore waters and groundwaters, and its detection in soil and sediment systems should be confined to near the areas of its release.

However, enhanced migration of ${ }^{60} \mathrm{Co}$ has been reported at several sites where low-level radionuclides have been released to the environment, such as the Chalk River Nuclear Laboratories in Canada (Killey et al. 1984); Hanford Site (Fruchter et al. 1984, 1985; Jones et al. 1988); and Oak Ridge National Laboratory (ORNL), Tennessee (Means et al. 1976, 1978a; Olsen et al. 1986). The increased migration of ${ }^{60} \mathrm{Co}$ at these sites was determined to be due to the presence of organic chelating agents, such as ethylenediaminetetraacetic acid (EDTA) (Killey et al. 1984; Fruchter et al. 1984, 1985; Jones et al. 1988; Means et al. 1976, 1978a; Olsen et al. 1986).

\subsection{Oxidation States}

Cobalt can exist in the +2 and +3 oxidation states (Baes and Mesmer 1976). Under most geochemical conditions, $\mathrm{Co}(\mathrm{II})$ is the stable valence state in water. Cobalt(III) is a strong oxidizing agent, and is not thermodynamically stable and decomposes under Eh-pH conditions common for most natural waters. However, the presence of certain complexing ligands, such as EDTA and $\mathrm{NH}_{3}$, can stabilize the +3 oxidation state of cobalt relative to reduction and allow it to persist in aqueous solutions (Section 3.4).

\subsection{Aqueous Speciation}

Figure 3.1 shows the Eh-pH diagram for the dominant cobalt aqueous species calculated for total concentrations of dissolved chloride, nitrate, sulfate, and carbonate of $22,1.7,108$, and $67.5 \mathrm{mg} / \mathrm{L}$, respectively. The concentrations selected for these ligands are based on a composition for uncontaminated groundwater from the Hanford Site listed by Kaplan et al. (1996). The Eh-pH diagram was calculated using a total concentration of $10^{-14.8} \mathrm{~mol} / \mathrm{L}$ dissolved cobalt, which corresponds to 
$100 \mathrm{pCi} / \mathrm{L}$ and the interim drinking water standard (DWS) for ${ }^{60} \mathrm{Co}$. Figure 3.1 is consistent with that presented by Glasby and Schulz (1999).

All of the dominant aqueous species shown in Figure 3.1 contain cobalt in the +2 oxidation state. No stability field is predicted from thermodynamic considerations for $\mathrm{Co}$ (III) aqueous species within the Eh-pH stability limits (area between dashed lines in Figure 3.1) for water. Under oxidizing and moderately reducing conditions, the dominant cobalt aqueous species predicted at $\mathrm{pH}$ values less than 9.5 is the uncomplexed ion $\mathrm{Co}^{2+}$. At $\mathrm{pH}$ values between 9.5 and 13.5 and at greater than 13.5, the hydrolytic species $\mathrm{Co}(\mathrm{OH})_{2}{ }^{\mathrm{o}}$ (aq) and $\mathrm{Co}(\mathrm{OH})_{4}{ }^{2-}$ are predicted to be dominant. Under the conditions of these calculations, cobalt does not appear to form any important complexes with dissolved chloride, nitrate, sulfate, and carbonate. Under very reducing conditions in the presence of dissolved sulfide, Co(II) bisulfide species, such as $\mathrm{Co}(\mathrm{HS})_{2}{ }^{\mathrm{o}}$ (aq), likely dominate the aqueous speciation of cobalt.

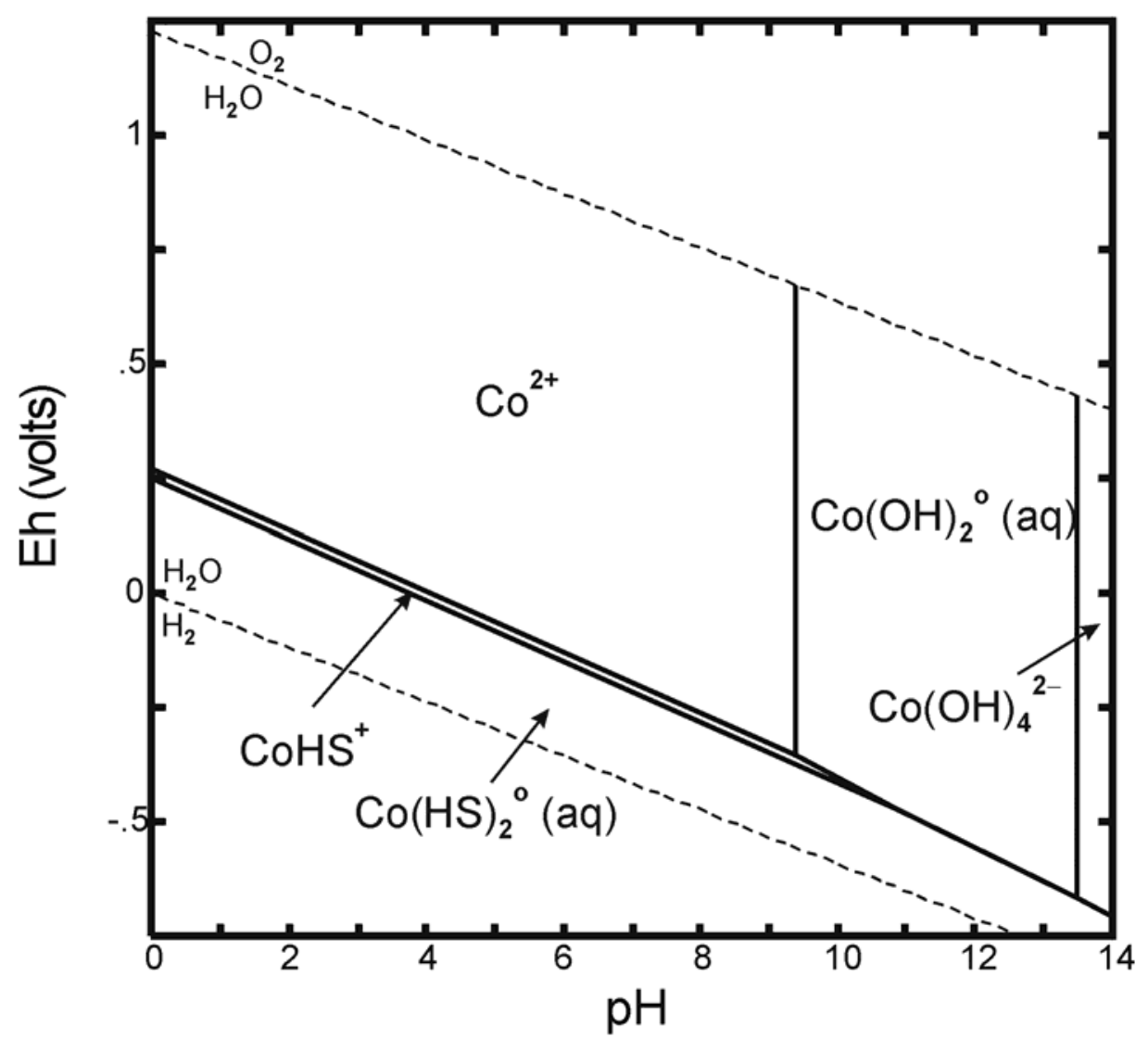

Figure 3.1. Eh-pH Diagram Showing the Dominant Aqueous Complexes of Cobalt [Diagram was calculated at $25^{\circ} \mathrm{C}$ and a concentration of $10^{-14.8} \mathrm{~mol} / \mathrm{L}$ total dissolved cobalt in the presence of dissolved chloride, nitrate, sulfate, and carbonate.] 
As noted earlier, the +3 oxidation state of cobalt can persist in aqueous solutions when stabilized relative to reduction by complexation with certain ligands, such as EDTA and $\mathrm{NH}_{3}$ (Cotton and Wilkinson 1980). Cobalt(III) has a strong affinity for nitrogen donors. The majority of Co(III) complexes contain ammonia, amines, nitro groups, or nitrogen-bonded SCN groups (Cotton and Wilkinson 1980). Very little is known about the hydrolysis of Co(III) due to its reduction by water and slow reaction kinetics (Baes and Mesmer 1976). According to Harmsen and Schulz (1998), Co(III) can also be stabilized relative to reduction by the formation of the cation $\mathrm{Co}^{\mathrm{III}}\left(\mathrm{NO}_{2}\right)_{6}{ }^{3+}$, which is stable in both acidic and alkaline media. Harmsen and Schulz (1998) note that the conditions occurring during the dissolution of nuclear fuels were favorable for conversion of possibly a large fraction of the cobalt to $\mathrm{Co}{ }^{\mathrm{III}}\left(\mathrm{NO}_{2}\right)_{6}{ }^{3+}$.

Cobalt may also form strong complexes with natural and synthetic organic ligands. Complexation of cobalt with humic and fulvic acids has been studied by Glaus et al. (2000), Qian et al. (1998), and others, and is not of major importance relative to the low organic-content sediments at Hanford. Cobalt forms strong complexes with synthetic organic ligands, such as EDTA, that have been used to decontaminate nuclear reactors. ${ }^{\text {a }}$ The formation of such complexes significantly affects the environmental mobility of cobalt by increasing cobalt solubility in aqueous solutions [e.g., Delegard and Barney (1983)], decreasing cobalt adsorption in soils and sediments [e.g., Delegard and Gallagher (1983)], and/or stabilizing the Co(III) valence state in some sediment systems [e.g., Brooks et al. (1996)] (Section 3.4). Species distribution calculations by Brooks et al. (1996) indicated that the $\mathrm{Co}^{\mathrm{II}} \mathrm{EDTA}^{2-}$ will dominate the aqueous speciation of $\mathrm{Co}(\mathrm{II})$ at $\mathrm{pH}$ values greater than 6 . The cobalt complexes $\mathrm{Co}^{\mathrm{II}} \mathrm{EDTA}^{2-}$ and $\mathrm{Co}^{\mathrm{III}} \mathrm{EDTA}^{-}$are anionic, and thus do not readily adsorb to minerals at near neutral and basic $\mathrm{pH}$ conditions. Stability constants for a wide range of $\mathrm{Co}(\mathrm{II})$ and $\mathrm{Co}(\mathrm{III})$ organic complexes, including those with EDTA, HEDTA, and NTA, are tabulated in Smith et al. (1997).

\subsection{Solubility Limits}

At least 73 mineral species that contain cobalt as a necessary structural component are known. ${ }^{b}$ However, no discrete cobalt minerals have been identified in surface sediment and soil systems (Ames and Rai 1978). Cobalt is often found in solid solution with other elements in minerals. Given their similarity in ionic radii, $\mathrm{Co}(\mathrm{II})$ may substitute for $\mathrm{Fe}(\mathrm{II}), \mathrm{Fe}(\mathrm{III}), \mathrm{Mn}(\mathrm{III}), \mathrm{Cu}(\mathrm{II}), \mathrm{Mg}(\mathrm{II}), \mathrm{Cr}(\mathrm{III})$, and $\mathrm{Sn}(\mathrm{IV})$ in the crystal lattices of minerals.

Known cobalt minerals include a diversity of sulfides, arsenides, sulfo-arsenides, arsenates, and selenides. Cobalt is also known to exist as oxide and carbonate minerals, such as sphaerocobaltite $\left(\mathrm{Co}^{\mathrm{II}} \mathrm{CO}_{3}\right)$, nichromite $\left(\mathrm{Ni}, \mathrm{Co}^{\mathrm{II}}, \mathrm{Fe}^{\mathrm{II}}\right)\left(\mathrm{Cr}, \mathrm{Fe}^{\mathrm{III}}, \mathrm{Al}\right)_{2} \mathrm{O}_{4}$, and heterogenite $\left[\mathrm{Co}{ }^{\mathrm{III}} \mathrm{O}(\mathrm{OH})\right.$, in two polytypes $]$. Rose et al. (1979) describe sphaerocobaltite only as a weathering product. No information regarding the geochemical conditions for the formation of nichromite and heterogenite was found during the course of this literature of this review. Hem (1985) notes that the solubility of sphaerocobaltite $\left(\mathrm{CoCO}_{3}\right)$ is lower

a Serne et al. (1996) present the results of a literature review completed on characterization data for radionuclide-chelating agent complexes found in low-level radioactive decontamination waste.

b Statement based on a search of Web-based mineralogical database at http://webmineral.com/chemical.shtml 
than that of siderite $\left(\mathrm{FeCO}_{3}\right)$ and therefore could be an important solubility constraint for dissolved cobalt in some carbonate-containing, basic $\mathrm{pH}$ environmental systems.

Figure 3.2 indicates that at a total concentration of $10^{-14.8} \mathrm{~mol} / \mathrm{L}$ dissolved cobalt, the mineral cattierite $\left(\mathrm{Co}^{\mathrm{II}} \mathrm{S}_{2}\right)$ calculates to be oversaturated under very reducing conditions over a wide $\mathrm{pH}$, but narrow Eh range. Increasing the total concentration of dissolved cobalt to $10^{-12.0} \mathrm{~mol} / \mathrm{L}$ expands the Eh region in which cattierite is thermodynamically oversaturated (Figure 3.3). Figure 3.3 also shows narrow regions of oversaturation at $\mathrm{pH}$ values greater than 9 for $\mathrm{Co}_{3} \mathrm{O}_{4}\left(\mathrm{Co}^{\mathrm{II}} \mathrm{Co}_{2}{ }^{\mathrm{III}} \mathrm{O}_{4}\right)$ and linnaeite $\left(\mathrm{Co}^{\mathrm{II}} \mathrm{Co}_{2}{ }^{\mathrm{III}} \mathrm{S}_{4}\right)$ under oxidizing and reducing conditions, respectively. The predicted stability of linnaeite under reducing conditions is surprising given that Co(III) should not be stable at these very reducing conditions, and may possibly be a result of incorrect thermodynamic data for this cobalt sulfide mineral. It is not known if any analogies can be made between solubility predicted for $\mathrm{Co}^{\mathrm{II}} \mathrm{Co}_{2}{ }^{\mathrm{III}} \mathrm{O}_{4}$ as function of Eh and $\mathrm{pH}$ in Figure 3.3 relative to the solubility of nichromite $\left[\left(\mathrm{Ni}_{,} \mathrm{Co}^{\mathrm{II}}, \mathrm{Fe}^{\mathrm{II}}\right)\left(\mathrm{Cr}, \mathrm{Fe}^{\mathrm{III}}, \mathrm{Al}\right)_{2} \mathrm{O}_{4}\right]$ in geologic systems.

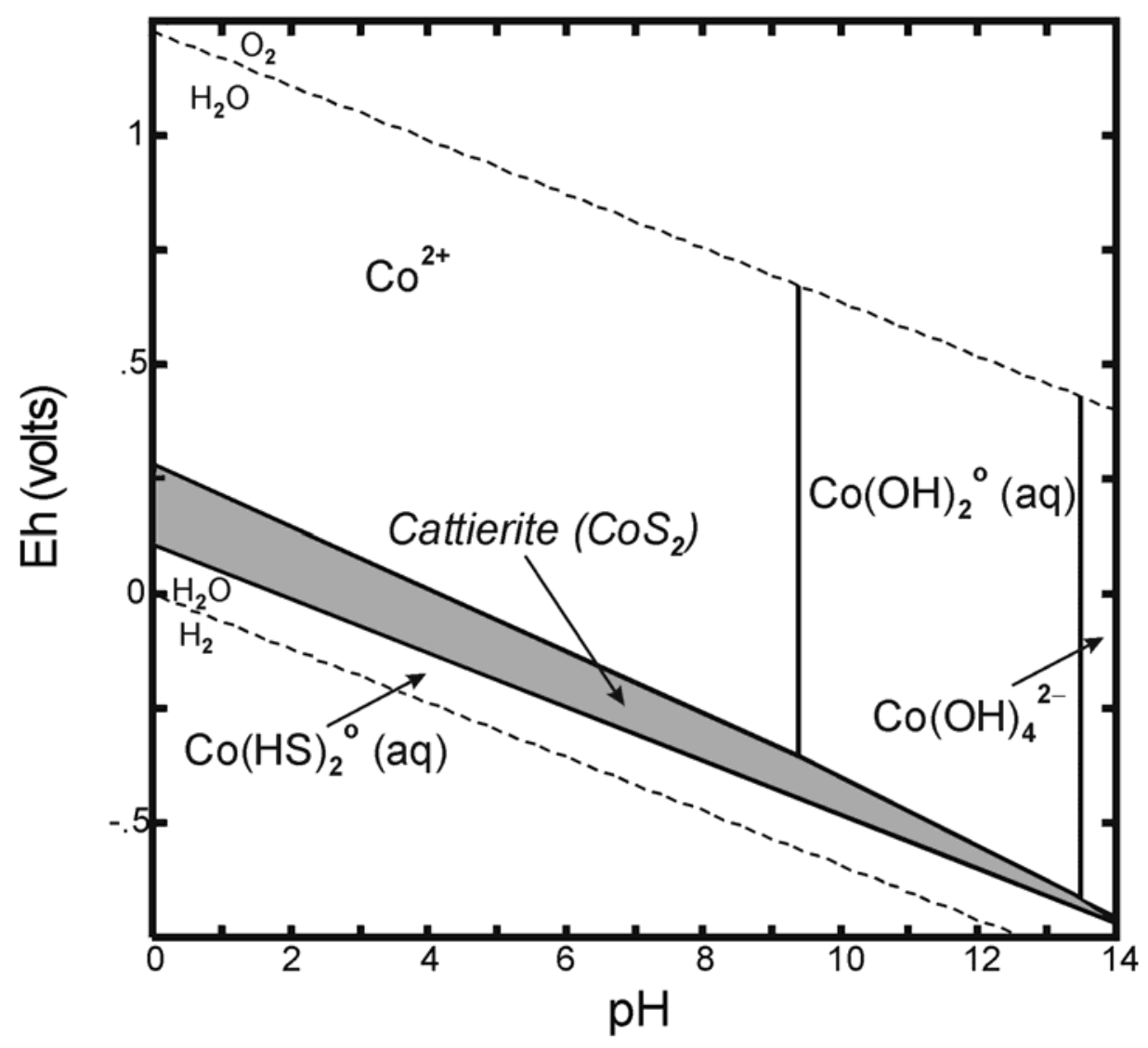

Figure 3.2. Eh-pH Diagram Showing Dominant Aqueous Species of Cobalt and Eh-pH Region (Shaded Area) Where the Solubility of Cattierite Has Been Exceeded [Diagram was calculated at $25^{\circ} \mathrm{C}$ and a concentration of $10^{-14.8} \mathrm{~mol} / \mathrm{L}$ total dissolved cobalt in the presence of dissolved chloride, nitrate, carbonate, and sulfate.] 
PNNL-14126

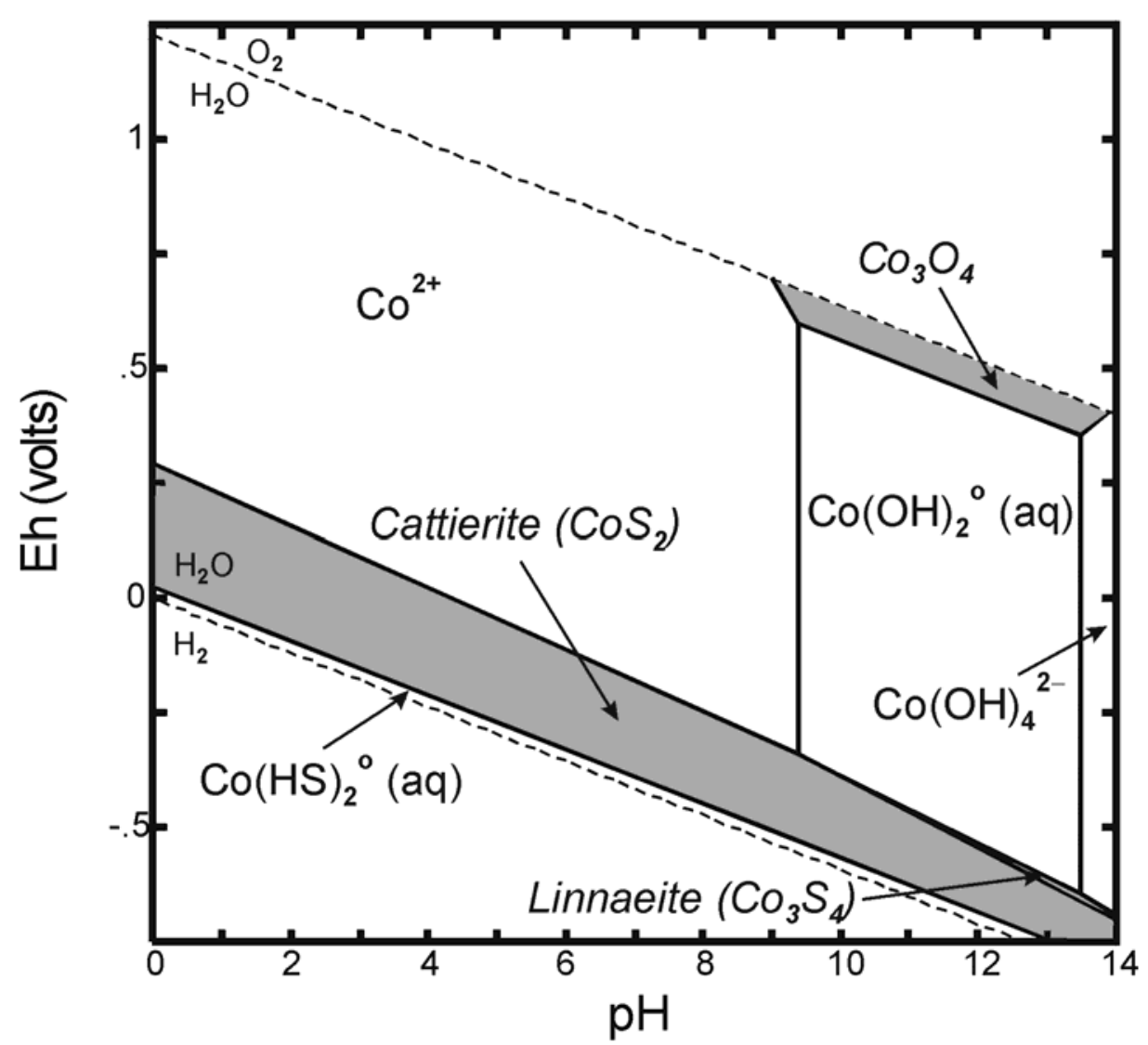

Figure 3.3. Eh-pH Diagram Showing Dominant Aqueous Species of Cobalt and Eh-pH Region (Shaded Area) Where the Solubilities of Cobalt Solids Have Been Exceeded [Diagram was calculated at $25^{\circ} \mathrm{C}$ and a concentration of $10^{-12.0} \mathrm{~mol} / \mathrm{L}$ total dissolved cobalt in the presence of dissolved chloride, nitrate, carbonate, and sulfate.]

As noted above, cobalt is often found in solid solution with other elements in minerals, and may substitute in the crystal lattice for other metals, such as Fe(III), $\mathrm{Fe}(\mathrm{II}), \mathrm{Mn}(\mathrm{III})$, and others due to their similarity in ionic radii. Iron(III) oxides are common mineral components in terrestrial systems. Iron(III) oxides exist in a variety of mineral forms, and are important adsorbents for metals in aqueous systems. They are stable under most oxidizing conditions due to the low solubility of Fe(III) under these redox conditions. The Fe(III) oxides will be solubilized under reducing conditions, which in turn may mobilize any metals coprecipitated in the Fe(III) oxides. The fate of the mobilized metals will be affected by the release of reduced Fe(II) and the nucleation of any Fe(II) solids. Zachara et al. (2001) studied the fate of cobalt that was released under anoxic conditions at near neutral $\mathrm{pH}$ by the bioreduction of synthesized goethite with the composition $\left(\mathrm{Co}_{0.01}{ }^{\mathrm{III}} \mathrm{Fe}_{0.99}{ }^{\mathrm{III}} \mathrm{OOH}\right)$. Zachara et al. (2001) used a dissimilatory iron reducing bacteria (DIRB) Shewanella putrefacians CN32 to reduce the cobalt-substituted goethite and nucleate post-reduction iron solids. Zachara et al. (2001) determined that the Co(III) was mobilized and reduced to $\mathrm{Co}(\mathrm{II})$ as a result of the bacterial iron reduction of cobalt-substituted goethite. The solubilization of $\mathrm{Co}$ (III) was a function of the compositions of the media and buffers, and the fractional 
reduction of the cobalt-substituted goethite. The concentration of dissolved cobalt increased, and thus its mobility in the environment increased, as a result the bioreduction process (Zachara et al. 2001).

\subsection{Adsorption}

The adsorption behavior of cobalt has been studied extensively. Since the mid 1980s, most of these studies have focused on determining a mechanistic understanding of sorption processes for cobalt at the mineral/water interface. The adsorption of cobalt in sediments and soils is largely controlled by the presence of iron and manganese oxide and clay minerals. The adsorption behavior of cobalt is closely linked to its oxidation state, and the environmental availability of natural and man-made organic complexants. Typically, cobalt adsorption studies show that cobalt is moderately to highly adsorbed on minerals in the absence of organic complexants. Recent studies indicate that at high surface loadings, surface-mediated precipitation processes may be responsible for the high adsorption (i.e., large $\mathrm{K}_{\mathrm{d}}$ values) observed for cobalt. Complexation of cobalt by organic ligands, such as EDTA, significantly reduces cobalt adsorption at near neutral and basic $\mathrm{pH}$ values, and has been identified as the cause for enhanced ${ }^{60}$ Co mobility observed at several sites (Killey et al. 1984; Fruchter et al. 1984, 1985; Means et al. 1976, 1978a; Olsen et al. 1986).

\subsubsection{Adsorption in the Absence of Organic Ligands}

The adsorption of cobalt has been studied on a variety of minerals, sediments, soils, and crushed rock materials. Typically, at near neutral and basic $\mathrm{pH}$ values, cobalt in the absence of organic complexants exhibits high adsorption affinity for minerals. The $\mathrm{K}_{\mathrm{d}}$ values commonly reported in the literature range from $10^{3}$ to $10^{5} \mathrm{~mL} / \mathrm{g}$ [e.g., Lowson and Evans (1983), McLaren et al. (1986), Schell et al. (1986), Routson et al. (1987), Serne et al. (1993), Drndarski and Golobočanin (1995), Fujikawa and Fukui (1997), Barrow and Whelan (1998), Carroll et al. (1999), and others]. It should be noted that many investigators, especially those reporting the results of $\mathrm{K}_{\mathrm{d}}$ studies, usually do not specify the oxidation of cobalt in their experiments. Unless otherwise specified, it is safe to assume that their results apply for dissolved Co(II). However, the adsorption behavior of dissolved Co(III) in the absence of organic complexants is expected to be similar to that of $\mathrm{Co}(\mathrm{III})$.

The solution $\mathrm{pH}$ has a significant effect on the adsorption of cobalt. Cobalt in the absence of organic complexants exhibits cation adsorption behavior. As such, the adsorption of cobalt is zero to minimal at acidic conditions, then increases in the $\mathrm{pH}$ range of 4 to 7 with increasing $\mathrm{pH}$, and continues to be high at basic pH conditions (Lowson and Evans 1983; McLaren et al. 1986; Fujikawa and Fukui 1997; Barrow and Whelan 1998; and others). The adsorption behavior of cobalt as a function of $\mathrm{pH}$ is consistent with the known aqueous speciation of Co(II) (Figure 3.1). Fujikawa and Fuki (1997) noted that in highly basic $\mathrm{Na}_{2} \mathrm{CO}_{3}$ solutions, the adsorption of cobalt decreases compared to that at lower $\mathrm{pH}$ values. Fujikawa and Fuki (1997) suggested that this was due to formation of an anionic cobalt hydrolytic aqueous species [e.g., see stability field for $\mathrm{Co}(\mathrm{OH})_{4}{ }^{2-}$ at high $\mathrm{pH}$ in Figure 3.1], which would be poorly adsorbing at high $\mathrm{pH}$ values due to its negative charge.

Although the decrease in cobalt adsorption due to complexation with organic ligands is fairly well known, some inorganic ligands have also been found to inhibit cobalt on sediment. Cantrell and Serne (1993) (see discussion in Section 3.4.2) determined that low concentrations (e.g., $150 \mathrm{ppm}$ ) of 
cyanide $\left(\mathrm{CN}^{-}\right)$can also decrease cobalt adsorption significantly (i.e., $\mathrm{K}_{\mathrm{d}}$ values $<2 \mathrm{~mL} / \mathrm{g}$ ). This is likely due to the formation of anionic $\mathrm{Co}(\mathrm{II})$ complexes, such as $\mathrm{Co}(\mathrm{CN})_{3}{ }^{-}$and $\mathrm{Co}(\mathrm{CN})_{3}{ }^{3-}$ (Smith et al. 1997), which do not readily adsorb on minerals at basic $\mathrm{pH}$ values. Barney (1978) found that that the formation of Co(II) complexes with dissolved nitrite can also decrease the cobalt adsorption. Barney (1978) attributed this decreased adsorption to the formation of poorly-adsorbing neutral or anionic $\mathrm{Co}$ (II)-nitrite complexes for which he cited Cotton and Wilkinson (1962). Cotton and Wilkinson (1962) unfortunately was not available to us during the course of conducting this literature review. However, we found no mention of $\mathrm{Co}(\mathrm{II})$ - or $\mathrm{Co}(\mathrm{III})$-nitrite complexes in a more recent version of this text (Cotton and Wilkinson 1980), or in compilations of thermodynamic constants such as Wagman et al. (1982) or Smith et al. (1997). ${ }^{\text {a }}$ Because cyanide and nitrite are present in the radioactive wastes stored in the underground storage tanks at the Hanford Site, knowledge of their role relative to the mobility of cobalt is important.

Humic substances can also increase the adsorption of certain metals in sediments and soils. Zachara et al. (1994) used experimental measurements and modeling calculations to study the influence of surface-bound humic acid on Co(II) adsorption by the clay-sized fraction of a sediment sample from South Carolina, and by the single mineral sorbents gibbsite $\left[\mathrm{Al}(\mathrm{OH})_{3}\right]$, Al-goethite $\left[\left(\mathrm{Al}_{\sim 0.2} \mathrm{Fe}_{\sim 0.8}\right) \mathrm{OOH}\right]$, and kaolinite $\left[\mathrm{Al}_{2} \mathrm{Si}_{2} \mathrm{O}_{5}(\mathrm{OH})_{4}\right]$. Gibbsite, Al-goethite, and kaolinite were used as model sorbents to help to interpret the adsorption results for the iron and aluminum and iron oxides, and layer silicates present in the sediment sample. Zachara et al. (1994) found that the surface bound humic acid increased cobalt adsorption on all mineral sorbents by 10 to $60 \%$. The largest increase in cobalt adsorption occurred in the $\mathrm{pH}$ range from 4.5 to 6.5 , where the humic acid adsorption was the greatest and cobalt adsorption was weak and dominated by ion exchange (Zachara et al. 1994).

The presence of other dissolved cations, such as the alkali and alkaline earth ions, can decrease cobalt adsorption. Khan et al. (1996) found that the presence of these cations could decrease the adsorption of cobalt on bentonite clay in the order $\mathrm{K}^{+}>\mathrm{Ca}^{2+}>\mathrm{Mg}^{2+}>\mathrm{Na}^{+}$.

The adsorption of cobalt in the absence of organic complexants has been studied on a variety of minerals listed below: ${ }^{\mathrm{b}}$

- Iron oxide and oxyhydroxides (Means et al. 1978b; Ambe et al. 1986; Borggaard 1988; Bibak 1994; Backes et al. 1995; Bibak et al. 1995)

- Manganese oxides (Means et al. 1978b; Crowther et al. 1983; Hem et al. 1985; Dillard and Schenck 1986; Backes et al. 1995; Bibak et al. 1995; Kay et al. 2001)

- $\quad$ Aluminum oxides and hydroxides (Bibak 1994; Katz and Hayes 1995a,b; Towle et al. 1997; Boyle-Wight et al. 2002a,b)

${ }^{\text {a }}$ Harmsen and Schulz (1998) also discuss the formation of $\mathrm{Co}^{\mathrm{III}}\left(\mathrm{NO}_{2}\right)_{6}{ }^{3+}$ in the waste solutions in Hanford's storage. Harmsen and Schulz (1998) state that the anionic complex Co ${ }^{\mathrm{III}}\left(\mathrm{NO}_{2}\right)_{6}{ }^{3+}$ is stable in both acidic and alkaline solutions, but give no supporting reference.

${ }^{b}$ Brown et al. (1990) summarizes the results of published XAS studies of the cobalt adsorption on single mineral phases, such as $\gamma-\mathrm{Al}_{2} \mathrm{O}_{3}$, kaolinite, rutile, quartz, and calcite. The sources of these cobalt adsorption studies are included in the references cited above. 
PNNL-14126

- Clays (O’Day et al. 1994a,b; Khan et al. 1996; McLaren et al. 1998; Chen and Hayes 1999; Thompson et al. 1999)

- Calcite (Xu et al. 1996)

- Quartz $\left(\alpha-\mathrm{SiO}_{2}\right)\left(\mathrm{O}^{\prime}\right.$ Day et al. 1996)

- $\quad$ Rutile $\left(\mathrm{TiO}_{2}\right)$ (O’Day et al. 1996).

The cobalt adsorption on manganese minerals, such as birnessite $\left(\mathrm{MnO}_{2}\right)$ results in the surface-mediated oxidation of $\mathrm{Co}$ (II) to $\mathrm{Co}$ (III) by the reduction of surface Mn(IV) sites (Crowther et al. 1983; Hem et al. 1985; Dillard and Schenck 1986; Kay et al. 2001). X-ray absorption near-edge structure (XANES) measurements by Kay et al. (2001) indicate that most of the Co(II) is oxidized to Co(III) and that the $\mathrm{Co}$ (III) appears to be structurally incorporated (i.e., absorbed or coprecipitated) into the manganese minerals. In adsorption measurements conducted with birnessite, Crowther et al. (1983) determined that the oxidation of $\mathrm{Co}$ (II) to $\mathrm{Co}$ (III) occurred at $\mathrm{pH}$ values of 4,6 , and 7 . However, in experiments conducted at $\mathrm{pH} 8$ and $10, \mathrm{Co}(\mathrm{II})$ adsorption resulted in the precipitation of a $\mathrm{Co}$ (I $(\mathrm{OH})_{2}$-like phase or cluster on the birnessite surface (Crowther et al. 1983). The $\mathrm{Co}^{\mathrm{II}}(\mathrm{OH})_{2}$-like phase is similar but not identical structurally to crystalline $\mathrm{Co}^{\mathrm{II}}(\mathrm{OH})_{2}$. The formation of such surface structures could explain the large $\mathrm{K}_{\mathrm{d}}$ values $\left(10^{3}-10^{5} \mathrm{ml} / \mathrm{g}\right)$ often reported in the literature for the adsorption of cobalt in the absence of strong inorganic or organic complexing ligands.

The $\mathrm{Co}^{\mathrm{II}}(\mathrm{OH})_{2}$-like, surface-precipitate structures have also been identified from adsorption studies of high surface coverages of Co(II) on quartz (O’Day et al. 1996), kaolinite (O'Day et al. 1994a,b; Thompson et al. 1999), $\mathrm{Al}_{2} \mathrm{O}_{3}$ (Towle et al. 1997), and clays (Chen and Hayes 1999). O'Day et al. (1996) identified a $\mathrm{Co}^{\mathrm{II}}(\mathrm{OH})_{2}$-like, surface-precipitate structure from XAS and EXAFS analysis of Co(II) adsorbed on quartz. For the adsorption of $\mathrm{Co}(\mathrm{II})$ on $\mathrm{Al}_{2} \mathrm{O}_{3}$, Towle et al. (1997) described the surface precipitate as double hydroxide phase containing $\mathrm{Al}^{3+}$ ions derived from the $\mathrm{Al}_{2} \mathrm{O}_{3}$ substrate. Results of studies by Thompson et al. (1999) indicate that in the case of cobalt adsorption on kaolinite, the surface-precipitate may have a hydrotalcite-like structure containing aluminum ions resulting from the dissolution of kaolinite. Thompson et al. (1999) indicated that the hydrotalcite-like precipitate has an approximate stoichiometry of $\mathrm{Co}_{6} \mathrm{Al}_{2}(\mathrm{OH})_{16}\left(\mathrm{~A}^{\mathrm{n}-}\right)_{2 / \mathrm{n}}$ where $\mathrm{A}$ is nitrate or silica. Chen and Hayes (1999) found that under high $\mathrm{pH}$ conditions, increasing the concentrations of dissolved sodium did not displace the cobalt coprecipitated in these $\mathrm{Co}$ II $(\mathrm{OH})_{2}$-like structures.

Xu et al. (1996) investigated the uptake of dissolved cobalt by calcite surfaces. Their X-ray photoelectron spectroscopy (XPS) measurements indicated that the sorbed $\mathrm{Co}$ (II) species probably exists as coprecipitated $(\mathrm{Ca}, \mathrm{Co})$-carbonate solid solution at the calcite/water interface.

\subsubsection{Adsorption in the Presence of Organic Ligands}

The presence of certain natural and synthetic organic ligands are known to reduce the adsorption of cobalt on sediments, soils, minerals, and other geologic materials especially at basic conditions. For example, cobalt adsorption on geologic materials has been shown to decrease by the presence citric acid (Khan et al. 1996), oxalic acid (Khan et al. 1996; did not observe a large decrease in cobalt adsorption), 
EDTA (Wilding and Rhodes 1963; Cantrell and Serne 1993; Girvin et al. 1993; Jardine et al. 1993; Szecsody et al. 1994, 1998; Jardine and Taylor 1995; Zachara et al. 1995a,b; Khan et al. 1996; Fendorf et al. 1999), hydroxyethylethylenediaminetriacetate acid (HEDTA) (Delegard and Barney 1983), ${ }^{a}$ diethylenetriaminepentaacetic acid (DTPA) (Khan et al. 1996), cyclohexanediaminetetraacetic acid (CDTA) (Khan et al. 1996), and nitrilotriacetic acid (NTA) (Girvin et al. 1996). The reader should consider this list of complexants (and supporting references) as only examples of some of the organic ligands that affect the fate of cobalt in the environment. This decrease in cobalt adsorption is typically caused by the formation of anionic cobalt complexes at near neutral and basic $\mathrm{pH}$ conditions, which do not readily adsorb on mineral surfaces at basic $\mathrm{pH}$ values. As noted in Section 3.4.1, cobalt in the absence of organic complexants normally exhibits cationic adsorption behavior, and the adsorption of cobalt is zero to minimal at acidic conditions and then increases with increasing $\mathrm{pH}$. The formation of anionic cobalt complexes (inorganic or organic) reverses this trend in adsorption at basic $\mathrm{pH}$ conditions.

Since the early 1990s, research has focused primarily on understanding the mechanisms controlling the aqueous speciation and complexation, oxidation/reduction, and sorption of cobalt in the presence of EDTA at the solution/mineral interface (Girvin et al. 1993; Jardine et al. 1993; Szecsody et al. 1994, 1998; Jardine and Taylor 1995; Zachara et al. 1995a,b, 2000; Brooks et al. 1996; Gorby et al. 1998; Fendorf et al. 1999). This research topic was prompted by the enhanced migration of ${ }^{60} \mathrm{Co}$ reported at some DOE sites, such as the Hanford Site (Fruchter et al. 1984, 1985) and Oak Ridge National Laboratory (Means et al. 1976, 1978a; Olsen et al. 1986). As stated previously, the enhanced migration of ${ }^{60} \mathrm{Co}$ was attributed to the formation of Co-EDTA complexes resulting from the co-disposal of cobalt and EDTA at these sites. ${ }^{\text {b }}$ Cobalt(II) is initially complexed to form the anionic complex Co ${ }^{\text {II }}$ EDT $^{2-}$. This complex however is then dissociated via a complex series of reactions that result in the oxidation of $\mathrm{Co}(\mathrm{II})$ to $\mathrm{Co}(\mathrm{III})$ and formation of the more stable and mobile complex $\mathrm{Co}^{\mathrm{III}} \mathrm{EDTA}^{-}\left[\log \mathrm{K}\left(\mathrm{Co}^{\mathrm{III}} \mathrm{EDTA}^{-}\right)\right.$ $=41.4$ versus $\log \mathrm{K}\left(\mathrm{Co}^{\mathrm{II}} \mathrm{EDTA}^{2-}\right)=16.45$ (Zachara et al. 1995a,b, 2000; Brooks et al. 1996; Szecsody et al. 1998). The reaction process initially involves the adsorption of Co ${ }^{\text {II }} \mathrm{EDTA}^{2-}$ to surface sites on the iron and aluminum oxides in the sediments, which in turn leads to the dissolution of these oxides. The dissociation of $\mathrm{Co}^{\mathrm{II}} \mathrm{EDTA}^{2-}$ is advanced by the solubilized Fe(III) and $\mathrm{Al}(\mathrm{III})$. The dissolution-exchange reaction generates a suite of adsorbates $\mathrm{Co}^{2+}, \mathrm{Co}^{\mathrm{II}} \mathrm{EDTA}^{2-}$, FeEDTA, and AlEDTA ${ }^{-}$that compete for the EDTA and surface adsorption sites. The sorbed Co(II) is then oxidized to the extremely stable but weakly

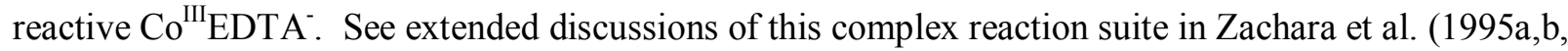
2000) and Brooks et al. (1996). This reaction suite seems to be common to sediments and soils of different compositions and origin (Zachara et al. 1995a). Brooks et al. (1996) found that the oxidation of $\mathrm{Co}^{\mathrm{II}} \mathrm{EDTA}^{2-}$ was decreased under anoxic conditions, but not eliminated. In the case of $\mathrm{Mn}(\mathrm{IV})$ minerals,

a The studies of Delegard and Barney (1983) indicated that the presence of EDTA increased (not decreased) cobalt adsorption. Delegard and Barney (1983) were perplexed by these EDTA results because they were contrary to their own results for HEDTA and those published by numerous others for EDTA. Delegard and Barney (1983) could not rationalize the EDTA results, and hoped to conduct additional experiments to explain the Co-EDTA results.

${ }^{\mathrm{b}}$ In batch ${ }^{60} \mathrm{Co}$ adsorption experiments using EDTA and cyanide with sediment collected near the 200-BP-1 operable unit cribs at the Hanford Site, Cantrell and Serne (1993) (see discussion in Section 3.4.3) concluded that cyanide was more effective (i.e., lower concentrations were required) than EDTA in depressing ${ }^{60} \mathrm{Co}$ adsorption. 
such as pyrolusite $\left(\beta-\mathrm{Mn}^{\mathrm{IV}} \mathrm{O}_{2}\right)$, the adsorption and subsequent oxidation of $\mathrm{Co}^{\mathrm{II}} \mathrm{EDTA}^{2-}$ to produce $\mathrm{Co}^{\mathrm{III}} \mathrm{EDTA}^{-}$results in the reduction of $\mathrm{Mn}(\mathrm{IV})$ to $\mathrm{Mn}(\mathrm{III})$ and the formation of a layer of $\alpha-\mathrm{Mn}_{2}{ }^{\mathrm{III}} \mathrm{O}_{2}$ on the pyrolusite, which eventually limits the production of $\mathrm{Co}^{\mathrm{III}} \mathrm{EDTA}^{-}$(Fendorf et al. 1999).

Bacterial reduction processes can destabilize the $\mathrm{Co}^{\mathrm{III}} \mathrm{EDTA}^{-}$complexes resulting in an increase of cobalt adsorption in sediments containing iron and manganese oxides. The dissimilatory iron reducing bacterium Shewanella alga strain BrY has been shown to enzymatically reduce $\mathrm{Co}^{\mathrm{III}} \mathrm{EDTA}^{-}$to the less stable Co ${ }^{\text {II EDTA }}{ }^{2-}$ (Gorby et al. 1998; Zachara et al. 2001). During this reduction process, the concentration of dissolved $\mathrm{Fe}(\mathrm{II})$ increases, which in turn causes the dissociation of $\mathrm{Co}^{\mathrm{II}} \mathrm{EDTA}^{2-}$ to a mixture of $\mathrm{Co}^{2+}, \mathrm{Co}^{\mathrm{II}} \mathrm{EDTA}^{2-}$, and the more stable $\mathrm{Fe}^{\mathrm{II}} \mathrm{EDTA}^{2-}$ (Zachara et al. 2001). The uncomplexed $\mathrm{Co}^{2+}$ is then available to adsorb on mineral surfaces at near neutral and basic $\mathrm{pH}$ conditions, and thus decrease the dissolved concentration and mobility of cobalt in sediments under these conditions. In sulfate containing systems, the sulfate reducing bacterium Desulfovibrio vulgaris reduces $\mathrm{Co}^{\mathrm{III}} \mathrm{EDTA}^{-}$to $\mathrm{Co}^{\mathrm{II}} \mathrm{EDTA}^{2-}$ as a result of sulfide production (Blessing et al. 2001). The sulfate-reduction reaction process involves the formation of polysulfide and subsequent precipitation of $\mathrm{CoS}$ solid. (Blessing et al. 2001).

\subsubsection{Hanford Sediment Cobalt Adsorption Studies}

Several studies of the adsorption of Co(II) on sediments from the Hanford Site have been completed. Studies include those by Barney (1978), Gee and Campbell (1980), Delegard and Barney (1983), Routson et al. (1981, 1987), Cantrell and Serne (1993), Serne et al. (1993), and Zachara et al. (1995a,b). Based on a compilation of $\mathrm{K}_{\mathrm{d}}$ values reported in $\mathrm{Co}(\mathrm{II})$ adsorption studies using Hanford Site sediments by Gee and Campbell (1980), Delegard and Barney (1983), Cantrell and Serne (1993), and Serne et al. (1993), Cantrell et al. (2002) concluded that cobalt is highly immobile (i.e., $\mathrm{K}_{\mathrm{d}}>10^{3} \mathrm{~mL} / \mathrm{g}$ ) for natural groundwater conditions at the Hanford Site in the absence of organic chelating agents, such as EDTA.

Gee and Campbell (1980) used batch equilibration methods to measure $\mathrm{K}_{\mathrm{d}}$ values for ${ }^{60} \mathrm{Co}$ and ${ }^{60} \mathrm{Co}$ complexed with EDTA on a sandy sediment from the Hanford Site. The sediment sample consisted of a surface sand common to the Hanford Site, which had a low cation exchange capacity and low percentages of silt- and clay-size particles. The sorption experiments were conducted using six synthetic groundwater and two nitrate salt solutions. The synthetic groundwater solutions differed in their concentrations of dissolved sodium, potassium, calcium, magnesium, carbonate/bicarbonate, sulfate, chloride and nitrate. The low nitrate salt solution consisted of $0.15 \mathrm{M} \mathrm{NaNO}_{3}, 0.01 \mathrm{M} \mathrm{KNO}_{3}$, and $0.002 \mathrm{M} \mathrm{Ca}\left(\mathrm{NO}_{3}\right)_{2}$. The high nitrate salt solution was composed of $0.15 \mathrm{M} \mathrm{NaNO}_{3}, 0.15 \mathrm{KNO}_{3}$, and $0.01 \mathrm{M} \mathrm{Ca}\left(\mathrm{NO}_{3}\right)_{2}$. The $\mathrm{K}_{\mathrm{d}}$ values determined by Gee and Campbell (1980) for ${ }^{60} \mathrm{Co}$ and ${ }^{60} \mathrm{Co}$ complexed with EDTA $\left({ }^{60} \mathrm{Co}\right.$-EDTA) are listed in Table 3.1. The large $\mathrm{K}_{\mathrm{d}}$ values $(2,735$ to $11,070 \mathrm{~mL} / \mathrm{g})$ measured for uncomplexed ${ }^{60} \mathrm{Co}$ in the groundwater solutions indicates that ${ }^{60} \mathrm{Co}$ in the absence of EDTA is highly sorbed on the sandy sediment and relatively immobile under these conditions. The $\mathrm{K}_{d}$ values for ${ }^{60} \mathrm{Co}$ complexed with EDTA, on the other hand, are essentially three orders of magnitude lower that those for uncomplexed ${ }^{60} \mathrm{Co}$. These low $\mathrm{K}_{\mathrm{d}}$ values $(0.1$ to $1.4 \mathrm{~mL} / \mathrm{g})$ indicate that ${ }^{60} \mathrm{Co}$ is poorly sorbed and highly mobile when complexed with EDTA. 
PNNL-14126

Table 3.1. $\mathrm{K}_{\mathrm{d}}$ values determined for ${ }^{60} \mathrm{Co}$ and ${ }^{60} \mathrm{Co}$ Complexed EDTA by Gee and Campbell (1980)

\begin{tabular}{|c|c|c|}
\hline \multirow[b]{2}{*}{ Solution } & \multicolumn{2}{|c|}{$K_{d}$ and Standard Deviation $(\mathrm{mL} / \mathrm{g})$} \\
\hline & ${ }^{60} \mathrm{Co}$ & ${ }^{60} \mathrm{Co}-\mathrm{EDTA}$ \\
\hline 1 & $4,570 \pm 650$ & $1.0 \pm$ \\
\hline 2 & $2,750 \pm 200$ & $1.2 \pm \quad 1$ \\
\hline 3 & $3,670 \pm 160$ & $1.4 \pm \quad 0.3$ \\
\hline 4 & $11,070 \pm 6,480$ & nd \\
\hline 5 & $2,735 \pm 490$ & nd \\
\hline 6 & $4,090 \pm 620$ & nd \\
\hline Low Nitrate Salt & nd & $0.1 \pm \quad 1$ \\
\hline High Nitrate Salt & nd & $0.9 \pm$ \\
\hline \multicolumn{3}{|c|}{ "nd" refers to values not determined by investigators. } \\
\hline
\end{tabular}

Routson et al. (1987) studied the adsorption of ${ }^{60} \mathrm{Co}$ on sediments taken from crib monitoring wells in the 200 East and 200 West Separations Areas at the Hanford Site. Batch adsorption measurements were completed using 21 sediment types identified from wells 299-E13-8, 299-E33-22, and 299-E17-4 from the 200 East Area, and wells 299-W22-25 and 299-W10-9 from the 200 West Area. The $\mathrm{K}_{\mathrm{d}}$ values were determined using the different sediment types and solutions composed of $0.002,0.02,0.05,0.10$ and

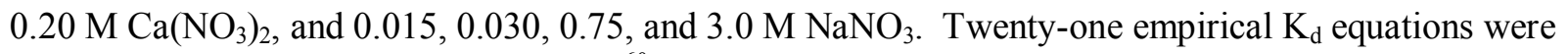
developed from the adsorption results of ${ }^{60} \mathrm{Co}$ on the 21 sediment types. The $\mathrm{K}_{\mathrm{d}}$ values measured by Routson et al. (1987) ranged from 1,600 to $14,000 \mathrm{~mL} / \mathrm{g}$, and have an average value of 4,400 mL/g. For the solution systems studied, Routson et al. (1987) determined that the adsorption of ${ }^{60} \mathrm{Co}$ was controlled only by the concentration of dissolved calcium. These results suggested to Routson et al. (1987) that cobalt adsorption might be partially controlled by ion exchange processes. Based on the large $\mathrm{K}_{\mathrm{d}}$ values measured for ${ }^{60} \mathrm{Co}$ relative to those for strontium, Routson et al. (1987) also proposed that cobalt adsorption might be partially controlled by a precipitation-like reaction. Routson et al. (1987) appears to contain results and $\mathrm{K}_{\mathrm{d}}$ values for a subset of batch adsorption experiments completed with the same sediment samples and solutions by Routson et al. (1981). The general conclusions and ${ }^{60} \mathrm{Co} \mathrm{K}_{\mathrm{d}}$ values given in Routson et al. (1987) for the 21 sediment types and $\mathrm{Ca}\left(\mathrm{NO}_{3}\right)_{2}$ and $\mathrm{NaNO}_{3}$ solutions do not differ from those in Routson et al. (1981). Routson et al. (1981) however, does include adsorption results for additional $\mathrm{Ca}\left(\mathrm{NO}_{3}\right)_{2}$ and $\mathrm{NaNO}_{3}$ solution compositions as well as for a matrix of $\mathrm{KNO}_{3}$ solutions.

Cantrell and Serne (1993) conducted batch adsorption experiments to measure the adsorption of ${ }^{60} \mathrm{Co}$ on sediment collected near the 200-BP-1 operable unit cribs at the Hanford Site. The sediment samples were taken in the area of the cribs at depths of $159.6 \mathrm{ft}$ (sample ID 699-52-57) and $210.0 \mathrm{ft}$ (sample ID 699-55-55). Adsorption experiments were completed using groundwater samples from wells 699-50-53 and 699-S3-25. The $\mathrm{K}_{\mathrm{d}}$ values measured in the initial set of experiments using groundwater from well 699-50-53 are given at the top of Table 3.2, and are significantly lower than those typically reported in the literature for cobalt. Cantrell and Serne (1993) hypothesized that the complexation of ${ }^{60} \mathrm{Co}$ 
by ligand(s) dissolved in the groundwater sample from well 699-50-53 caused the low $\mathrm{K}_{\mathrm{d}}$ values. To test this hypothesis, Cantrell and Serne (1993) conducted additional adsorption experiments with sediment sample 699-55-55 using groundwater from well 699-S3-25 instead of that from well 699-50-53. The average $\mathrm{K}_{\mathrm{d}}$ measured by Cantrell and Serne (1993) for ${ }^{60} \mathrm{Co}$ in well 699-S3-25 groundwater was $2,560 \mathrm{~mL} / \mathrm{g}$ (Table 3.2), which is more typical for the range of $\mathrm{K}_{\mathrm{d}}$ values reported for cobalt. Because dissolved cyanide and EDTA were known to be present in contaminated groundwater at certain locations at the Hanford Site, Cantrell and Serne (1993) proposed that ${ }^{60} \mathrm{Co}$ may have formed complexes with these ligands that did not readily adsorb to sediment and resulted in low $\mathrm{K}_{\mathrm{d}}$ values. To test the role of dissolved cyanide and EDTA, Cantrell and Serne (1993) completed a series of $K_{d}$ measurements using sediment 699-52-57 and groundwater from well 699-S3-25 spiked with various concentrations of cyanide and EDTA. The ${ }^{60} \mathrm{Co} \mathrm{K}_{\mathrm{d}}$ values (bottom of Table 3.2) measured in these cyanide- and EDTA-containing solutions confirm that cyanide concentrations typical of those measured previously in groundwater samples from well 699-50-53 and high concentrations of EDTA both significantly reduce the adsorption of ${ }^{60} \mathrm{Co}$ onto sediment from the 200-BP-1 area.

Table 3.2. $\mathrm{K}_{\mathrm{d}}$ Values Determined for ${ }^{60} \mathrm{Co}$ by Cantrell and Serne (1993)

\begin{tabular}{|l|c|c|c|c|c||}
\hline \multicolumn{1}{|c|}{ Groundwater Solution } & Sediment Sample & \multicolumn{3}{c|}{$K_{\mathbf{d}}$ Values (mL/g) } & $\begin{array}{c}\text { Average } \mathbf{K}_{\mathbf{d}} \\
\text { (mL/g) }\end{array}$ \\
\hline \hline $699-50-53$ & $699-52-57$ & 0.05 & 0.27 & 0.23 & 0.2 \\
\hline $699-50-53$ & $699-55-55$ & 0.07 & 0.17 & 0.13 & 0.1 \\
\hline & & & & & \\
\hline 6-S3-25 & $699-55-55$ & $\mathrm{nr}$ & $\mathrm{nr}$ & $\mathrm{nr}$ & 2,560 \\
\hline & & & & & \\
\hline 6-S3-25 with 150 ppb CN & $699-52-57$ & 2.1 & 2.0 & 1.7 & 1.9 \\
\hline 6-S3-25 with 2,000 ppb CN & $699-52-57$ & 0.0 & 0.1 & 0.0 & 0.0 \\
\hline & & & & & \\
\hline 6-S3-25 with 25 ppb EDTA & $699-52-57$ & 1,000 & 1,230 & 982 & 1,070 \\
\hline 6-S3-25 with 200 ppb EDTA & $699-52-57$ & 79 & 71 & 65 & 71 \\
\hline 6-S3-25 with 2,000 ppb EDTA & $699-52-57$ & 2.6 & 3.4 & 3.8 & 3.3 \\
\hline "nr" indicates individual K values were not reported in Cantrell and Serne (1993) & \\
\hline
\end{tabular}

Serne et al. (1993) used the batch adsorption technique to measure $\mathrm{K}_{\mathrm{d}}$ values for ${ }^{60} \mathrm{Co}$ in groundwater contacting the $<2-\mathrm{mm}$ size fraction of a sample of loamy sand from Trench- 8 at the Hanford Site. The measurements were conducted using uncontaminated groundwater with an initial $\mathrm{pH}$ of 8.14 from the Hanford Site. The particle size distribution for the in-situ Trench- 8 sediment contained $9.7 \%$ gravel, $78.6 \%$ sand, $6.3 \%$ silt, and $5.4 \%$ clay. The $<2-\mathrm{mm}$ size fraction of this sediment consisted of $87 \%$ sand, $7 \%$ silt, and $6 \%$ clay. The $\mathrm{K}_{\mathrm{d}}$ values measured ${ }^{60} \mathrm{Co}$ at 5 and 44 days were $12,500 \pm 600$ and $11,600 \pm 600 \mathrm{~mL} / \mathrm{g}$, respectively. The $\mathrm{pH}$ of the Trench- 8 sediment-groundwater slurry was 8.22 at 44 days. 
Zachara et al. (1995a,b) studied the oxidation, adsorption, and dissociation of Co-EDTA complexes on subsurface materials. Some of the sorbents used in their Co-EDTA sorption experiments included unconsolidated Pliocene fluvial sediment (quartz sand) from the Upper Ringold Formation sampled from the White Bluffs area across the Columbia River from the Hanford Site. The results of the studies by Zachara et al. (1995a,b) have already been discussed in Section 3.4.2.

\subsection{References}

Ambe F, S Ambe, T Okada, and H Sekizawa. 1986. "In Situ Mössbauer Studies of Metal-OxideAqueous Solution Interfaces with Adsorbed Cobalt-57 and Antimony-118 Ions." In Geochemical Processes at Mineral Surfaces, JA Davis and KF Hayes (eds.), Chapter 19, pp. 403-424, ACS Symposium Series 323, American Chemical Society, Washington, D.C.

Ames LL and D Rai. 1978. Radionuclide Interactions with Soil and Rock media. Volume 1: Processes Influencing Radionuclide Mobility and Retention, Element Chemistry and Geochemistry, and Conclusions and Evaluations. EPA 520/6-78-007-a, U.S. Environmental Protection Agency, Las Vegas, Nevada.

Backes CA, RG McLaren, AW Rate, and RS Swift. 1995. "Kinetics of Cadmium and Cobalt Desorption from Iron and Manganese Oxides.” Soil Science Society of America Journal, 59:778-785.

Baes CF, Jr and RF Mesmer. 1976. The Hydrolysis of Cations. John Wiley and Sons, New York, New York.

Barney GS. 1978. Variables Affecting Sorption and Transport of Radionuclides in Hanford Subsoils. RHO-SA-87, Rockwell Hanford Operations, Richland, Washington.

Barrow NJ and BR Whelan. 1998. "Comparing the Effects of $\mathrm{pH}$ on the Sorption of Metals by Soil and By Goethite, and On Uptake by Plants.” European Journal of Soil Science, 49:683-692.

Bibak A. 1994. "Cobalt, Copper, and Manganese Adsorption by Aluminum and Iron-Oxides and Humic-Acid." Communications in Soil Science and Plant Analysis, 25:3229-3239.

Bibak A, J Gerth, and OK Borggaard. 1995. "Retention of Cobalt by an Oxisol in Relation to the Content of Iron and Manganese Oxides." Communications in Soil Science and Plant Analysis, 26:785-798.

Blessing TC, BW Wielinga, MJ Morra, and S Fendorf. 2001. "Co "EDTA“ Reduction by Desulfovibria vulgaris and Propagation of Reactions Involving Dissolved Sulfide and Polysulfides." Environmental Science and Technology, 35:1599-1603.

Borggaard OK. 1988. "Adsorption of Cobalt by Soil Iron-Oxides at Low Solution Concentrations." Communications in Soil Science and Plant Analysis, 19:447-459.

Boyle-Wight EJ, LE Katz, and KF Hayes. 2002a. "Macroscopic Studies of the Effects of Selenate and Selenite on Cobalt Sorption to $\gamma-\mathrm{Al}_{2} \mathrm{O}_{3}$." Environmental Science and Technology, 36:1212-1218. 
Boyle-Wight EJ, LE Katz, and KF Hayes. 2002b. "Spectroscopic Studies of the Effects of Selenate and Selenite on Cobalt Sorption to $\gamma-\mathrm{Al}_{2} \mathrm{O}_{3}$." Environmental Science and Technology, 36:1219-1225.

Brooks SC, DL Taylor, and PM Jardine. 1996. "Reactive Transport of EDTA-Complexes Cobalt in the Presence of Ferrihydrite.” Geochimica et Cosmochimica Acta, 60:1899-1908.

Brown GE, Jr. 1990. "Spectroscopic Studies of Chemisorption Reaction Mechanisms at Oxide-Water Interfaces." In Mineral-Water Interface Geochemistry, MF Hochella, Jr and AF White (eds.), pp. 309-363, Reviews in Mineralogy, Volume 23, Mineralogical Society of America, Washington, D.C.

Cantrell KJ and RJ Serne. 1993. Appendix F. Adsorption of Co-60, Sr-90, Tc-99, Cs-137, Pu and Cyanide on 200-BP-1 Sediment. In Phase I Remedial Investigation Report for 200-BP-1 Operable Unit, DOE/RL-92-70, Volume 2, Revision 0, U.S. Department of Energy, Richland, Washington.

Cantrell KJ, RJ Serne, and GV Last. 2002. Hanford Contaminant Distribution Coefficient Database and Users Guide. PNNL-13895, Pacific Northwest National Laboratory, Richland, Washington.

Carroll J, F Boisson, J-L Teyssie, SE King, M Krosshavn, ML Carroll, SW Fowler, PP Povinec, and MS Baxter. 1999. "Distribution Coefficients $\left(\mathrm{K}_{\mathrm{d}}\right.$ 's) for Use in Risk Assessment Models of the Kara Sea." Applied Radiation and Isotopes, 51:121-129.

Chen C-C and KF Hayes. 1999. "X-ray Absorption Spectroscopy Investigation of Aqueous Co(II) and Sr(II) Sorption at Clay-Water Interfaces.” Geochimica et Cosmochimica Acta, 63:3205-3215.

Cotton FA and G Wilkinson. 1962. Advanced Inorganic Chemistry. A Comprehensive Text. John Wiley and Sons, New York, New York.

Cotton FA and G Wilkinson. 1980. Advanced Inorganic Chemistry. A Comprehensive Text. Fourth Edition, John Wiley and Sons, New York, New York.

Crowther DL, JG Dillard, and JW Murray. 1983. "The Mechanism of Co(II) Oxidation on Synthetic Birnessite." Geochimica et Cosmochimica Acta, 47:1399-1403.

Delegard CH and GS Barney. 1983. Effects of Hanford High-Level Waste Components on the Sorption of Cobalt, Strontium, Neptunium, Plutonium, and Americium on Hanford Sediments. RHO-RE-ST-1 P, Rockwell Hanford Operations, Richland, Washington.

Delegard CH and SA Gallagher. 1983. Effects of Hanford High-Level Waste Components on the Solubility of Cobalt, Strontium, Neptunium, Plutonium, and Americium. RHO-RE-ST-3 P, Rockwell Hanford Operations, Richland, Washington.

Dillard JG and CV Schenck. 1986. "Interaction of Co(II) and Co(III) Complexes on Synthetic Birnessite: Surface Characterization." In Geochemical Processes at Mineral Surfaces, JA Davis and KF Hayes (eds.), Chapter 24, pp. 503-522, ACS Symposium Series 323, American Chemical Society, Washington, D.C. 
PNNL-14126

Drndarski N and D Golobočanin. 1995. "Radionuclide Partitioning Coefficients in the Sava River Ecosystem.” Journal of Radioanalytical and Nuclear Chemistry, Letters, 199:21-26.

Fendorf S, PM Jardine, RR Patterson, DL Taylor, and SC Brooks. 1999. "Pyrolusite Surface Transformations Measured in Real-Time during the Reactive Transport of Co(II)EDTA 2-." Geochimica et Cosmochimica Acta, 63:3049-3057.

Fruchter JS, CE Cowan, DE Robertson, DC Girvin, EA Jenne, AP Toste, and KH Abel. 1984. Radionuclide Migration in Groundwater. Annual Report for FY 1983. NUREG/CR-3712 (PNL-5040), U.S. Nuclear Regulatory Commission, Washington, D.C.

Fruchter JS, CE Cowan, DE Robertson, DC Girvin, EA Jenne, AP Toste, and KH Abel. 1985. Radionuclide Migration in Groundwater. Final Report. NUREG/CR-4030 (PNL-5299), U.S. Nuclear Regulatory Commission, Washington, D.C.

Fujikawa Y and M Fukui. 1997. "Radionuclide Sorption to Rocks and Minerals: Effects of $\mathrm{pH}$ and Inorganic Anions. Part 1. Sorption of Cesium, Cobalt, Strontium, and Manganese." Radiochimica Acta, 76:153-162.

Gee GW and AC Campbell. 1980. Monitoring and Physical Characterization of Unsaturated Zone Transport - Laboratory Analysis. PNL-3304, Pacific Northwest Laboratory, Richland, Washington.

Girvin DC, PL Gassman, and H Bolton, Jr. 1993. Adsorption of Aqueous Cobalt Ethylenediaminetetraacetate by $\delta-\mathrm{Al}_{2} \mathrm{O}_{3}$." Soil Science Society of America Journal, 57:47-57.

Girvin DC, PL Gassman, and H Bolton, Jr. 1996. "Adsorption of Nitrilotriacetate (NTA), Co, and CoNTA by Gibbsite." Clays and Clay Minerals, 44:757-768.

Glasby GP and HD Schulz. 1999. " $\mathrm{E}_{\mathrm{H}}, \mathrm{pH}$ Diagrams for Mn, Fe, Co, Ni, Cu and As Under Seawater Conditions: Application of Two New Types of $\mathrm{E}_{\mathrm{H}}, \mathrm{pH}$ Diagrams to the Study of Specific Problems in Marine Geochemistry.” Aquatic Geochemistry, 227-248.

Glaus MA, W Hummel, and LR Van Loon. 2000. “Trace Metal-Humate Interactions. I. Experimental Determination of Conditional Stability Constants." Applied Geochemistry, 15:953-973.

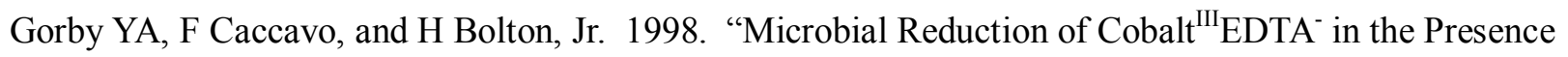
and Absence of Manganese(IV) Oxide.” Environmental Science and Technology, 32:244-250.

Hamilton EI. 1994. "The Geochemistry of Cobalt.” The Science of the Total Environment, 150:7-39.

Harmsen RW and WW Schulz. 1998. Best-Basis Estimates of Solubility of Selected Radionuclide in Hanford Single-Shell Tank Sludge. HNF-3271, Lockheed Martin Hanford Corporation, Richland, Washington.

Harter RD. 1992. "Competitive Sorption of Cobalt, Copper, Nickel Ions by a Calcium-Saturated Soil." Soil Science Society of America Journal, 56:444-449. 
PNNL-14126

Hem JD. 1985. Study and Interpretation of the Chemical Characteristics of Natural Water. U.S. Geological Survey Water Supply Paper 2254, U.S. Geological Survey, Alexandria, Virginia.

Hem JD, CE Roberson, and CJ Lind. 1985. "Thermodynamic Stability of CoOOH and Its Coprecipitation with Manganese.” Geochimica et Cosmochimica Acta, 49:801-810.

Jardine PM and DL Taylor. 1995. "Kinetics and Mechanisms of Co(III)EDTA Oxidation by Pyrolusite." Geochimica et Cosmochimica Acta, 59:4193-4203.

Jardine PM, GK Jacobs, and JD O’Dell. 1993. “Unsaturated Transport Processes in Undisturbed Heterogeneous Porous Media: II. Co-Contaminants.” Soil Science Society of America Journal, 57:954-962.

Jones TL, RJ Serne, and AP Toste. 1988. Special Waste-Form Lysimeters-Arid: Three-Year Monitoring Report. PNL-6400, Pacific Northwest Laboratory, Richland, Washington.

Kaplan DI, RJ Serne, and MG Piepho. 1995. Geochemical Factors Affecting Radionuclide Transport Through Near and Far Fields at a Low-Level Waste Disposal Site. Available Sorption Constants and Recommendations for Future Studies. PNL-10379, Pacific Northwest National Laboratory, Richland, Washington.

Kaplan DI, RJ Serne, AT Owen, J Conca, TW Wietsma, and TL Gervais. 1996. Radionuclide Adsorption Distribution Coefficients Measured in Hanford Sediments for the Low Level Waste Performance Assessment Project. PNNL-11485, Pacific Northwest Laboratory, Richland, Washington.

Katz LE and KF Hayes. 1995a. "Surface Complexation Modeling. 1. Strategy for Modeling Monomer Complex-Formation at Moderate Surface Coverage." Journal of Colloid and Interface Science, 170:477-490.

Katz LE and KF Hayes. 1995b. "Surface Complexation Modeling. 2. Strategy for Modeling Polymer and Precipitation Reactions at High Surface Coverage." Journal of Colloid and Interface Science, 170:491-501.

Kay JT, MH Conklin, CC Fuller, and PA O’Day. 2001. "Processes of Nickel and Cobalt Uptake by a Manganese Oxide Forming Sediment in Pinal Creek, Globe Mining, Arizona." Environmental Science and Technology, 35:4719-4725.

Khan SA, R-U-Rehman, and MA Khan. 1996. "Sorption of Cobalt on Bentonite." Journal of Radioanalytical and Nuclear Chemistry, Articles, 207:19-37.

Killey RWD, JO McHugh, DR Champ, EL Cooper, and JL Young. 1984. “Subsurface Cobalt-60 Migration from a Low-Level Waste Disposal Site.” Environmental Science and Technology, 18:146-157. 
Lowson RT and JV Evans. 1983. "Adsorption and Desorption of Low Concentrations Heavy Metal Ions on Oxides and Clays." In Environmental Migration of Radium and Other Contaminants Present in Liquid and Solid Wastes from the Mining and Milling of Uranium, JV Evans (manager), pg. 7(1)-7(11), Progress Report of the CRP, IAEA Research Contract No.2890/CF, Australian Atomic Energy Commission Research Establishment, Lucas Heights Research Laboratories, Sutherland, New South Wales, Australia.

McLaren RG, DM Lawson, and RS Swift. 1986. "Sorption and Desorption of Cobalt by Soils and Soil Components.” Journal of Soil Science, 37:413-426.

McLaren RG, CA Backes, AW Rate, and RS Swift. 1998. "Cadmium and Cobalt Desorption Kinetics from Soil Clays: Effect of Sorption Period.” Soil Science Society of America Journal, 62:332-337.

Means JL, DA Crerar, and JO Duguid. 1976. Chemical Mechanisms of ${ }^{60}$ Co Transport in Ground Water from Intermediate-Level Liquid Waste Trench 7: Progress Report for Period Ending June 30, 1975. ORNL/TM-5348, Oak Ridge National Laboratory, Oak Ridge, Tennessee.

Means JL, DA Crerar, and JO Duguid. 1978a. "Migration of Radioactive Wastes: Radionuclide Mobilization by Complexing Agents." Science, 200:14771481.

Means JL, DA Crerar, MP Borcsik, and JO Duguid. 1978b. "Adsorption of Co and Selected Actinides by Mn and Fe Oxides in Soils and Sediments." Geochimica et Cosmochimica Acta, 42:1763-1773.

O’Day P, GE Brown, Jr, and GA Parks. 1994a. "X-Ray Absorption Spectroscopy of Cobalt(II) Multinuclear Surface Complexes and Surface Precipitates on Kaolinite." Journal of Colloid and Interface Science, 165:269-289.

O’Day PA, GA Parks, and GE Brown, Jr. 1994b. “Molecular Structure and Binding Sites of Cobalt(II) Surface Complexes on Kaolinite from X-ray Absorption Spectroscopy." Clays and Clay Minerals, 42:337-355.

O’Day PA, CJ Chisholm-Brause, SN Towle, GA Parks, and GE Brown Jr. 1996. "X-ray Absorption Spectroscopy of Co(II) Sorption Complexes on Quartz $\left(\alpha-\mathrm{SiO}_{2}\right)$ and Rutile $\left(\mathrm{TiO}_{2}\right)$." Geochimica et Cosmochimica Acta, 60:2515-2532.

Olsen CR, PD Lowry, SY Lee, IL Larsen, and NH Cutshall. 1986. “Geochemical and Environmental Processes Affecting Radionuclide Migration from a Formerly Used Seepage Trench.” Geochimica et Cosmochimica Acta, 50:593-607.

Qian J, HB Xue, L Sigg, and A Albrecht. 1998. "Complexation of Cobalt by Natural Ligands." Environmental Science and Technology, 32:2043-2050.

Rose AW, HE Hawkes, and JS Webb. 1979. Geochemistry in Mineral Exploration. Academic Press, Second Edition, New York, New York. 
Routson RC, GS Barney, RM Smith, CH Delegard, and L Jensen. 1981. Fission Product Sorption Parameters for Hanford 200 Area Sediment Types. RHO-ST-35, Rockwell Hanford Operations, Richland, Washington.

Routson RC, GS Barney, CH Delegard, and RM Smith. 1987. "Trace Cobalt Sorption on 21 Sediment Types from the Hanford Site, Washington." Nuclear and Chemical Waste Management, 7:73-87.

Schell WR, AL Sanchez, DW Underhill, and E Thomas. 1986. "Natural Geochemical Repositories for Wastes: Field and Laboratory Measurements of Diffusion and Distribution Coefficients in Age Dated Peat Bogs." In Application of Distribution Coefficients to Radiological Assessment Models, TH Sibley and C Myttenaere (eds.), pp. 207-223, Elsevier Applied Science Publishers, New York, New York.

Serne RJ, JL Conca, VL LeGore, KJ Cantrell, CW Lindenmeier, JA Campbell, JE Amonette, and MI Wood. 1993. Solid Waste Leach Characteristics and Contaminant-Sediment Interactions. Volume 1: Batch Leach and Adsorption Tests and Sediment Characterization. PNL-8889, Volume 1, Pacific Northwest Laboratory, Richland, Washington.

Serne RJ, AR Felmy, KJ Cantrell, KM Krupka, JA Campbell, H Bolton, Jr., and JK Fredrickson. 1996. Characterization of Radionuclide-Chelating Agent Complexes Found in Low-Level Radioactive Decontamination Waste. Literature Review. NUREG/CR-6124 (PNL-8856), Pacific Northwest National Laboratory, Richland, Washington.

Smith RM, AE Martell, and RJ Motekaitis. 1997. NIST Critically Selected Stability Constants of Metal Complexes Database. Version 4.0. NIST Standard Reference Database 46, National Institute of Standards and Technology, Gaithersburg, Maryland. (includes personal computer software database)

Szecsody JE, JM Zachara, and PL Bruckhart. 1994. "Adsorption-Dissolution Reactions Affecting the Distribution and Stability of Co IIEDTA in Iron Oxide-Coated Sand." Environmental Science and Technology, 28:1706-1716.

Szecsody JE, JM Zachara, A Chilakapati, PM Jarine, and AS Ferrency. 1998. "Importance of Flow and Particle-Scale Heterogeneity on Co ${ }^{\mathrm{II} / I I I}$ EDTA Reactive Transport." Journal of Hydrology, 209:112-136.

Thompson HA, GA Parks, and GE Brown, Jr. 1999. "Dynamic Interactions of Dissolution, Surface Adsorption, and Precipitation in an Aging Cobalt(II)-Clay-Water System." Geochimica et Cosmochimica Acta, 63:1767-1779.

Towle SN, JR Bargar, GE Brown, Jr., and GA Parks. 1997. "Surface Precipitation of Co(II)(aq) on $\mathrm{Al}_{2} \mathrm{O}_{3}$." Journal of Colloid and Interface Science, 187:62-82.

Wagman DD, WH Evans, VB Parker, RH Shumm, I Halow, SM Bailey, KL Churney, and RL Nuttall. 1982. "The NBS Tables of Chemical Thermodynamic Properties. Selected Values for Inorganic and $\mathrm{C}_{1}$ and $\mathrm{C}_{2}$ Organic Substances in SI Units." Journal of Physical and Chemical Reference Data, 11(Supplement No. 2):1-392. 
Wilding MW and DW Rhodes. 1963. Removal of Radioisotopes from Solution by Earth Materials from Eastern Idaho. IDO-14624, U.S. Atomic Energy Commission (Idaho Operations Office), Idaho Falls, Idaho.

Xu N, MF Hochella, Jr, GE Brown, Jr, and GA Parks. 1996. “Co(II) Sorption at the Calcite-Water Interface: I. X-ray Photoelectron Spectroscopic Study." Geochimica et Cosmochimica Acta, 60:2801-2815.

Zachara JM, CT Resch, and SC Smith. 1994. "Influence of Humic Substances on $\mathrm{Co}^{2+}$ Sorption by a Subsurface Mineral Separate and Its Mineralogic Components." Geochimica et Cosmochimica Acta, 58:553-566.

Zachara JM, SC Smith, and LS Kuzel. 1995a. "Adsorption and Dissociation of Co-EDTA Complexes in Iron Oxide-Containing Surface Sands.” Geochimica et Cosmochimica Acta, 59:4825-4844.

Zachara JM, PL Gassman, SC Smith, and D Taylor. 1995b. "Oxidation and Adsorption of Co(II)EDTA ${ }^{2-}$ Complexes in Surface Materials with Iron and Manganese Oxide Grain Coatings." Geochimica et Cosmochimica Acta, 59:4449-4463.

Zachara JM, SC Smith, and JK Fredrickson. 2000. "The Effect of Biogenic Fe(II) on the Stability and Sorption of Co(II)EDTA ${ }^{2-}$ to Goethite and a Subsurface Sediment." Geochimica et Cosmochimica Acta, 64:1345-1362.

Zachara JM, JK Fredrickson, SC Smith, and PL Gassman. 2001. "Solubilization of Fe(III) Oxide-Bound Trace Metals by a Dissimilatory Fe(III) Reducing Bacterium." Geochimica et Cosmochimica Acta, 65:75-93. 
PNNL-14126

\subsection{Europium}

Europium (Eu) (atomic number 63) is a member of the lanthanide series of transition metals in Group IIIB of the periodic classification of the elements. This series includes the element group known as the rare earth elements (REE), which includes elements with atomic numbers 58 to 71 . The europium isotopes of primary interest to waste disposal and site remediation activities at the Hanford Site include ${ }^{154} \mathrm{Eu}$ and ${ }^{155} \mathrm{Eu}$, which are all products of the fission of ${ }^{235} \mathrm{U}$. The half lives $\left(\mathrm{t}_{\mathrm{t} / 2}\right)$ of the ${ }^{154} \mathrm{Eu}$ and ${ }^{155} \mathrm{Eu}$ are 8.592 and 4.7611 years, respectively.

Considerable attention has been given to the geochemical behavior of europium and the other rare earth elements. Because of the unique chemical behavior of this series of elements, the rare-earth elements have been used extensively for tracers by mineralogists, petrologists, and cosmochemists in the study and theory of the origin and formation of rocks. These topics are discussed in detail in the compilation of review papers presented on the geochemistry and mineralogy of rare earth elements in Lipin and McKay (1989). During the past 20 or more years, the geochemical behavior of europium and the other rare-earth elements in aqueous solutions have also been investigated extensively due to their importance to the disposal of nuclear waste. Rare-earth elements are produced in significant quantities as a result of the fission of uranium and plutonium reactor fuels (Rard 1985). In addition, the use of europium and the other rare earth elements as analogues in the study the geochemical behavior of trivalent actinide elements, such as Am(III) and Cm(III), is well accepted (Choppin 1989; Krauskopf 1986). The general geochemical properties and abundances of the rare earth elements are summarized by Henderson (1984) and others. The aqueous geochemistry of the rare earth elements, including europium, is reviewed by Hass et al. (1995), Wood (1990), Brookins (1989), and others. The general geochemical processes affecting the mobility of europium in soil and rock systems are described by Ames and Rai (1978).

\subsection{Oxidation States}

The most stable oxidation state for elements in the lanthanide series, including europium, is +3 . For some lanthanides, such as europium, other oxidation states are known, but these are less stable. Samarium (Sm), europium, thulium (Tm), and ytterbium ( $\mathrm{Yb}$ ), for example, may also exist in the +2 oxidation state to a limited extent under very reducing conditions (Rard 1985). Of these four elements, europium is the only lanthanide for which the +2 oxidation state is sufficiently stable under natural conditions to affect its mineralogy and aqueous chemistry (Rard 1985).

Figure 4.1 is an Eh-pH diagram for the hydrolysis of europium based on currently available thermodynamic data. The diagram was calculated for a total concentration of europium of $10^{-15} \mathrm{~mol} / \mathrm{L}$ $\left(\sim 1.5 \times 10^{-10} \mathrm{mg} / \mathrm{L}\right)$ in the absence of dissolved complexing ligands other than hydroxide. Because there is no drinking water standard (DWS) for europium isotopes, an europium concentration similar to the interim DWS for ${ }^{125} \mathrm{Sb}$ (Section 2.2) was arbitrarily selected for calculation of this Eh-pH diagram. 
PNNL-14126

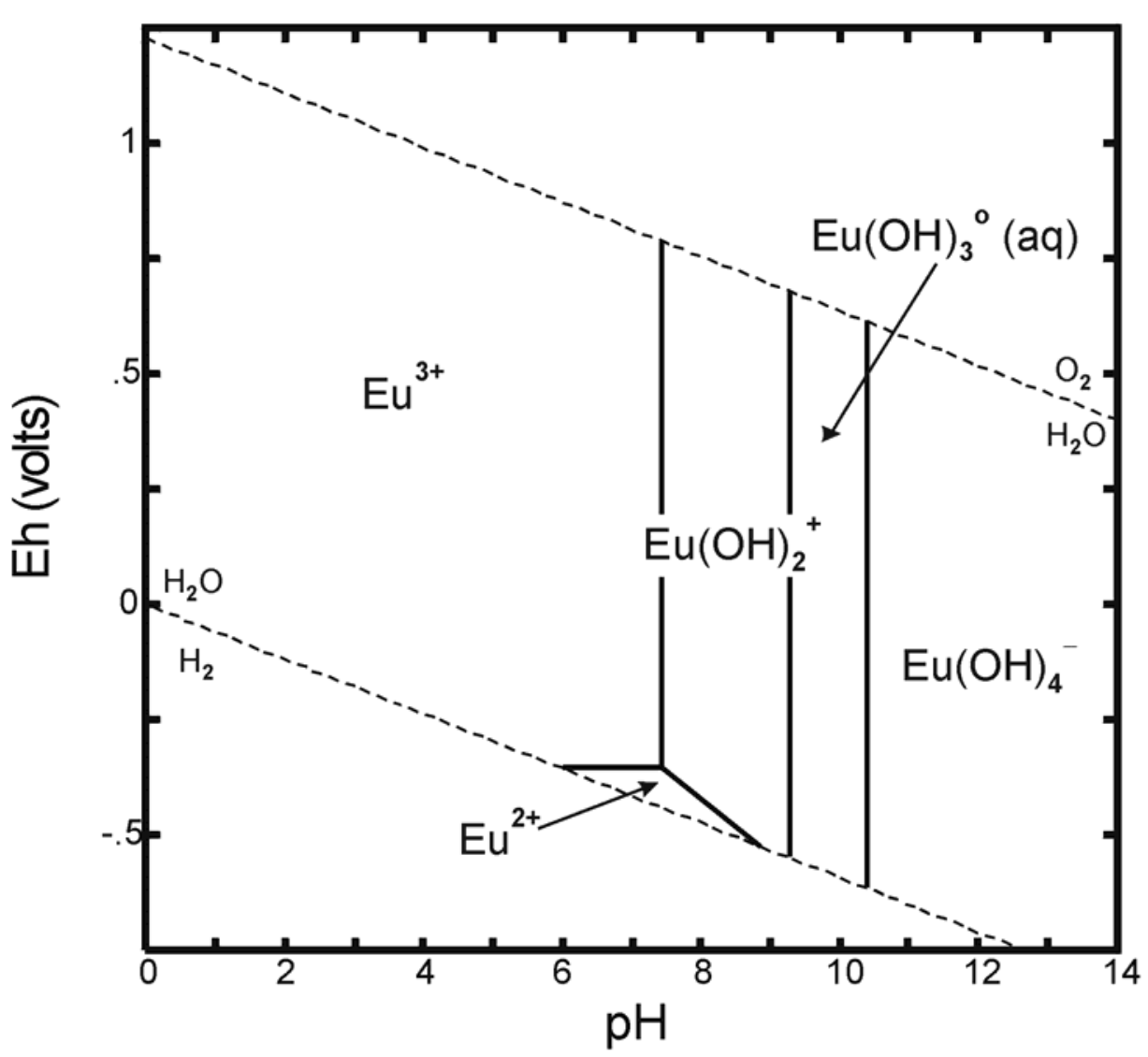

Figure 4.1. Eh-pH Diagram Showing the Hydrolysis of Eu(III) and $E u(I I)$ in the Absence of Other Complexing Ligands [Diagram was calculated at $25^{\circ} \mathrm{C}$ and a concentration of $10^{-15} \mathrm{~mol} / \mathrm{L}$ total dissolved europium.]

Based on equilibrium considerations, Figure 4.1 shows that the +3 oxidation state of europium dominates nearly the entire Eh-pH range for the thermodynamic stability of water at $25^{\circ} \mathrm{C}$. The stability region for $\mathrm{Eu}(\mathrm{II})$ is restricted to a small $\mathrm{Eh}-\mathrm{pH}$ region at circumneutral $\mathrm{pH}$ at very reducing conditions near the 1-atm boundary for the breakdown of water to $\mathrm{H}_{2}$ gas. Given the restricted $\mathrm{pH}$-Eh range calculated for the stability for $\mathrm{Eu}(\mathrm{II})$ and the lack of information available regarding the environmental behavior of $\mathrm{Eu}(\mathrm{II})$, there will be no further discussion of $\mathrm{Eu}(\mathrm{II})$ in this report. However, Figure 4.1 may underestimate the importance of $\mathrm{Eu}$ (II) if the available thermodynamic data for the $\mathrm{Eu}(\mathrm{III}) / \mathrm{Eu}$ (II) redox couple and/or $\mathrm{Eu}(\mathrm{II})$ aqueous complexes are drastically incorrect and/or incomplete.

The following sections will focus on the aqueous chemistry, solubility, and sorption behavior of $\mathrm{Eu}(\mathrm{III})$. Essentially no information is available for the aqueous geochemistry and environmental behavior of $\mathrm{Eu}(\mathrm{II})$. Under reducing geological conditions, the $\mathrm{Eu}^{+2}$ ion will likely have a geochemical behavior similar to $\mathrm{Sr}^{+2}$, and substitute for $\mathrm{Ca}^{+2}$ in minerals. The formation of $\mathrm{Eu}$ (II) is thought to be responsible 
for the well-known negative europium anomaly ${ }^{\mathrm{a}}$ (Carmichael et al. 1974). Substitution of $\mathrm{Eu}^{+2}{\text { and } \mathrm{Sr}^{+2}}^{+2}$ for $\mathrm{Ca}^{+2}$ in minerals during rock formation is expected given the similarities in their ionic radii, and has been documented [see reviews in Lipin and McKay (1989)]. The ionic radii for $\mathrm{Eu}^{+2}, \mathrm{Sr}^{+2}$, and $\mathrm{Ca}^{+2}$ in eight-fold coordination are 1.25, 1.26, and $1.12 \AA$, respectively (Shannon 1976).

\subsection{Aqueous Speciation}

The aqueous speciation of europium and the lanthanide elements has been reviewed extensively. Hass et al. (1995), Wood (1990), and others have examined the aqueous speciation of the lanthanide elements and their inorganic complexes and associated thermodynamic constants. Rard (1985) completed an extensive, critical review (includes 343 references) of the chemistry and thermodynamic properties of europium and its inorganic compounds and aqueous species. The aqueous chemistry of $\mathrm{Eu}(\mathrm{III})$ is generally consistent with the trends for the speciation of the other +3 rare earth elements. Lanthanide elements in the +3 oxidation state form stable complexes with oxygen-donor ligands, especially chelating agents (Baes and Mesmer 1976). Europium(III) forms strong complexes with dissolved hydroxide, sulfate, carbonate, phosphate, and fluoride, and weak complexes with dissolved chloride and nitrate (Wood 1990). Aqueous complexes of Eu(III) with dissolved sulfide and cyanide are expected to be very weak or nonexistent.

The dominant uncomplexed and hydrolytic species of $\mathrm{Eu}(\mathrm{III})$ and $\mathrm{Eu}(\mathrm{II})$ are shown as a function of Eh and $\mathrm{pH}$ in Figure 4.1. The hydrolysis of Eu(III) does not become appreciable until $\mathrm{pH}$ values are greater than 7. Above $\mathrm{pH} 7$, the hydrolysis of $\mathrm{Eu}(\mathrm{III})$ consists of the species $\mathrm{Eu}(\mathrm{OH})_{2}{ }^{+}, \mathrm{Eu}(\mathrm{OH})_{3}{ }^{\circ}(\mathrm{aq})$, and $\mathrm{Eu}(\mathrm{OH})_{4}{ }^{-}$with increasing $\mathrm{pH}$. Evidence exists that polynuclear as well as mononuclear $\mathrm{Eu}(\mathrm{III})$ hydroxide complexes may also present (Baes and Mesmer 1976). It should be noted that some speciation databases for europium includes the species $\mathrm{EuO}_{2}{ }^{-}$. From thermodynamic considerations, the aqueous species $\mathrm{Eu}(\mathrm{OH})_{4}{ }^{-}$is equivalent to $\mathrm{EuO}_{2}^{-}$plus $2 \mathrm{H}_{2} \mathrm{O}$ (liquid).

Figure 4.2 shows the Eh-pH diagram for the dominant europium aqueous species calculated for total concentrations of dissolved chloride, nitrate, and carbonate of $22,1.7$, and $67.5 \mathrm{mg} / \mathrm{L}$, respectively, in the absence of dissolved sulfate. The concentrations selected for these ligands are based on a composition for uncontaminated groundwater from the Hanford Site listed by Kaplan et al. (1996). ${ }^{\mathrm{b}}$ Like Figure 4.1, the dominant $\mathrm{Eu}(\mathrm{III})$ aqueous species predicted at acidic $\mathrm{pH}$ values is the uncomplexed ion $\mathrm{Eu}^{3+}$. However, at $\mathrm{pH}$ values from 5 to greater than 13, Figure 4.2 clearly indicates that aqueous carbonate species dominate the complexation of $\mathrm{Eu}(\mathrm{III})$ under these conditions based on the available thermodynamic data. The formation of $\mathrm{Eu}(\mathrm{III})$ carbonate complexes also pinches out the small stability field predicted for $\mathrm{Eu}^{2+}$ as seen in Figure 4.1. With the addition of $108 \mathrm{mg} / \mathrm{L}$ of dissolved sulfate, Eh-pH calculations indicate that the $\mathrm{Eu}(\mathrm{III})$ sulfate complex $\mathrm{EuSO}_{4}{ }^{+}$will replace $\mathrm{Eu}^{3+}$ as the dominant $\mathrm{Eu}(\mathrm{III})$ aqueous species at acidic $\mathrm{pH}$ conditions (Figure 4.3).

a The negative europium anomaly refers to the situation where the composition of an igneous melt has a strong depletion in europium with respect to other rare earth elements (Carmichael et al. 1974). The depletion results from fractional crystallization of plagioclase in which $\mathrm{Eu}^{2+}$ has substituted for $\mathrm{Ca}^{2+}$.

b The composition listed by Kaplan et al. (1996) for uncontaminated groundwater from the Hanford Site also includes $108 \mathrm{mg} / \mathrm{L}$ of dissolved sulfate. 
PNNL-14126

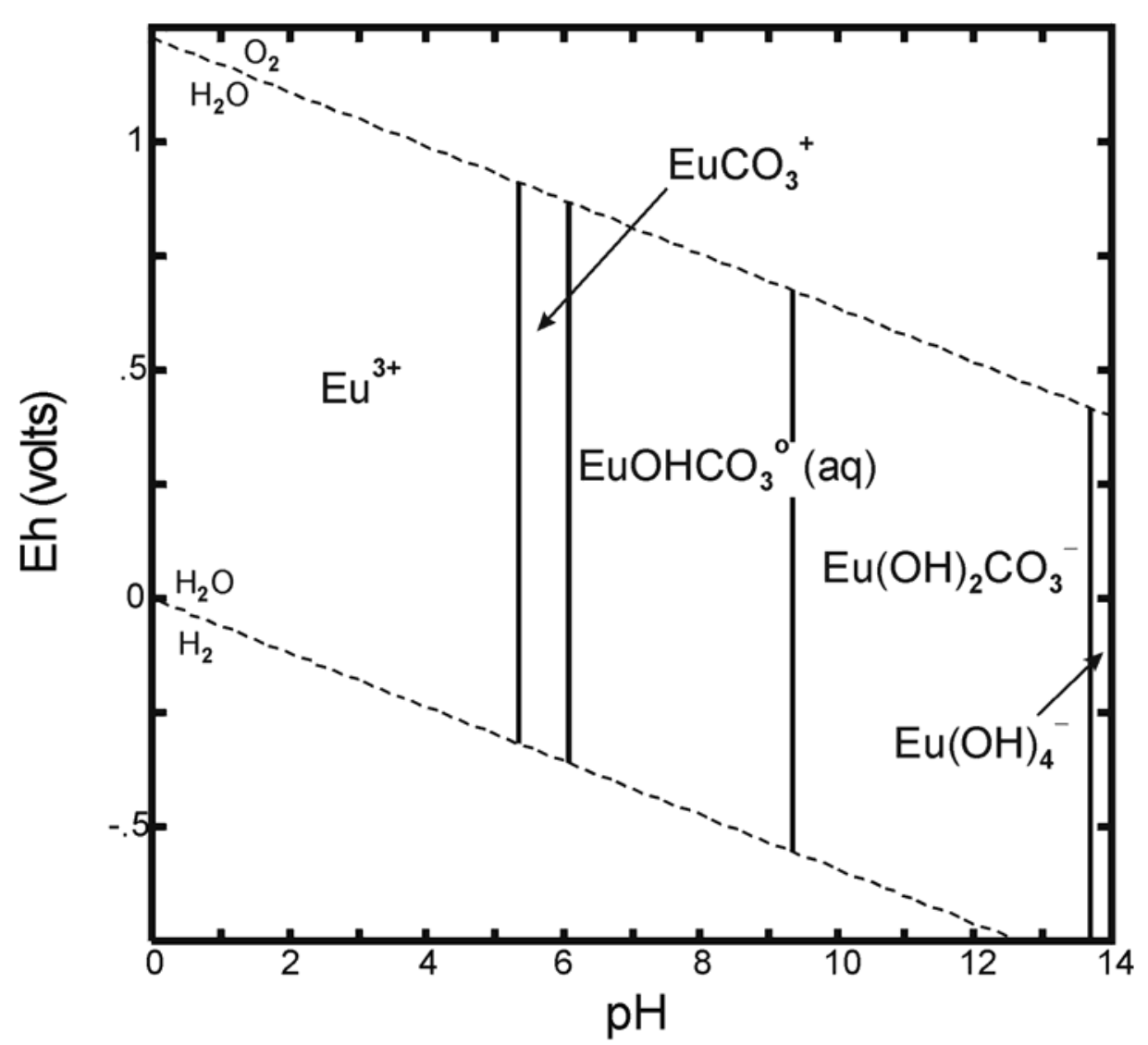

Figure 4.2. Eh-pH Diagram Showing the Dominant Aqueous Complexes of Europium [Diagram was calculated at $25^{\circ} \mathrm{C}$ and a concentration of $10^{-15} \mathrm{~mol} / \mathrm{L}$ total dissolved europium in the presence of dissolved chloride, nitrate, and carbonate.]

The concentrations (log molal) of the individual Eu(III) species calculated from available thermodynamic data are plotted in Figure 4.4 as a function of $\mathrm{pH}$ for an aqueous solution having the same composition of that used for Figure 4.3. Figure 4.4 also clearly shows that carbonate complexes should dominate the aqueous speciation of $\mathrm{Eu}(\mathrm{III})$ over a wide range of alkaline $\mathrm{pH}$ values. Moreover, at $\mathrm{pH}$ values greater than 9, the dominant $\mathrm{Eu}(\mathrm{III})$ aqueous species should be anionic, such as $\mathrm{Eu}(\mathrm{OH})_{2} \mathrm{CO}_{3}{ }^{-}$and $\mathrm{Eu}(\mathrm{OH})_{4}{ }^{-}$, based on thermodynamic considerations. Rard (1985) suggests that $\mathrm{Eu}(\mathrm{OH})_{4}{ }^{-}$does not likely form to a significant extent, because by analogy, the solubility of $\mathrm{Gd}(\mathrm{OH})_{3}$ increases only fourfold in $18.8 \mathrm{~mol} / \mathrm{L} \mathrm{NaOH}$ and the solubility of $\mathrm{La}(\mathrm{OH})_{3}$ varies even less with increases in the concentrations of dissolved base. As will be discussed in Section 4.5, the existence of such anionic hydroxide and carbonate species at alkaline $\mathrm{pH}$ values, as also in the case with antimony (Section 2), $\mathrm{Tc}(\mathrm{VII})$ (pertechnetate) (Section 4), and U(VI) (Section 5), should result in increased mobility of Eu(III) in the geochemical environment. Such mobility however is inconsistent with the observed sorption behavior of europium. 
PNNL-14126

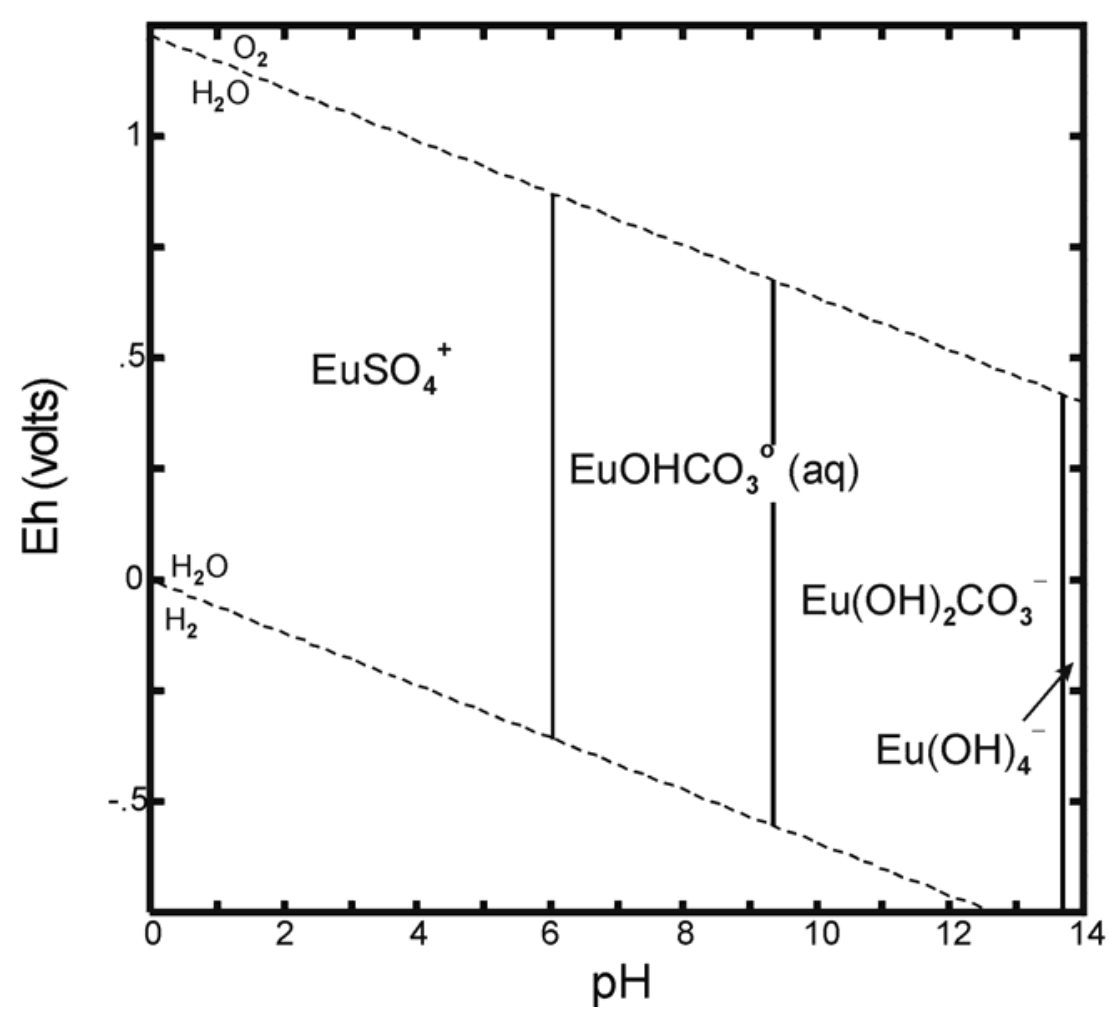

Figure 4.3. Eh-pH Diagram Showing the Dominant Aqueous Complexes of Europium [Diagram was calculated at $25^{\circ} \mathrm{C}$ and a concentration of $10^{-15} \mathrm{~mol} / \mathrm{L}$ total dissolved europium in the presence of dissolved sulfate, chloride, nitrate, and carbonate.]

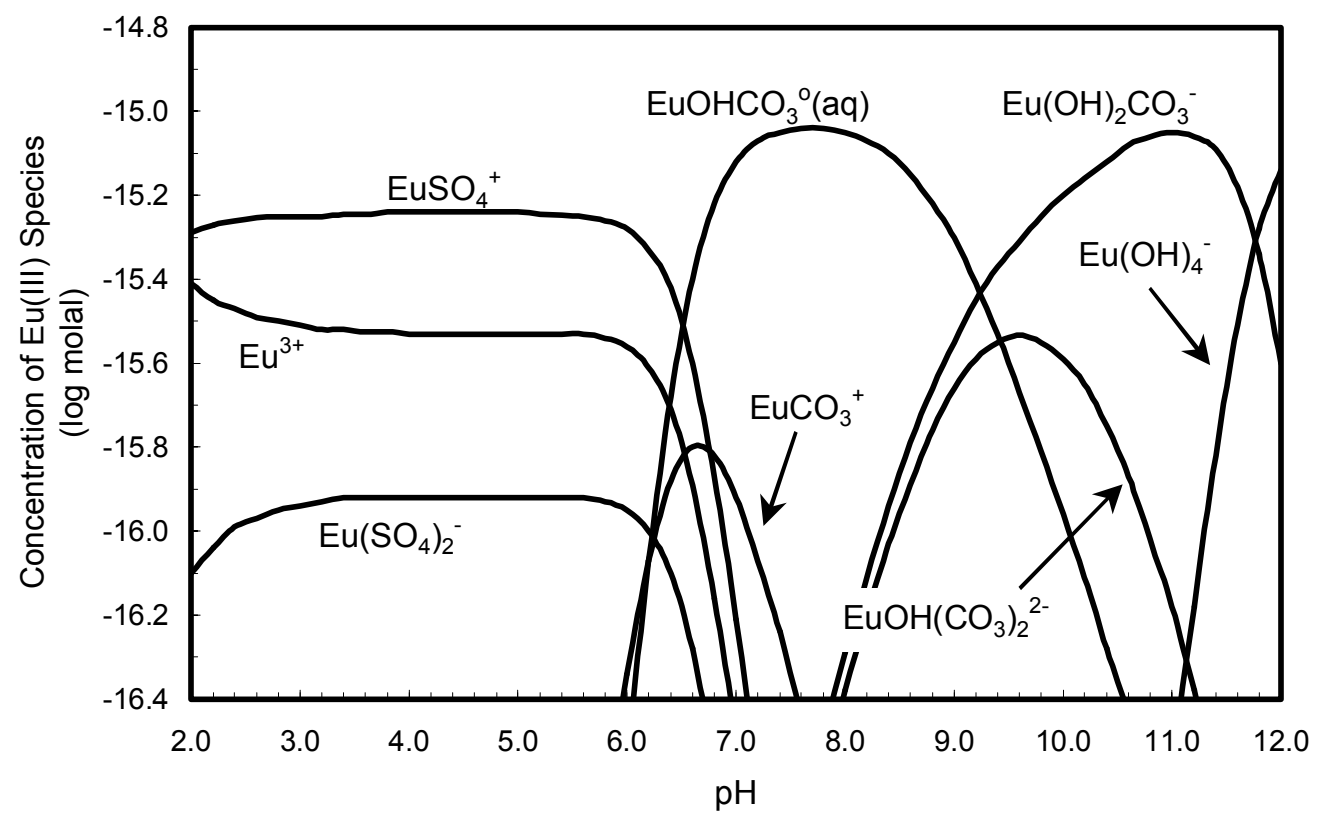

Figure 4.4. Concentrations (log molal) of Eu(III) Aqueous Complexes as a Function of $\mathrm{pH}$ [Diagram was calculated at $25^{\circ} \mathrm{C}$ and a concentration of $10^{-15} \mathrm{~mol} / \mathrm{L}$ total dissolved europium in the presence of dissolved sulfate, chloride, nitrate, and carbonate.] 
PNNL-14126

\subsection{Solubility Limits}

Europium(III) is considered very insoluble in environmental systems. Its low solubility may be a contributing factor to the large partition coefficient, $\mathrm{K}_{\mathrm{d}}$, values that have been experimentally determined for europium (Section 4.4). Over 26 europium-bearing minerals are known. ${ }^{\text {a }}$ Most of these minerals are silicates, oxides, and carbonates that have complex compositions. The europium occurs in these minerals in solid solution with other rare earth elements as well as with some alkaline-earth elements, such as calcium and strontium. ${ }^{\mathrm{b}}$ During the completion of this review, no solubility studies or thermodynamic data were identified that could be used to predict the aqueous stability of these europium-bearing minerals as a function of $\mathrm{pH}, \mathrm{Eh}$, and/or dissolved carbonate.

Rare earth elements may form several insoluble fluoride, oxalate, basic halides, and basic carbonates, as well as hydroxides (Baes and Mesmer 1976). Europium(III) may exist as a primary component in several oxides, hydroxides, halides, hydroxyhalides, oxyhalides, sulfides, phosphates, carbonates, sulfates, and nitrates (Rard 1985). Ames and Rai (1978) calculated the stabilities of several europium solids, including $\mathrm{EuO}, \mathrm{Eu}_{2} \mathrm{O}_{3}, \mathrm{Eu}_{3} \mathrm{O}_{4}, \mathrm{Eu}(\mathrm{OH})_{3}, \mathrm{EuCl}_{3} \cdot 6 \mathrm{H}_{2} \mathrm{O}$, and $\mathrm{Eu}_{2}\left(\mathrm{SO}_{4}\right)_{3} \cdot 8 \mathrm{H}_{2} \mathrm{O}$, as a function of $\mathrm{pH}$. The results of their calculations show that the solubilities of all of these europium solids, except for $\mathrm{Eu}(\mathrm{OH})_{3}$, are too high to control the concentrations of dissolved europium in environmental systems in the $\mathrm{pH}$ range from 4 to 10 . Of the solids and conditions considered by Ames and Rai (1978), $\mathrm{Eu}(\mathrm{OH})_{3}$ was the only likely solubility control for europium, and was most stable under alkaline conditions. Based on Figure 3-10 in Ames and Rai (1978), the estimated log stability constant, $\log \mathrm{K}_{\mathrm{r}, 298}$, is -16.0 for the reaction $^{\mathrm{c}}$

$$
\mathrm{Eu}^{3+}+3 \mathrm{H}_{2} \mathrm{O}=\mathrm{Eu}(\mathrm{OH})_{3}+3 \mathrm{H}^{+} .
$$

It is assumed that the y-axis for Figure 3-10 in Ames and Rai (1978) refers to the log activity of the uncomplexed aqueous ion $\mathrm{Eu}^{3+}$, and not the log of the total concentration of dissolved europium. Citing the results of a unpublished 1976 laboratory study by Serne and Rai at the Pacific Northwest Laboratory, Ames and Rai (1978) note that the precipitation of $\mathrm{Eu}(\mathrm{OH})_{3}$ is rapid and a likely solubility control for dissolved europium in slightly acidic to alkaline solutions.

Figure 4.5 shows the predicted stability fields for a total concentration of $10^{-6} \mathrm{~mol} / \mathrm{L}$ dissolved europium and the concentrations of dissolved carbonate, chloride, and sulfate specified for the composition of an uncontaminated groundwater from the Hanford Site listed by Kaplan et al. (1996). The shaded regions in Figure 4.5 show the Eh-pH regions where the solubilities of the identified europium solids (given in italics font) are exceeded based on the available thermodynamic data. The calculations indicate that the solubility of $\mathrm{Eu}_{2}\left(\mathrm{CO}_{3}\right)_{3} \cdot 2 \mathrm{H}_{2} \mathrm{O}$ is exceeded and may precipitate over the approximate $\mathrm{pH}$ range from 5 to 8 under these conditions. The stability regions for the $\mathrm{Eu}_{2}\left(\mathrm{CO}_{3}\right)_{3} \cdot 2 \mathrm{H}_{2} \mathrm{O}$ and EuS solids will increase with increasing concentrations of total dissolved europium. Aqueous solutions containing a

a Statement based on a search of Web-based mineralogical database at http://webmineral.com/chemical.shtml

b The compositional relations among the minerals containing rare earth elements are reviewed by Burt (1989).

c It was assumed that the y-axis for Figure 3-10 in Ames and Rai (1978) refers to the log of the activity of the aqueous $\mathrm{Eu}^{3+}$ ion, and not the log of the total concentration of dissolved europium. 
total concentration of dissolved europium of less than $10^{-7} \mathrm{~mol} / \mathrm{L}$ are predicted under these conditions to be undersaturated with respect to all Eu(III) solids in the model's thermodynamic database, including $\mathrm{Eu}(\mathrm{OH})_{3}$.

Figure 4.5 shows, as in previous Eh-pH figures in Section 4, that carbonate complexation dominates the chemistry of dissolved $\mathrm{Eu}(\mathrm{III})$ at basic $\mathrm{pH}$ values based on the available thermodynamic data. In the absence of dissolved carbonate, thermodynamic calculations indicate that the solubility of $\mathrm{Eu}(\mathrm{OH})_{3}$ is exceeded at $10^{-8} \mathrm{~mol} / \mathrm{L}$ total dissolved europium in the $\mathrm{pH}$ region from approximately 8 to 11 . The $\log \mathrm{K}_{\mathrm{r}, 298}$ value given in the model's database for $\mathrm{Eu}(\mathrm{OH})_{3}$ is -15.3 , compared to the -16.0 estimated for the same reaction from Figure 3-10 in Ames and Rai (1978).

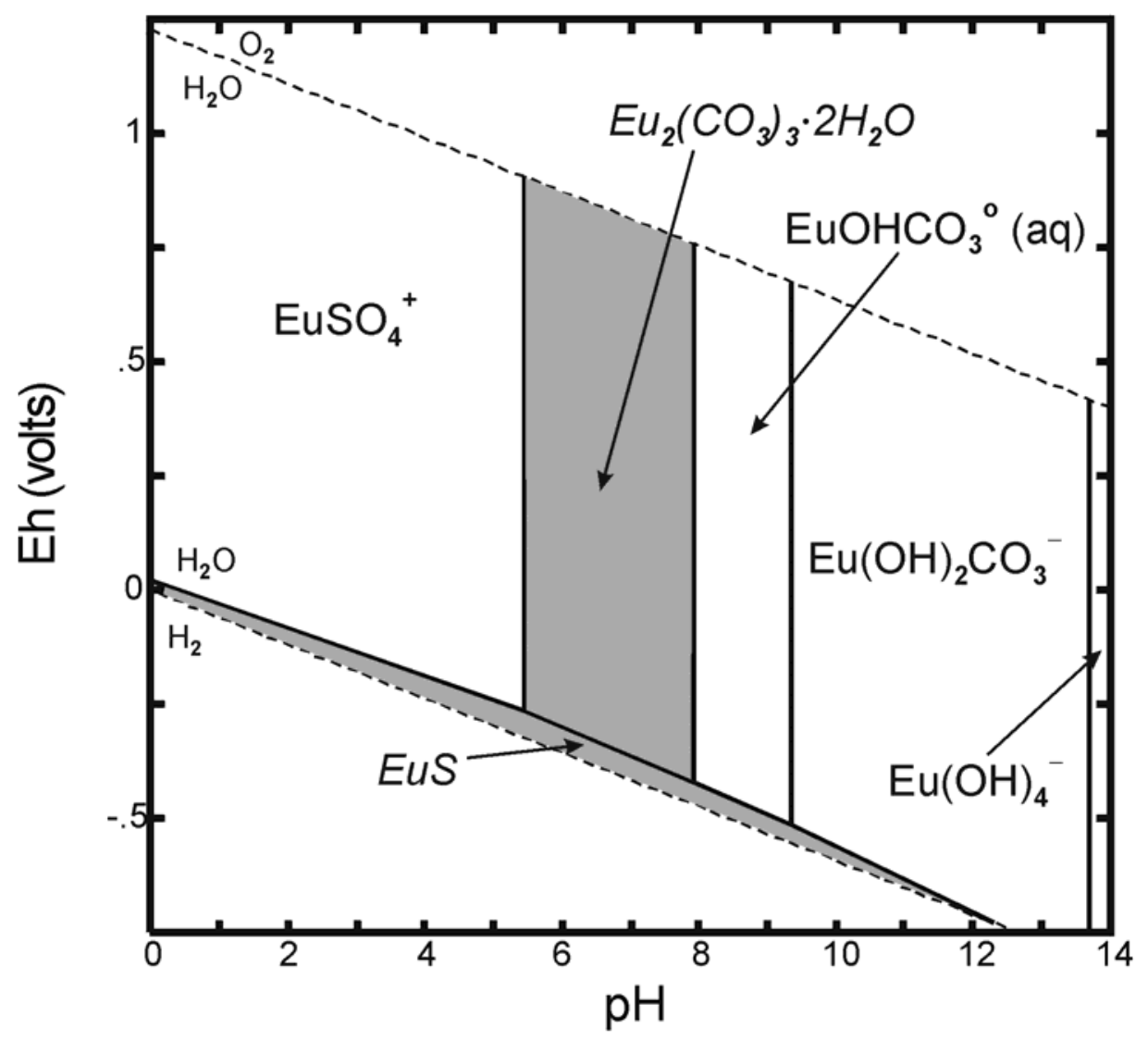

Figure 4.5. Eh-pH Diagram Showing the Stability Fields for the Dominant Europium Species at a Concentration of $10^{-6} \mathrm{~mol} / \mathrm{L}$ Total Dissolved Europium [Diagram was calculated at $25^{\circ} \mathrm{C}$ in the presence of dissolved sulfate, chloride, nitrate, and carbonate.]

\subsection{Adsorption}

The adsorption behavior of europium is similar to the other rare earth elements and trivalent actinides, such as Am(III) and Cm(III). Trivalent elements are considered to be highly sorbed in sediments (i.e., exhibit high $\mathrm{K}_{\mathrm{d}}$ values) and thus immobile in most environments (EPA 2003). The mobility of trivalent elements in the environment however, increases at acidic $\mathrm{pH}$ values and in high ionic strength 
solutions. Few studies were identified of europium adsorption on sediment samples from the Hanford Site. Because the geochemical behavior of europium is considered analogous to that of Am(III), the results of a few Am(III) adsorption studies will be discussed below to explain the expected adsorption behavior of europium. A detailed compilation of $\mathrm{Am}(\mathrm{III})$ and $\mathrm{Cm}(\mathrm{III})$ adsorption studies is presented in EPA (2003). It should be noted that because the concentrations of dissolved europium as well as Am(III) and $\mathrm{Cm}$ (III) may be controlled by solubility limits in some systems, some sorption measurements resulting in very high $\mathrm{K}_{\mathrm{d}}$ values may have been affected by europium precipitation reactions.

Clark et al. (1998) studied the adsorption of europium on an acidic sandy soil. As expected for dissolved cationic contaminants, europium adsorption was found to increase with increasing $\mathrm{pH}$, and was about $100 \%$ adsorbed at $\mathrm{pH}$ values of 5.5 and higher. Europium adsorption decreased with increasing ionic strength at low concentrations of total dissolved europium. Clark et al. (1998) also found that calcium was more effective than aluminum in competing with europium for adsorption on the sandy soil. Clark et al. (1998) suggested that ion exchange is an important sorption mechanisms for Eu(III), especially at $\mathrm{pH}$ values less than 4.5 .

Ames and Rai (1978) summarize the results of an unpublished 1976 laboratory study of europium precipitation and adsorption by Serne and Rai at the Pacific Northwest Laboratory. The $\mathrm{K}_{\mathrm{d}}$ measurements were conducted with "Burbank sand" using a range of $\mathrm{pH}$ values (final $\mathrm{pH}$ values from 4.75 to 5.32) and range of concentrations of dissolved europium that were less than that resulting in the precipitation of $\mathrm{Eu}(\mathrm{OH})_{3}$. Ames and Rai (1978) state that the adsorption measurements indicated the $\mathrm{K}_{\mathrm{d}}$ values for europium increased with increasing $\mathrm{pH}$ and decreased with increasing europium concentrations. The $\mathrm{K}_{\mathrm{d}}$ values ranged from $5.8 \mathrm{~mL} / \mathrm{g}$ (50.0 ppm europium at $\mathrm{pH} 4.88$ ) to $153 \mathrm{~mL} / \mathrm{g}$ (unspecified low europium concentration at $\mathrm{pH} 5.50)$.

Cantrell et al. (2002) compiled the $\mathrm{K}_{\mathrm{d}}$ values measured with Hanford sediments for radionuclides and other toxic constituents of environmental impact to the vadose zone and groundwater at the Hanford Site. Their compilation did not include adsorption data for europium or any of the other rare earth elements. For Am(III), Cantrell et al. (2002) include the results from the studies by Routson $(1975,1977)$ and Delegard and Barney (1983). Routson et al. $(1975,1977)$ used batch equilibration experiments to measure $\mathrm{K}_{\mathrm{d}}$ values for ${ }^{241} \mathrm{Am}$ on two soils as a function of the concentrations of dissolved calcium and sodium. The soil samples were selected to represent a range of weathering intensities. For arid conditions, a sandy (coarse-textured), low-exchange capacity soil was selected from a low rainfall area in eastern Washington. The $\mathrm{K}_{\mathrm{d}}$ values were measured in $0.002,0.02,0.05,0.10$, and $0.20 \mathrm{M} \mathrm{Ca}\left(\mathrm{NO}_{3}\right)_{2}$ solutions, and $0.015,0.030,0.30,0.75$, and $3.0 \mathrm{M} \mathrm{NaNO}_{3}$ solutions. The $\mathrm{pH}$ values of the ${ }^{241} \mathrm{Am}$ solutions in the calcium and sodium systems were 6.9 and 4.1 for the Washington soil, respectively. The $\mathrm{K}_{\mathrm{d}}$ values measured for the Washington soil ranged from 1,200 to $8,700 \mathrm{ml} / \mathrm{g}$, and were independent of the concentrations of dissolved calcium and sodium. Delegard and Barney (1983) measured $\mathrm{K}_{\mathrm{d}}$ for $\mathrm{Am}(\mathrm{III})$ in 1 and $4 \mathrm{M} \mathrm{NaOH}$ solutions containing different concentrations of chelating agents. In the absence of EDTA, large $\mathrm{K}_{\mathrm{d}}$ values were measured for Am(III) under highly basic conditions. The addition of 0.5 to $0.15 \mathrm{M}$ EDTA to the batch sorption experiments resulted in significantly reduced adsorption and thus low $\mathrm{K}_{\mathrm{d}}$ values.

Kaplan and Serne (2000) compiled a geochemical data package to support the performance assessment studies of immobilized low-activity tank wastes at the Hanford Site. For the "chemically 
impacted far field in sand sequence" environment, where the $\mathrm{pH}$ is in the range from 8 to 11, Kaplan and Serne (2000) suggested a range of $K_{d}$ values from 100 to $1,500 \mathrm{ml} / \mathrm{g}$ for the radionuclide group "Ac, Am, $\mathrm{Ce}, \mathrm{Cm}$, Eu." Their suggested range for $\mathrm{K}_{\mathrm{d}}$ values is based on the results of Routson et al. (1977).

Thibault et al. (1990) (also see Sheppard and Thibault, 1990) present a compilation of soil $\mathrm{K}_{\mathrm{d}}$ values prepared to support radionuclide migration assessments for a Canadian geologic repository for spent nuclear fuel in Precambrian Shield plutonic rock. Thibault et al. collected $\mathrm{K}_{\mathrm{d}}$ values from other compilations, journal articles, and government laboratory reports for important elements, such as americium, that would be present in the nuclear fuel waste inventory. The $\mathrm{K}_{\mathrm{d}}$ values listed in Thibault et al. (1990) for americium are 8.2 to $300,000 \mathrm{ml} / \mathrm{g}$ for sand, 400 to $48,309 \mathrm{ml} / \mathrm{g}$ for silt, 25 to $400,000 \mathrm{ml} / \mathrm{g}$ for clay, and 6,398 to $450,000 \mathrm{ml} / \mathrm{g}$ for organics. As discussed in EPA (1999), the variation observed in the literature for $\mathrm{K}_{\mathrm{d}}$ values for a contaminant is due to differences in sorption mechanisms, geochemical conditions, soil materials, and methods used for the measurements.

Because trivalent elements strongly adsorb to sediment particles, there is potential for colloidfacilitated transport of europium and other trivalent elements, such as Am(III), in vadose zone and groundwater systems. The reader is cautioned however, that the importance of colloid-facilitated migration, especially in environmental systems that do not involve fracture flow of pore water or groundwater, is still the subject of debate. Studies by Penrose et al. (1990) and Kaplan et al. (1994) have shown the potential importance of colloid-facilitated transport of Am(III) in sediment systems. Laboratory studies by Penrose et al. (1990) predicted that the movement of americium and plutonium would be limited to less than a few meters through a shallow aquifer within the site of the Los Alamos National Laboratory (LANL). However, both actinides were detected in monitoring wells as far as 3,390 $\mathrm{m}$ down gradient from the point source. Almost all of the americium and plutonium in the groundwater at the $3,390 \mathrm{~m}$ well were associated with colloids 0.025 to $0.45-\mu \mathrm{m}$ in diameter. Similarly, the results of laboratory measurements using site-specific soils and a two-phase solute transport code indicated that americium, curium, plutonium, and uranium would migrate less than $10 \mathrm{~m}$ in the F-Area of the Savannah River Site (Kaplan et al. 1994). The contaminants however, were found associated with groundwater colloids $1,200 \mathrm{~m}$ away from the point source.

\subsection{References}

Ames LL and D Rai. 1978. Radionuclide Interactions with Soil and Rock media. Volume 1: Processes Influencing Radionuclide Mobility and Retention, Element Chemistry and Geochemistry, and Conclusions and Evaluations. EPA 520/6-78-007-a, U.S. Environmental Protection Agency, Las Vegas, Nevada.

Baes CF, Jr and RF Mesmer. 1976. The Hydrolysis of Cations. John Wiley and Sons, New York, New York.

Brookins DG. 1989. "Aqueous Geochemistry of Rare Earth Elements.” In Reviews in Mineralogy. Volume 21. Geochemistry and Mineralogy of Rare Earth Elements, BR Lipin and GA Mckay (eds.), Chapter 8, pp. 201-205, Mineralogical Society of America, Washington, D.C. 
Burt DM. 1989. “Compositional and Phase Relations Among Rare Earth Element Minerals. In Reviews in Mineralogy. Volume 21. Geochemistry and Mineralogy of Rare Earth Elements, BR Lipin and GA Mckay (eds.), Chapter 8, pp. 259-307, Mineralogical Society of America, Washington, D.C.

Cantrell KJ, RJ Serne, and GV Last. 2002. Hanford Contaminant Distribution Coefficient Database and Users Guide. PNNL-13895, Pacific Northwest National Laboratory, Richland, Washington.

Carmichael ISE, FJ Turner, and J Verhoogen. 1974. Igneous Petrology. McGraw-Hill Book Company, New York, New York.

Clark SB, AL Bryce, AD Lueking, J Gariboldi, and SM Serkiz. 1998. "Factors Affecting Trivalent f-Element Adsorption to an Acidic Sandy Soil." In Adsorption of Metals by Geomedia. Variables, Mechanisms, and Model Applications, EA Jenne (ed.), pp. 149-164, Academic Press, San Diego, California.

Choppin GR. 1989. “'Soluble Rare Earth and Actinide Species in Seawater. Marine Chemistry, 28:19-26.

Delegard CH and GS Barney. 1983. Effects of Hanford High-Level Waste Components on Sorption of Cobalt, Strontium, Neptunium, Plutonium, ands Americium of Hanford Sediments. RHO-RE-ST-1 P, Rockwell Hanford Operations, Richland, Washington.

EPA(U.S. Environmental Protection Agency). 1999. Understanding Variation in Partition Coefficient, $K_{d}$, Values: Volume I. The $K_{d}$ Model, Methods of Measurement, and Application of Chemical Reaction Codes. EPA 402-R-99-04A, prepared for the U.S. Environmental Protection Agency, Washington, D.C. by Pacific Northwest National Laboratory, Richland, Washington.

EPA (U.S. Environmental Protection Agency). 2003 (in press). Understanding Variation in Partition Coefficient, Kd, Values: Volume III. Review of Geochemistry and Available $K_{d}$ Values for Americium, Arsenic, Curium, Iodine, Neptunium, Radium, and Technetium. EPA 402-R-99-004C, U.S. Environmental Protection Agency, Washington, D.C. prepared by KM Krupka and RJ Serne at the Pacific Northwest National Laboratory, Richland, Washington.

Haas JR, Shock, EL and Sassani, DC. 1995. "Rare Earth Elements in Hydrothermal Systems: Estimates of Standard Partial Molal Thermodynamic Properties of Aqueous Complexes of the Rare Earth Elements at High Pressures and Temperatures." Geochimica et Cosmochimica Acta, 59:4329-4350.

Henderson P. 1984. "General Geochemical Properties and Abundances of the Rare Earth Elements." In Rare Earth Geochemistry, P Henderson (ed.), pp. 1-32, Developments in Geochemistry 2, Elsevier, New York, New York.

Kaplan DI and RJ Serne. 2000. Geochemical Data Package for the Hanford Immobilized Low-Activity Tank Waste Performance Assessment (ILAW PA). PNNL-13037, Rev. 1, Pacific Northwest National Laboratory, Richland, Washington. 
PNNL-14126

Kaplan DI, RJ Serne, AT Owen, J Conca, TW Wietsma, and TL Gervais. 1996. Radionuclide Adsorption Distribution Coefficients Measured in Hanford Sediments for the Low Level Waste Performance Assessment Project. PNNL-11485, Pacific Northwest Laboratory, Richland, Washington.

Kaplan DI, PM Bertsch, DC Adriano, and KA Orlandini. 1994. "Actinide Association with Groundwater Colloids in a Coastal Plain Aquifer." Radiochimica Acta, 66/67:181-187.

Krauskopf KB. 1986. "Thorium and Rare-Earth Metals as Analogs for Actinide Elements.” Chemical Geology, 55:323-335.

Lipin BR and GA McKay (eds.). 1989. Reviews in Mineralogy. Volume 21. Geochemistry and Mineralogy of Rare Earth Element. Mineralogical Society of America, Washington, D.C.

Penrose WR, WL Polzer, EH Essington, DM Nelson, and KA Orlandini. 1990. "Mobility of Plutonium and Americium through a Shallow Aquifer in a Semiarid Region." Environmental Science and Technology, 24:228-234.

Rard JA. 1985. "Chemistry and Thermodynamics of Europium and Some if its Simpler Inorganic Compounds and Aqueous Species." Chemical Reviews, 85:555-582.

Routson RC, G Jansen, and AV Robinson. 1975. Sorption of ${ }^{99} \mathrm{Tc},{ }^{237} \mathrm{~Np}$ and ${ }^{241} \mathrm{Am}$ on Two Subsoils From Differing Weathering Intensity Areas. BNWL-1889, Pacific Northwest Laboratories, Richland, Washington.

Routson RC, G Jansen, and AV Robinson. 1977. “241 Am, ${ }^{237} \mathrm{~Np}$, and ${ }^{99} \mathrm{Tc}$ Sorption on Two United States Subsoils from Differing Weathering Intensity Areas.” Health Physics, 33:311-317.

Sheppard MI and DH Thibault. 1990. "Default Soil Solid/Liquid Partition Coefficients, $\mathrm{K}_{\mathrm{d}} \mathrm{s}$, for Four Major Soil Types: A Compendium." Health Physics, 59(4):471-482.

Shannon RD. 1976. "Revised Effective Ionic Radii and Systematic Studies of Interatomic Distances in Halides and Chalcogenides." Acta Crystallographica, A32:751-767.

Thibault DH, MI Sheppard, and PA Smith. 1990. A Critical Compilation and Review of Default Soil Solid/Liquid Partition Coefficients, $K_{d}$, for Use in Environmental Assessments. AECL-10125, Whiteshell

Wood SA. 1990. "The Aqueous Geochemistry of the Rare-Earth Elements and Yttrium. 1. Review of Available Low-Temperature Data for Inorganic Complexes and the Inorganic REE Speciation of Natural Waters." Chemical Geology, 82:159-186. 
PNNL-14126

\subsection{Technetium}

Technetium (Tc) (atomic number 43) is a member of Group VIIB in the periodic classification of the elements. Technetium-99 is the isotope of primary importance to waste disposal and site remediation activities at the Hanford Site. Technetium-99 is generated as a fission product during the irradiation of uranium-containing nuclear fuels, and has a half live $\left(\mathrm{t}_{1 / 2}\right)$ of $2.11 \times 10^{5} \mathrm{yr}$.

The behavior of technetium in environmental systems has been reviewed extensively by others. Reviews include Lieser (1993), Gu and Schulz (1991), Sparks and Long (1987), Meyer et al. (1985), Beasley and Lorz (1984), Coughtrey et al. (1983), Onishi et al. (1981), Wildung et al. (1979), Ames and Rai (1978), and others. Huges and Rossotti (1987) review in detail the solution chemistry of technetium. Dissolved technetium is present in oxic environmental systems as the aqueous $\mathrm{Tc}(\mathrm{VII})$ oxyanion species $\mathrm{TcO}_{4}{ }^{-}$. Technetium(VII) is essentially nonadsorptive (i.e., $\mathrm{K}_{\mathrm{d}}$ values are $\approx 0 \mathrm{ml} / \mathrm{g}$ ), highly soluble, and thus highly mobile under oxic conditions at neutral and basic $\mathrm{pH}$ values. Like most anions, the adsorption of $\mathrm{TcO}_{4}{ }^{-}$to geologic materials increases with decreasing $\mathrm{pH}$ at acidic $\mathrm{pH}$ conditions. However, under reducing soil and geologic conditions, technetium is expected to be reduced to the +4 valance state due to biotic and abiotic reactive processes, such as surface-mediated reduction of $\mathrm{Tc}(\mathrm{VII})$ by $\mathrm{Fe}(\mathrm{II})$.

Technetium(IV) is considered to be essentially immobile, because it is sparingly soluble and highly sorbed to iron and aluminum oxides and clays.

A considerable quantity of our knowledge on the coordination chemistry of technetium comes from development studies since the early 1960 s of ${ }^{99 \mathrm{~m}}$ Tc-labeled radiopharmaceuticals for medical imaging. Detailed reviews of the history and use of technetium in nuclear medicine have been published by Dilworth and Parrott (1998), Jones (1995), and others. The short-lived isomer ${ }^{99 \mathrm{~m}} \mathrm{Tc}$ has been used extensively for imaging in nuclear medicine due to its favorable decay properties. Technetium- $99 \mathrm{~m}$ has a short half life $\left(\mathrm{t}_{1 / 2}\right)$ of $6.01 \mathrm{hr}$, which is compatible with the duration of most imaging procedures. The radionuclide decays by a single $140 \mathrm{keV}$ photon, has relatively little nonpenetrating radiation, and decays to long-lived ${ }^{99} \mathrm{Tc}$ which is a low-energy beta emitter. Sufficient quantities of ${ }^{99 \mathrm{~m}} \mathrm{Tc}$ can therefore be administered for imaging while minimizing radiation doses. Research in this field has shown that reduced forms of ${ }^{99 \mathrm{~m}} \mathrm{Tc}$ have a strong affinity and may complex with phosphonate ligands, sulfur ligands, and some organic complexants such as DTPA. This research has focused on the development of ${ }^{99 \mathrm{~m}} \mathrm{Tc}$ complexes that concentrate in specific organs or through specific physiological functions. It appears that the results from the ${ }^{99 \mathrm{~m}} \mathrm{Tc}$ radiopharmaceutical studies have had little impact on improving our understanding of the environmental behavior of technetium.

\subsection{Oxidation States}

Technetium exists in valence states from +7 to -1 . In natural environments, the most stable valence states of technetium are +7 and +4 under oxidizing and reducing conditions, respectively. Other valence states are encountered chiefly in complex compounds (Mazzi 1989). The chemical behaviors of technetium in the +7 and +4 oxidation states differ drastically. In the +7 valence state, dissolved technetium exists as pertechnetate anion, $\mathrm{TcO}_{4}{ }^{-}$, over the complete $\mathrm{pH}$ range of natural waters. Because the pertechnetate anion is highly soluble and is not strongly sorbed at neutral and basic $\mathrm{pH}$ conditions, it 
is highly mobile in most oxidizing systems. In the +4 valence state, technetium exists as the tetravalent cation and is relatively immobile in the absence of strongly complexing ligands. Technetium(IV) is highly sorbed, and forms the sparingly soluble $\mathrm{TcO}_{2} \cdot \mathrm{nH}_{2} \mathrm{O}$ solid. The reduction of $\mathrm{Tc}$ (VII) to $\mathrm{Tc}$ (IV) by abiotic and biotic processes has recently been the subject of extensive studies, because it has a significant affect on the mobility of technetium in waste streams, vadose zones, sediments, and groundwaters. These reaction processes are the basis for certain remediation technologies, such as permeable barriers composed of zero-valent iron particles (i.e., as metallic iron) or sodium-dithionite reduced soils, which are currently being tested for immobilization of groundwater contaminants. Microbial reduction of Tc(VII) has also been suggested as a potential mechanism for removal of technetium from contaminated groundwaters and waste streams [e.g., Lovley $(1993,1995)]$. Certain dissimilatory metal reducing bacteria and sulfate reducing bacteria have been determined to be capable of coupling the oxidation of organic carbon or hydrogen to the reduction of Tc(VII) to Tc(IV) (Lloyd and Macaskie 1996; Lloyd et al. 1997, 1998, 1999, 2000; Wildung et al. 2000; Fredrickson et al. 2000).

\subsection{Aqueous Speciation}

Rard et al. (1999) have published an extensive, critical review of the thermodynamics of technetium. It is the most detailed review completed to date of the chemistry and available thermodynamic data for inorganic technetium compounds. Figure 5.1 is an Eh-pH diagram that shows the dominant aqueous hydrolytic species of technetium in the absence of dissolved ligands other than hydroxide. The diagram was calculated at $25^{\circ} \mathrm{C}$ using a concentration of $5.30 \times 10^{-5} \mathrm{mg} / \mathrm{L}\left(10^{-9.27} \mathrm{~mol} / \mathrm{L}\right)$ total dissolved technetium. This concentration corresponds to $900 \mathrm{pCi} / \mathrm{L}^{99} \mathrm{Tc}$. ${ }^{a}$ Under oxidizing conditions, the speciation of dissolved technetium is dominated by the pertechnetate oxyanion $\mathrm{TcO}_{4}{ }^{-}$. The $\mathrm{TcO}_{4}{ }^{-}$ion is stable over the complete $\mathrm{pH}$ range of natural waters, and is not known to form any strong aqueous complexes. Under reducing conditions in the absence of dissolved carbonate, technetium aqueous speciation is dominated at $\mathrm{pH}$ values greater than 2 by the neutral $\mathrm{Tc}(\mathrm{IV})$ species $\mathrm{TcO}(\mathrm{OH})_{2}{ }^{\mathrm{o}}$ (aq). Under extremely reducing conditions, the Eh-pH diagram suggests the possible formation of $\mathrm{Tc}^{3+}$ at $\mathrm{pH}$ values less than 2.

The reader should note that many of the species distribution and Eh-pH calculations presented in papers and reports published prior to the critical review by Rard et al. (1999) included the aqueous neutral dimer species $\left(\mathrm{TcO}(\mathrm{OH})_{2}\right)_{2}{ }^{\mathrm{o}}$ (aq). For many calculations, $\left(\mathrm{TcO}(\mathrm{OH})_{2}\right)_{2}{ }^{\mathrm{o}}$ (aq) was predicted to be the dominant $\mathrm{Tc}(\mathrm{IV})$ species at neutral and basic $\mathrm{pH}$ values instead of the monomer $\mathrm{TcO}(\mathrm{OH})_{2}{ }^{\mathrm{o}}(\mathrm{aq})$. Moreover, the calculated Eh-pH stability field for the dimer $\left(\mathrm{TcO}(\mathrm{OH})_{2}\right)_{2}{ }^{\mathrm{o}}$ (aq) increases with increasing concentration of dissolved Tc(IV) due to its stoichiometric factor. Rard et al. (1999) found it difficult to evaluate the results of the study on which the dimer species and associated thermodynamic constant were based, and therefore did not accept those results and the species $\left(\mathrm{TcO}(\mathrm{OH})_{2}\right)_{2}{ }^{\mathrm{o}}(\mathrm{aq})$ for their thermodynamic database for technetium compounds.

a The concentration of $900 \mathrm{pCi} / \mathrm{L}$ is the interim drinking water standard (DWS) for ${ }^{99} \mathrm{Tc}$. It is based on the concentration of ${ }^{99} \mathrm{Tc}$ that is assumed to yield an annual dose equivalent of $4 \mathrm{mrem} / \mathrm{yr}$. 
PNNL-14126

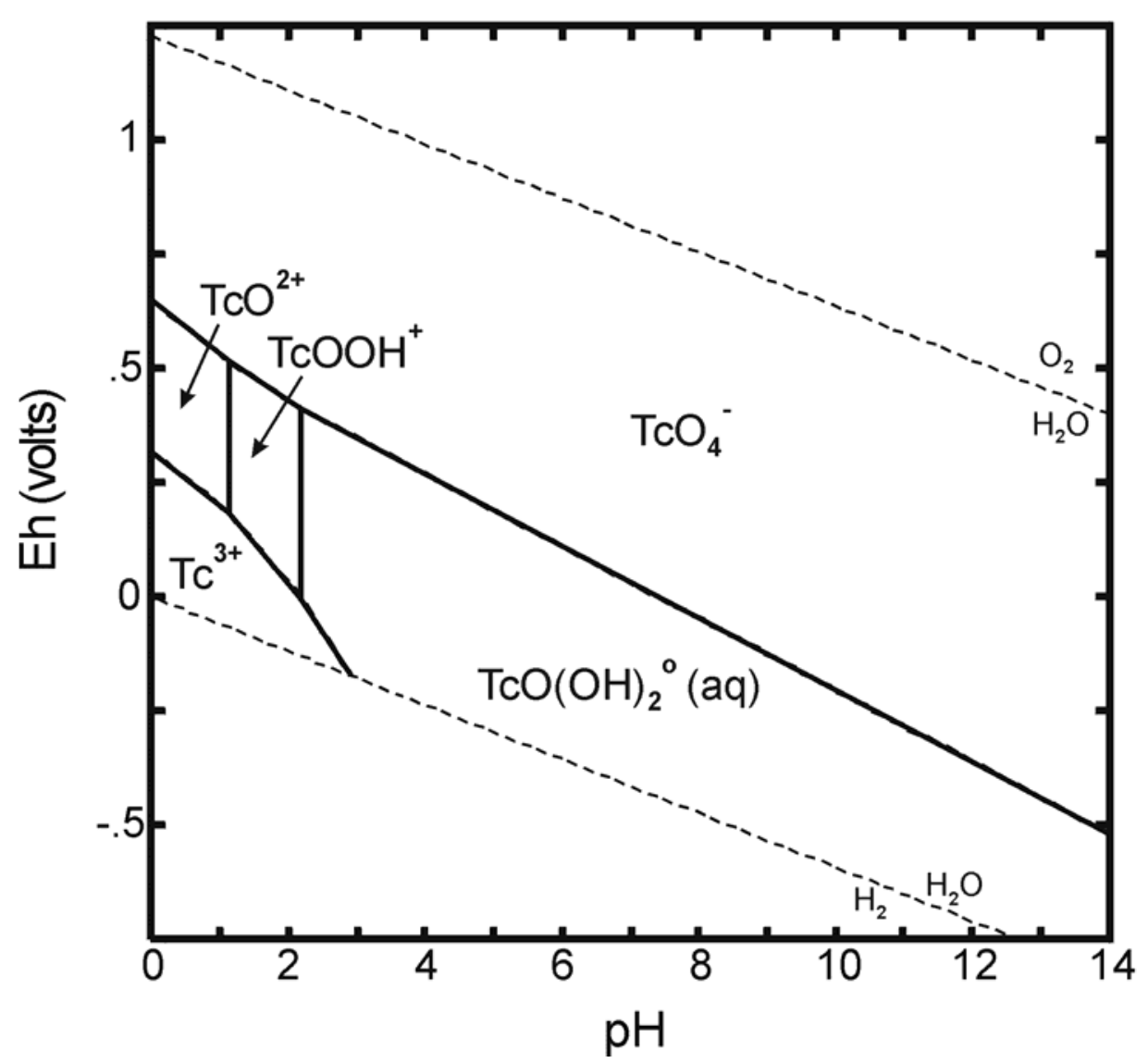

Figure 5.1. Eh-pH Diagram Showing Dominant Aqueous Species of Technetium in the Absence of Dissolved Carbonate [Diagram was calculated at $25{ }^{\circ} \mathrm{C}$ and a concentration of $5.30 \times 10^{5} \mathrm{mg} / \mathrm{L}\left(10^{-9.27} \mathrm{~mol} / \mathrm{L}\right)$ dissolved technetium.]

Although the thermodynamic stability of $\mathrm{TcO}_{4}{ }^{-}$is well established, thermodynamic data for other aqueous complexes and solids containing technetium in its various valence states are extremely limited. The absence of such data precludes the use of thermodynamic calculations to evaluate the potential impact to the environmental behavior of reduced species of dissolved technetium with respect to $\mathrm{pH}$, Eh, and the presence of important dissolved complexing ligands such as dissolved carbonate, phosphate, sulfate, chloride, and others. The Tc(IV) carbonate complexes $\mathrm{TcCO}_{3}(\mathrm{OH})_{2}{ }^{\mathrm{o}}(\mathrm{aq})$ and $\mathrm{TcCO}_{3}(\mathrm{OH})_{3}{ }^{-}$are the only non-hydrolytic aqueous complexes of technetium for which Rard et al. (1999) list Gibbs free energy of formation $\left(\Delta \mathrm{G}_{\mathrm{f}, 298^{\circ}}\right)$ values. The thermodynamic constants listed for $\mathrm{TcCO}_{3}(\mathrm{OH})_{2}{ }^{\circ}$ (aq) and $\mathrm{TcCO}_{3}(\mathrm{OH})_{3}{ }^{-}$are based on the solubility study of solid $\mathrm{TcO}_{2} \cdot \mathrm{xH}_{2} \mathrm{O}$ completed in presence and absence of $\mathrm{CO}_{2}$ (gas) by Eriksen et al. (1992). However, no independent measurements exist to verify the composition and thermodynamic properties of the Tc(IV) aqueous carbonate complexes.

Technetium(IV) carbonate complexes likely affect the aqueous speciation and solubility of Tc(IV) at near neutral and/or basic $\mathrm{pH}$ conditions. The results of other studies suggest the formation of $\mathrm{Tc}(\mathrm{IV})$ aqueous carbonate complexes. For example, Paquette and Lawrence (1985) reported spectrographic evidence for the formation of aqueous carbonate complexes with both $\mathrm{Tc}$ (III) and Tc(IV). Wildung et al. 
(2000) studied the effects of electron donor and the presence of dissolved bicarbonate on enzymatic reduction of Tc(VII) by the metal-reducing bacterium Shewanella putrefaciens CN32. Based on the results of experiments conducted in bicarbonate solutions, Wildung et al. (2000) proposed the formation of a soluble, negatively-charged Tc(IV) carbonate complex that exceeds Tc(VII) in electrophoretic mobility and possibly dominates the speciation of dissolved $\mathrm{Tc}(\mathrm{IV})$ over neutral and basic $\mathrm{pH}$ values. Given that anionic aqueous complexes do not readily adsorb to geologic materials under near neutral and basic $\mathrm{pH}$ conditions, Wildung et al. (2000) suggested that the formation of anionic $\mathrm{Tc}(\mathrm{IV})$ carbonate complex(es) may represent an important mechanism for technetium migration in reducing geochemical environments. Generally, it has been assumed that technetium mobility in reducing environments is limited by the low solubility of Tc(IV) hydrous oxide (see Section 5.3) and adsorption of aqueous Tc(IV) hydrolytic complexes. Given that dissolved carbonate is ubiquitous in surface and subsurface environments, further research is needed to determine the composition and thermodynamic properties of Tc(IV) carbonate complexes.

As noted in Section 1, the potential complexation of technetium by dissolved EDTA, HEDTA, NTA, citrate, hydroacetic acid (or glycolate), TBP, and cyanide is important with respect to the chemical state of technetium in the underground storage tanks at the Hanford Site and its release to the environment. An examination of the aqueous speciation and solubility of the radionuclides included in our review relative to the chemistry of liquid and solid wastes in the Hanford underground storage tanks was not part of the project scope. However, a search of the stability constant database by Smith et al. (1997) was done to determine if data existed to calculate the thermodynamic distribution of technetium aqueous species containing any of these complexing ligands. The database by Smith et al. (1997) contains the Tc(VII) and $\mathrm{Tc}(\mathrm{IV})$ oxidation states, and does not list any stability constants for $\mathrm{Tc}(\mathrm{VII})$ and $\mathrm{Tc}(\mathrm{IV})$ aqueous complexes with EDTA, HEDTA, NTA, citrate, hydroacetic acid (or glycolate), TBP, or cyanide. It is important to keep in mind that the lack of thermodynamic data for such complexes in an extensive,

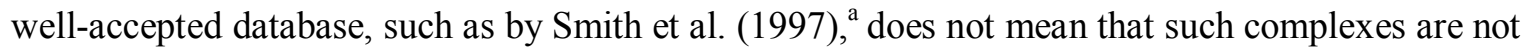
important. The lack of tabulated thermodynamic constants may simply indicate that the formation of such complexes has not been studied from the perspective of determining their thermodynamic constants and/or that data available for such complexes are suspect and require additional study and independent determination.

Rard et al. (1999) review the available published studies for the complexation of technetium with cyanides and oxycynanides. The formation of complexes, such as $\mathrm{Tc}^{\mathrm{VII}} \mathrm{O}(\mathrm{OH})_{2}(\mathrm{CN})_{4}{ }^{-}, \mathrm{Tc}^{\mathrm{V}} \mathrm{O}(\mathrm{CN})_{5}{ }^{2-}$, $\mathrm{Tc}^{\mathrm{V}} \mathrm{O}_{2}(\mathrm{CN})_{4}{ }^{3-}, \mathrm{Tc}^{\mathrm{VI}} \mathrm{NCl}_{3}(\mathrm{CN})^{-}$, have been suggested by these studies, but thermodynamic data are not available for such compounds (Rard et al. 1999).

Hughes and Rossotti (1987) review the literature pertaining to the solution chemistry of technetium as it relates to the reprocessing of nuclear fuels. The results of their review indicate that technetium forms

a The NIST distributes the computerized database of critically-selected stability constants by Smith et al. (1997). This is version 4.0 of this database, and version 6.0 is currently available from NIST. The computerized database by Smith et al. (1997) supercedes the printed tabulations of stability constants published by these authors, such as Smith and Martell (1976) for stability constants for inorganic complexes. 
PNNL-14126

stable complexes with aminopolycarboxylates, of which EDTA is the most common. Gorski and Koch (1970) used an ion exchange method to study the complexation of technetium with aminopolycarboxylates. They determined a stability constant $(\log \mathrm{K})$ of 19.1 for the formation of $\left[\mathrm{Tc}^{\mathrm{IV}} \mathrm{OOH}(\mathrm{EDTA})\right]^{3-\mathrm{a}}$. Later studies by Russell et al. (1980) $)^{\mathrm{a}}$ indicated that the net charge for this EDTA complex was -2 , and the complex might be $\left[\mathrm{Tc}^{\mathrm{III}} \mathrm{OH}(\mathrm{EDTA})\right]^{2-},\left[\mathrm{Tc}^{\mathrm{IV}} \mathrm{O}(\mathrm{EDTA})\right]^{2-}$, or $\left[\mathrm{Tc}^{\mathrm{V}} \mathrm{O}(\mathrm{OH})(\text { EDTA })\right]^{2-}$. Based on the relative stabilities of the technetium oxidation states, Russell et al. (1980) proposed that the complex was most likely a Tc(III)-EDTA complex. Gorski and Koch (1970) also determined stability constants for the formation of Tc(IV)-NTA complexes. These constants included $\log \mathrm{K}_{1}$ of 13.8 for [ $\left.\mathrm{Tc}^{\mathrm{IV}} \mathrm{OOH}(\mathrm{NTA})\right]^{2-}$ and $\log \mathrm{K}_{1} \mathrm{~K}_{2}$ of 28.7 for $\left[\mathrm{Tc}^{\mathrm{IV}} \mathrm{OOH}(\mathrm{NTA})_{2}\right]^{5-}$, where $\mathrm{K}_{1}$ and $\mathrm{K}_{2}$ are the stepwise formation constants for the complexation of $\mathrm{TcOOH}^{+}$with $\mathrm{NTA}^{3-\mathrm{a}}$. Hughes and Rossotti (1987) noted that the validity of these constants has been doubted by Noll et al. (1980) ${ }^{\mathrm{a}}$ based on the irreversibility of the systems.

\subsection{Solubility Limits}

Technetium(VII), $\mathrm{TcO}_{4}^{-}$, is highly soluble, and does not form solubility-controlling phases in soil systems. As discussed in Section 5.1, Tc(VII) can be reduced to Tc(IV) by biotic and abiotic processes. This reduction results in a decrease in the dissolved concentrations of technetium in the geochemical environment via the precipitation of the sparingly soluble solid $\mathrm{TcO}_{2} \cdot \mathrm{nH}_{2} \mathrm{O}$.

Numerous investigations have been conducted of the properties and hydration number of solid $\mathrm{TcO}_{2} \cdot \mathrm{nH}_{2} \mathrm{O}$ [see review of studies in Rard et al. (1999)]. Characterization data for this solid is limited, and a range of compositions, such as $\mathrm{TcO}_{2}(\mathrm{cr}), \mathrm{TcO}_{2} \cdot \mathrm{nH}_{2} \mathrm{O}, \mathrm{TcO}(\mathrm{OH})_{2}$, and $\mathrm{Tc}(\mathrm{OH})_{4}$, have been proposed by various investigators. This solid is considered to be essentially amorphous (Rard et al. 1999). However, this author (KMK) knows of no studies that have compared the X-ray diffraction characteristics of $\mathrm{TcO}_{2} \cdot \mathrm{nH}_{2} \mathrm{O}$ samples formed by different abiotic and biotic processes. Meyer et al. (1991) studied the solubility of $\mathrm{TcO}_{2} \cdot \mathrm{nH}_{2} \mathrm{O}$ in the $\mathrm{pH}$ range from 1 to 10 . The hydration numbers determined by Meyer et al. (1991) for their technetium solids ranged from 0.44 to 4.22 and from 1.38 to 1.81 for solids precipitated from acid and basic solution, respectively. For the formula used for $\mathrm{TcO}_{2} \cdot \mathrm{nH}_{2} \mathrm{O}$, Rard et al. (1999) selected 1.6, which corresponds to the value suggested by Meyer et al. (1991). However, as Rard et al (1999) notes, the exact value for the hydration number has no consequence on the solution chemistry and predicted environmental mobility of dissolved technetium.

Figure 5.2 shows the predicted stability range (i.e., region of oversaturation) for $\mathrm{TcO}_{2} \cdot 1.6 \mathrm{H}_{2} \mathrm{O}(\mathrm{am})$ as a function of Eh and $\mathrm{pH}$ calculated at $25^{\circ} \mathrm{C}$ and concentrations of $1 \times 10^{-7} \mathrm{mg} / \mathrm{L}$ total dissolved technetium in the absence of dissolved carbonate. Concentrations less than about $1 \times 10^{-7} \mathrm{mg} / \mathrm{L}$ total dissolved technetium are less than the predicted solubility of $\mathrm{TcO}_{2} \cdot 1.6 \mathrm{H}_{2} \mathrm{O}(\mathrm{am})$.

a Information cited from Gorski and Koch (1970), Noll et al. (1980), and Russell et al. (1980) taken as given from Hughes and Rossotti (1987). Copies of original references were not available for this review. 
PNNL-14126

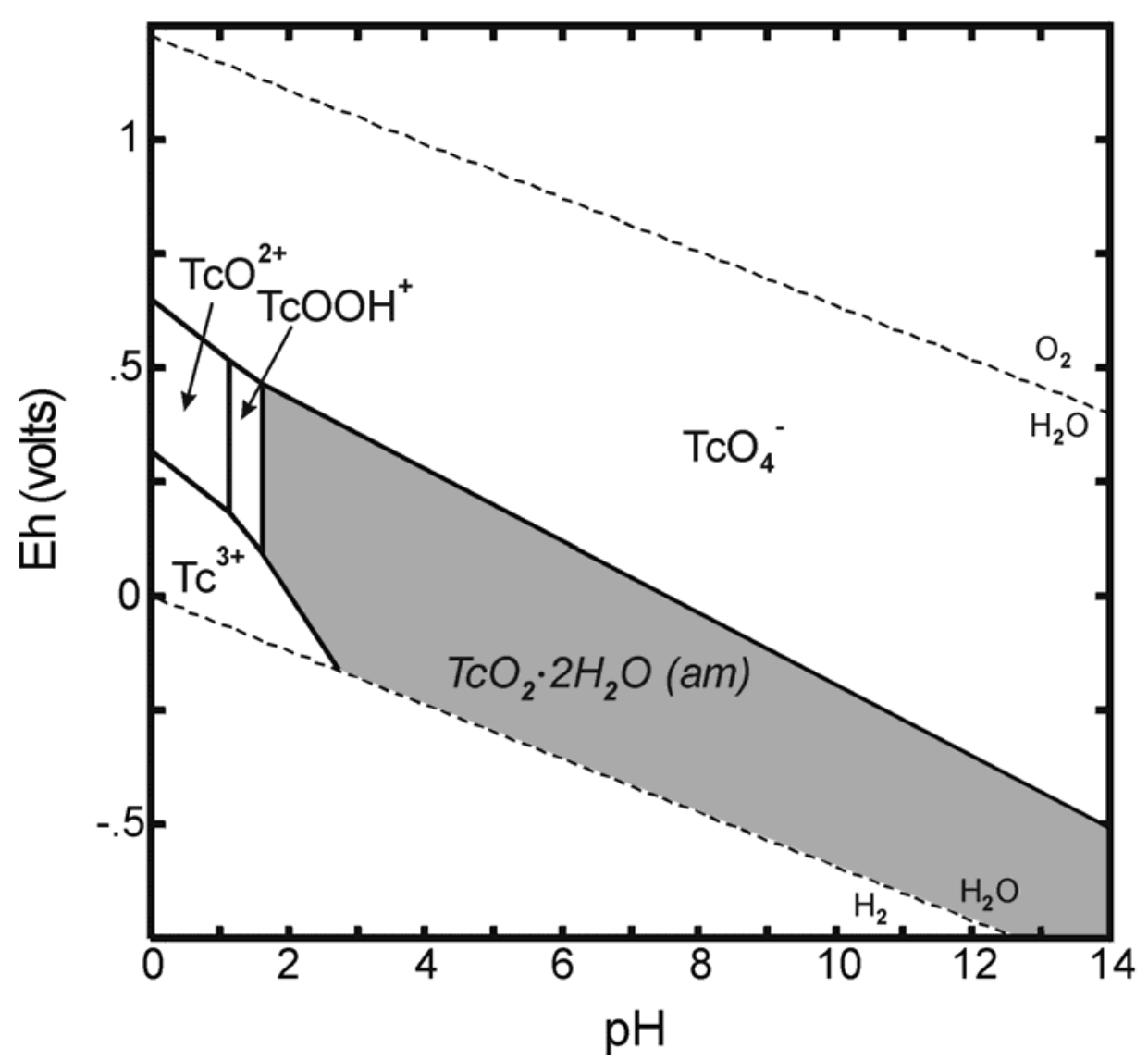

Figure 5.2. Eh-pH Diagram Showing Dominant Aqueous Species of Technetium and Eh-pH Regions (Shaded Areas) Where the Solubility of Solid Amorphous $\mathrm{TcO}_{2} \cdot 1.6 \mathrm{H}_{2} \mathrm{O}$ Has Been Exceeded [Diagram calculated at $25^{\circ} \mathrm{C}$ and a concentrations of $1 \times 10^{-7} \mathrm{mg} / \mathrm{L}$ total dissolved technetium in the absence of dissolved carbonate.]

In reduced iron-sulfide systems, Wharton et al. (2000) have shown that $\mathrm{Tc}$ (VII) can be reduced to $\mathrm{Tc}(\mathrm{IV})$ with coprecipitation with FeS solid (mackinawite). Due to the poorly ordered structures of the precipitates, they were not able to confirm if Tc(IV) was incorporated in the structure of the FeS solid or precipitated as a distinct technetium solid phase. Their X-ray absorption spectroscopy (XAS) results suggest that the reduction of technetium at these conditions may have precipitated a $\mathrm{TcS}_{2}$-like phase (Wharton et al. 2000).

\subsection{Adsorption}

Numerous studies of the sorption of technetium on sediments, soils, pure minerals, oxide phases, and crushed rock materials have been conducted. An extensive review of these studies is presented in EPA (2003). These studies consist of measurements of partition coefficient, $\mathrm{K}_{\mathrm{d}}$, values primarily for $\mathrm{Tc}(\mathrm{VII})$. No surface complexation (mechanistic) studies of the adsorption of technetium were identified during the completion of this review. 
The dominant technetium aqueous species under oxidizing conditions is the $\mathrm{Tc}(\mathrm{VII})$ oxyanion $\mathrm{TcO}_{4}{ }^{-}$ (Figures 5.1 and 5.2), which is highly soluble and essentially nonadsorptive. The adsorption of an anion, such as $\mathrm{TcO}_{4}{ }^{-}$, is expected to very low to zero at circumneutral and basic $\mathrm{pH}$ conditions, and to increase with decreasing $\mathrm{pH}$ at $\mathrm{pH}$ values less than 5 (EPA 1999, 2003). Technetium(IV) is considered to be essentially immobile, because it readily precipitates as sparingly soluble hydrous oxides and forms strong complexes with surface sites on iron and aluminum oxides and clays (EPA 2003).

\subsection{1 $K_{d}$ Studies for Technetium on Sediment Materials}

For soils with low contents of organic material, the reported $\mathrm{K}_{\mathrm{d}}$ values for $\mathrm{Tc}(\mathrm{VII})$ range from 0 to approximately $0.5 \mathrm{ml} / \mathrm{g}$, although most values are less than $0.1 \mathrm{ml} / \mathrm{g}$ (EPA 2003). The sorption of Tc(VII) has been found to be positively correlated to the organic carbon content of soils (Wildung et al. 1974). However, studies of the effect that organic material has on the sorption of Tc(VII) in soils are limited. As an extreme example, Sheppard and Thibault (1988) reported $\mathrm{K}_{\mathrm{d}}$ values of greater than $2 \mathrm{ml} / \mathrm{g}$ based on in situ $K_{d}$ values derived from analyses of the dried peat and pore water from the Precambrian Shield in Canada. Measurable adsorption of Tc(VII) observed in experiments conducted with organic material as well as with crushed rock and minerals containing reduced chemical components, such as Fe(II) and sulfide, has been attributed to the reduction of Tc(VII) to Tc(IV) and subsequent precipitation of Tc(IV) discrete and/or coprecipitated solid phases, as opposed to surface adsorption processes.

Cantrell et al. (2002) compiled the $\mathrm{K}_{\mathrm{d}}$ values measured with Hanford sediments for radionuclides and other toxic constituents of environmental impact to the vadose zone and groundwater at the Hanford Site. Based on their review, Cantrell et al. (2002) concluded that the adsorption of Tc(VII) is low for nearly all of the geochemical conditions associated with the vadose zone and upper unconfined aquifer at the Hanford Site. In the database complied by Cantrell et al. (2002), the technetium $\mathrm{K}_{d}$ values typically ranged from zero to $0.1 \mathrm{ml} / \mathrm{g}$, and were in a few studies as large as approximately $1 \mathrm{ml} / \mathrm{g}$. Cantrell et al. (2002) noted that high standard deviations were associated with the highest $\mathrm{K}_{\mathrm{d}}$ values reported for Hanford sediments.

The results of several technetium $\mathrm{K}_{\mathrm{d}}$ studies completed using Hanford sediments are briefly summarized below in this section. The $\mathrm{K}_{\mathrm{d}}$ values measured in these studies are tabulated in the original sources as well as EPA (2003) and Cantrell et al. (2002). Kaplan et al. (1998a) used the batch equilibration technique to measure the $\mathrm{K}_{\mathrm{d}}$ values for technetium under oxic conditions on twenty sediment samples from the Hanford formation at the Hanford Site. The sediment samples were taken from one borehole, and contained material from three layers of the Hanford formation. Each sediment sample was equilibrated with uncontaminated groundwater from the Hanford Site, which was spiked with ${ }^{99}$ Tc prior to the $\mathrm{K}_{\mathrm{d}}$ measurements. The groundwater solution had a low ionic strength and a $\mathrm{pH}$ of 8.4. The mean $K_{d}$ values of three replicates measured for technetium on each sediment sample ranged from -0.04 to $0.01 \mathrm{ml} / \mathrm{g}$. The negative $\mathrm{K}_{\mathrm{d}}$ values for technetium have usually been attributed to experimental error associated with measuring the concentration of a nonadsorbing solute, but Kaplan and Serne (1998) suggested that the negative $\mathrm{K}_{\mathrm{d}}$ values were due to anion exclusion effects.

Kaplan et al. (1998b) studied the effects of ionic strength and high $\mathrm{pH}$ on the sorption of technetium under oxic conditions on Hanford Site sediments. Batch sorption experiments were completed using the less than 2-mm size fraction of sediment collected from Trench AE-3 in the 200 Area of the Hanford Site. 
The sediment was characterized as a silty loam with cation exchange capacity (CEC) of $6.4 \mathrm{meq} / 100 \mathrm{~g}$. The carbonate content of the sediment is primarily calcite. Based on analyses reported by Kaplan et al. (1996) for a sediment from a nearby location, the Trench AE-3 sample was expected to contain approximately 0.2-0.5 wt.\% amorphous $\mathrm{Fe}_{2} \mathrm{O}_{3}$ (Kaplan et al. (1998b). The less than 2-mm size fraction contained $41 \%$ sand, $50 \%$ silt, and $9 \%$ clay. The clay fraction of the sediment contained primarily smectite (57\%), illite (19\%), and vermiculite (14\%). The groundwater selected for the sorption studies was an uncontaminated groundwater from the Hanford Site with a low ionic strength and $\mathrm{pH}$ of 8.4 [see Table 2.2 in Kaplan et al. (1998b)]. The effect of ionic strength on the sorption of technetium was investigated by adding $0.05,0.10,0.50$, and $1.00 \mathrm{M} \mathrm{NaClO}_{4}$ solutions to the groundwater. To study the effect of high $\mathrm{pH}$ on the sorption of technetium, $\mathrm{NaOH}$ was added to separate samples of groundwater to adjust the $\mathrm{pH}$ to $8.1,9.9,10.2,11.0$, and 11.9. The sediment was equilibrated with these amended groundwater solutions. Based on the experimental conditions and geochemical modeling calculations, the dissolved technetium was assumed to be present as the $\mathrm{Tc}(\mathrm{VII})$ anion $\mathrm{TcO}_{4}{ }_{4}^{-}$. The mean $\mathrm{K}_{\mathrm{d}}$ values of three replicates measured for technetium in the ionic strength and $\mathrm{pH}$ experiments are listed in Table 5.1. The reason for the high $\mathrm{K}_{\mathrm{d}}$ value $(3.94 \mathrm{ml} / \mathrm{g})$ measured for technetium in the $1.00 \mathrm{M} \mathrm{NaClO}_{4}$ solution was not known. Kaplan et al. (1998b) speculated that the higher ionic strength allowed greater interaction of the technetium with the mineral surfaces by decreasing the double layer around the sediment particles. The $\mathrm{K}_{\mathrm{d}}$ values determined for technetium (i.e., 1.04 to $1.07 \mathrm{ml} / \mathrm{g}$ ) at $\mathrm{pH}$ values greater than 8.8 in the $\mathrm{NaOH}$-amended solutions were greater than expected. The reason for these greater-than-expected values was not known.

Table 5.1. Technetium $\mathrm{K}_{\mathrm{d}}$ Values ( $\mathrm{ml} / \mathrm{g}$ ) Measured by Kaplan et al. (1998b) for Hanford Trench AE-3 Sediment (CEC = $6.4 \mathrm{meg} / 100 \mathrm{~g})$ Under Oxidizing Conditions.

\begin{tabular}{|c|c|l|}
\hline $\mathbf{p H}$ & $\left.\mathbf{K}_{\mathbf{d}} \mathbf{( m l} / \mathbf{g}\right)$ & \multicolumn{1}{c|}{ Solution } \\
\hline \hline 7.74 & $-0.16 \pm 0.04$ & Groundwater $+0.05 \mathrm{M} \mathrm{NaClO}_{4}$ \\
\hline 7.76 & $-0.13 \pm 0.00$ & Groundwater $+0.1 \mathrm{M} \mathrm{NaClO}_{4}$ \\
\hline 7.73 & $-0.28 \pm 0.01$ & Groundwater $+0.5 \mathrm{M} \mathrm{NaClO}_{4}$ \\
\hline 7.70 & $3.95 \pm 0.99$ & Groundwater $+1.0 \mathrm{M} \mathrm{NaClO}$ \\
\hline 8.1 & $-0.02 \pm 0.01$ & Groundwater $+\mathrm{NaOH}$ \\
\hline 9.9 & $1.04 \pm 0.06$ & Groundwater $+\mathrm{NaOH}$ \\
\hline 10.2 & $1.05 \pm 0.02$ & Groundwater $+\mathrm{NaOH}$ \\
\hline 11.0 & $1.07 \pm 0.05$ & Groundwater $+\mathrm{NaOH}$ \\
\hline 11.9 & $1.07 \pm 0.03$ & Groundwater $+\mathrm{NaOH}$ \\
\hline \hline
\end{tabular}

Kaplan and Serne (1998) [also see Kaplan et al. (1996)] used the batch technique to measure the $\mathrm{K}_{\mathrm{d}}$ values for technetium, as $\mathrm{TcO}_{4}^{-}$, on a loamy sand (sample TSB-1), a silty loam (sample Trench AE-3), and a very coarse sand (sample Trench-94) from the Hanford Site. The measurements were conducted with a groundwater sample $(\mathrm{pH} \mathrm{8.3)} \mathrm{taken} \mathrm{from} \mathrm{a} \mathrm{well} \mathrm{located} \mathrm{in} \mathrm{an} \mathrm{uncontaminated} \mathrm{area} \mathrm{of} \mathrm{the} \mathrm{Hanford}$ Site. The $\mathrm{K}_{\mathrm{d}}$ values at 266 days of contact time were very low for all sediments, and ranged from 0.11 to $-0.18 \mathrm{mg} / 1$. 
Kaplan et al. (1996) measured the $\mathrm{K}_{\mathrm{d}}$ values for $\mathrm{TcO}_{4}{ }^{-}$on sediment samples from the 200 Areas at the Hanford Site. The sorption measurements were conducted under oxidizing conditions using uncontaminated groundwater ( $\mathrm{pH} \mathrm{8.46)}$ from Hanford Site well 699-S3-25. The sorption values for $\mathrm{TcO}_{4}{ }^{-}$ were determined for three sediment samples, Trench 94, Trench AE-3, and TSB-1, using the batch equilibration method. No significant sorption of $\mathrm{TcO}_{4}{ }^{-}$was observed. The average $\mathrm{K}_{\mathrm{d}}$ values measured after 30 days of contact for Trench 94 and Trench AE-3 sediments were $-0.02 \mathrm{ml} / \mathrm{g}$ and $-0.05 \mathrm{ml} / \mathrm{g}$, respectively. The effect of contact time ( 7 to 398 days) on the sorption of $\mathrm{TcO}_{4}{ }^{-}$to these sediments was also studied by Kaplan et al. (1996). The $K_{d}$ values for all three sediments varied from slightly negative at short contact times to slightly positive at contact times greater than 300 days. The values ranged from -0.18 to $0.11 \mathrm{ml} / \mathrm{g}$.

Serne et al. (1993) used the batch-equilibration method under oxidizing conditions to measure the $\mathrm{K}_{\mathrm{d}}$ values for Tc(VII) on two loamy sands (samples TBS-1 and Trench-8) and one sand (sample CGS-1) from the Hanford formation. The measurements were conducted using an uncontaminated groundwater ( $\mathrm{pH}$ 8.14) sample from the Hanford Site. Characterization of the sediment samples indicated that they contained very little amorphous or poorly crystalline hydrous aluminum, manganese, and iron oxides (determined by hydroxylamine-hydrochloride extraction) and very low organic carbon contents. After 35 days of contact, the $\mathrm{pH}$ values for the CGS-1, TBS-1, and Trench-8 sediment suspensions were 7.9-8.4, 8.0-8.4, and 8.22, respectively. No significant sorption of technetium was measured. The $\mathrm{K}_{\mathrm{d}}$ values for Tc(VII) were $0.1 \mathrm{ml} / \mathrm{g}$ for CGS-1 sediment at 35 days, $0.1 \mathrm{ml} / \mathrm{g}$ for TBS- 1 sediment at 35 days, and $0.2 \mathrm{ml} / \mathrm{g}$ for Trench- 8 sediment at 44 days.

Gee and Campbell (1980) conducted batch equilibration and unsaturated flow column studies of the sorption behavior of technetium using two Hanford Site sediments and a series of synthetic groundwater solutions. The sediments include a sample from the Ringold Formation (deep, old sediment) and a surface soil sample at the Hanford Site. Except for the degree of crystallinity of the clay minerals, the two sediments were similar with respect to their clay mineralogy. The compositions of the synthetic groundwater solutions were developed to simulate the composition of a solution as it changes in response to its initial contact and saturation of arid sediment and its progressive percolation through the arid sediment. Gee and Campbell (1980) found low sorption of technetium, and no relationship in the technetium $\mathrm{K}_{\mathrm{d}}$ values with respect to soil type, solution composition, $\mathrm{pH}$, and contact time. The technetium $\mathrm{K}_{\mathrm{d}}$ values for the two sediment samples ranged from -2.34 to $1.27 \mathrm{ml} / \mathrm{g}$ at 8.5 days, and -2.77 to $0.57 \mathrm{ml} / \mathrm{g}$ at 21.5 days.

\subsection{2 $K_{d}$ Studies for Technetium on Other Geologic Sediment Materials}

Numerous technetium adsorption studies have been conducted of technetium on pure mineral, oxide phases, and crushed rock materials. The reader is referred to the studies tabulated in EPA (2003). Many of the pure mineral and oxide studies were completed due to extensive research interest in developing getters (adsorbents) that could be added to waste streams and tailored barriers for removal and/or immobilization of dissolved iodine [e.g., see Zhang et al. (2000); Balsley et al. (1997); Gu and Dowlen (1997); and others]. High sorption of technetium is typically observed for minerals, such as sulfide minerals (e.g., chalcopyrite, pyrite), that have the capacity to reduce $\mathrm{Tc}(\mathrm{VII})$ to $\mathrm{Tc}(\mathrm{IV})$. For example, Strickert et al. (1980) measured $\mathrm{K}_{\mathrm{d}}$ values in the range 100 to $2,000 \mathrm{ml} / \mathrm{g}$ for sorption of technetium on sulfide minerals such as bournonite, chalcopyrite, pyrite, tennantite, and tetrahedrite. Technetium $\mathrm{K}_{\mathrm{d}}$ 
values were however less than $1 \mathrm{ml} / \mathrm{g}$ for non-sulfide materials, such as anhydrite, basalt, granite, and tuff. The studies of technetium sorption on crushed rock were conducted typically as part of national research programs to investigate the feasibility of geological disposal of high-level radioactive waste (HLW). As noted previously, large $\mathrm{K}_{\mathrm{d}}$ values measured for $\mathrm{Tc}(\mathrm{VII})$ in experiments conducted under oxic conditions and with geologic materials containing reduced chemical components, such as Fe(II) and sulfide, are likely the result of the reduction of $\mathrm{Tc}(\mathrm{VII})$ to $\mathrm{Tc}(\mathrm{IV})$ and subsequent precipitation of $\mathrm{Tc}(\mathrm{IV})$ discrete and/or coprecipitated solid phases.

\subsection{References}

Ames LL and D Rai. 1978. Radionuclide Interactions with Soil and Rock Media. Volume 1: Processes Influencing Radionuclide Mobility and Retention, Element Chemistry and Geochemistry, and Conclusions and Evaluations. EPA 520/6-78-007-a, U.S. Environmental Protection Agency, Las Vegas, Nevada.

Balsley SD, PV Brady, JL Krumhans1, and HL Anderson. 1997. ${ }^{129} \mathrm{I}_{\text {and }}{ }^{99} \mathrm{TcO}_{4}^{-}$Scavengers for Low Level Radioactive Waste Backfills. SAND95-2978, Sandia National Laboratories, Albuquerque, New Mexico.

Beasley TM and HV Lorz. 1984. "A Review of the Biological and Geochemical Behavior of Technetium in the Marine Environment." In Technetium in the Environment, G Desment and C Myttenaere, pp. 197-2xx, Elsevier, New York, New York.

Blanchard DL, Jr, GN Brown, SD Conradson, SK Fadeff, GR Golcar, NJ Hess, GS Klinger, and DE Kurath. 1997. Technetium in Alkaline, High Salt, Radioactive Tank Waste Supernate: Preliminary Characterization and Removal. PNNL-11386, Pacific Northwest Laboratory, Richland, Washington.

Cantrell KJ, RJ Serne, and GV Last. 2002. Hanford Contaminant Distribution Coefficient Database and Users Guide. PNNL-13895, Pacific Northwest National Laboratory, Richland, Washington.

Coughtrey PJ, D Jackson, and MC Thorne. 1983. Radionuclide Distribution and Transport in Terrestrial and Aquatic Ecosystems. A Critical Review of Data. AA Balkema, Rotterdam, Netherlands.

Dilworth JR and SJ Parrot. 1998. "The Biomedical Chemistry of Technetium and Rhenium.” Chemical Society Reviews, 27:43-55.

EPA(U.S. Environmental Protection Agency). 1999. Understanding Variation in Partition Coefficient, $K_{d}$, Values: Volume I. The $K_{d}$ Model, Methods of Measurement, and Application of Chemical Reaction Codes. EPA 402-R-99-04A, prepared for the U.S. Environmental Protection Agency, Washington, D.C. by Pacific Northwest National Laboratory, Richland, Washington.

EPA (U.S. Environmental Protection Agency). 2003 (in press). Understanding Variation in Partition Coefficient, Kd, Values: Volume III. Review of Geochemistry and Available $K_{d}$ Values for Americium, Arsenic, Curium, Iodine, Neptunium, Radium, and Technetium. EPA 402-R-99-004C, U.S. Environmental Protection Agency, Washington, D.C. prepared by KM Krupka and RJ Serne at the Pacific Northwest National Laboratory, Richland, Washington. 
Eriksen TE, P Ndalamba, J Bruno, and M Caceci. 1992. "The Solubility of $\mathrm{TcO}_{2} \mathrm{AnH}_{2} \mathrm{O}$ in Neutral to Alkaline Solutions under Constant $\mathrm{p}_{\mathrm{CO} 2}$." Radiochimica Acta, 58/59:67-70.

Fredrickson JK, HM Kostandarithes, SW Li, AE Plymale, and MJ Daly. 2000. "Reduction of Fe(III), $\mathrm{Cr}(\mathrm{VI}), \mathrm{U}(\mathrm{VI})$, and Tc(VII) by Deinococcus radiodurans R1.” Applied and Environmental Microbiology, 66:2006-2011.

Gorski B and H Koch. 1970. "Uber die Komplexbideling von Technetium mit Chelatbildenden Ligande - II." Journal of Inorganic and Nuclear Chemistry, 32:3831-3836.

Gee GW and AC Campbell. 1980. Monitoring and Physical Characterization of Unsaturated Zone Transport - Laboratory Analysis. PNL-3304, Pacific Northwest Laboratory, Richland, Washington.

Gu B and KE Dowlen. 1996. An Investigation of Groundwater Organics, Soil Minerals, and Activated Carbon on the Complexation, Adsorption, and Separation of Technetium-99. ORNL/TM-13154, Oak Ridge National Laboratory, Oak Ridge, Tennessee.

Gu B and RK Schulz. 1991. Anion Retention in Soil: Possible Application to Reduce Migration of Buried Technetium and Iodine. NUREG/CR-5464, prepared by the University of California at Berkeley, California for the U. S. Nuclear Regulatory Commission, Washington, D.C.

Hughes MA and FJC Rossotti. 1987. A Review of Some Aspects of the Solution Chemistry of Technetium. AERE-R 12820, University of Oxford, Oxford, England.

Jones AG. 1995. “Technetium in Nuclear Medicine.” Radiochimica Acta, 70/71:289-297.

Kaplan DI and RJ Serne. 1998. "Pertechnetate Exclusion from Sediments.” Radiochimica Acta, 81:117-124.

Kaplan DI, RJ Serne, AT Owen, J Conca, TW Wietsma, and TL Gervais. 1996. Radionuclide Adsorption Distribution Coefficients Measured in Hanford Sediments for the Low Level Waste Performance Assessment Project. PNNL-11485, Pacific Northwest Laboratory, Richland, Washington.

Kaplan DI, KE Parker, and IV Kutynakov. 1998a. Radionuclide Distribution Coefficients for Sediments Collected form Borehole 299-E17-21: Final Report for Subtask-1a. PNNL-11966, Pacific Northwest National Laboratory, Richland, Washington.

Kaplan DI, KE Parker, and RD Orr. 1998b. Effects of High-pH and High-Ionic-Strength Groundwater on Iodide, Pertechnetate, and Selenate Sorption to Hanford Sediments: Final Report for Subtask $3 a$. PNNL-11964, Pacific Northwest National Laboratory, Richland, Washington.

Lieser KH. 1993. "Technetium in the Nuclear Fuel Cycle, in Medicine and in the Environment." Radiochimica Acta, 63:5-8.

Lloyd JR and LE Macaskie. 1996. "A Novel PhoshorImager-Based Technique for Monitoring the Microbial Reduction of Technetium." Applied and Environmental Microbiology, 62(2):578-582. 
PNNL-14126

Lloyd JR, JA Cole, and LE Macaskie. 1997. "Reduction and Removal of Heptavalent Technetium from Solution by Escherichia coli." Journal of Bacteriology, 179(6):2014-2021.

Lloyd JR, HF Nolting, VA Solé, K Bosecker, and LE Macaskie. 1998. "Technetium Reduction and Precipitation by Sulfate-Reducing Bacteria.” Geomicrobiology Journal, 15:45-58.

Lloyd JR, J Ridley, T Khizniak, NN Lyalikova, and LE Macaskie. 1999. "Reduction of Technetium by Desulfovibrio desulfuricans: Biocatalyst Characterization and Use in a Flowthrough Bioreactor." Applied and Environmental Microbiology, 65, 2691-2696.

Lloyd JR, VA Sole, CVG Van Praagh, and DR Lovley. 2000. "Direct and Fe(II)-Mediated Reduction of Technetium by Fe(III)-Reducing Bacteria.” Applied and Environmental Microbiology, 66:3743-3749.

Lovley DR. 1993. “Dissimilatory Metal Reduction.” Annual Review of Microbiology, 47:263-290.

Lovley DR. 1995. "Bioremediation of Organic and Metal Contaminants with Dissimilatory Metal Reduction." Journal of Industrial Microbiology, 14:85-93.

Mazzi U. 1989. "The Coordination Chemistry of Technetium in its Intermediate Oxidation States." Polyhedron, 8:1683-1688.

Meyer RE, WD Arnold, and FI Case. 1985. Valence Effects on the Adsorption of Nuclides on Rocks and Minerals II. NUREG/CR-4114, prepared for the U.S. Nuclear Regulatory Commission by Oak Ridge National Laboratory, Oak Ridge, Tennessee.

Meyer RE, WD Arnold, FI Case, and GD O'Kelley. 1991. "Solubilities of Tc(IV) Oxides." Radiochimica Acta 55:11-18.

Noll B, S Seifert, and R Münze. 1980. "New Tc(IV) Compounds with Nitriloacetic Acid." Radiochemical and Radioanalytical Letters, 43:215-218.

Onishi Y, RJ Serne, EM Arnold, CE Cowan, and FL Thompson. 1981. Critical Review: Radionuclide Transport, Sediment Transport, and Water Quality Mathematical Modeling; and Radionuclide Adsorption/Desorption Mechanisms. NUREG/CR-1322 (PNL-2901), prepared for the U.S. Nuclear Regulatory Commission, Washington, D.C. by Pacific Northwest Laboratory, Richland, Washington.

Paquette J and WE Lawrence. 1985. "A Spectroelectrochemical Study of the Technetium(IV)/ Technetium(III) Couple in Bicarbonate Solutions.” Canadian Journal of Chemistry, 63:2369-2373.

Rard JA, MH Rand, G Anderegg, and H Wanner (MCA Sandino and E Östhols, eds.). 1999. Chemical Thermodynamics 3: Chemical Thermodynamics of Technetium. North-Holland, Elsevier Science Publishing Company, Inc., New York, New York. 
Russell CD, RC Crittenden, and AG Cash. 1980. "Determination of Net Ionic Charge on Tc-99m DTPA and Tc-99m EDTA by a Column Ion-Exchange Method.” Journal of Nuclear Medicine, 21:354-360.

Serne RJ, JL Conca, VL LeGore, KJ Cantrell, CW Lindenmeier, JA Campbell, JE Amonette, and MI Wood. 1993. Solid Waste Leach Characteristics and Contaminant-Sediment Interactions. Volume 1: Batch Leach and Adsorption Tests and Sediment Characterization. PNL-8889, Volume 1, Pacific Northwest Laboratory, Richland, Washington.

Sheppard MI and DH Thibault. 1988. "Migration of Technetium, Iodine, Neptunium, and Uranium in the Peat of Two Minerotrophic Mires.” Journal of Environmental Quality, 17:644-653.

Smith RM and AE Martell. 1976. Critical Stability Constants. Volume 4: Inorganic Complexes. Plenum Press, New York, New York.

Smith RM, AE Martell, and RJ Motekaitis. 1997. NIST Critically Selected Stability Constants of Metal Complexes Database. Version 4.0. User's Guide. NIST Standard Reference Database 46, National Institute of Standards and Technology, Gaithersburg, Maryland. (Includes software and database files for use on personal computers using DOS and Windows operating systems.)

Sparks ST and SE Long. 1987. The Chemical Speciation of Technetium in the Environment: A Literature Study. DOE/RW 88.098 (UKAEA/DOE Radiological Protection Research Programme Letter AERE-R 12743), Harwell Laboratory, Oxfordshire, England.

Strickert R, AM Friedman, and S Fried. 1980. "The Sorption of Technetium and Iodine Radioisotopes by Various Minerals.” Nuclear Technology, 49:253.

Wharton MJ, B Atkins, JM Charnock, FR Livens, RAD Pattrick, and D Collison. 2000. "An X-ray Absorption Spectroscopy Study of the Coprecipitation of Tc and Re with Mackinawite (FeS)." Applied Geochemistry, 15:347-354.

Wildung RE, RC Routson, RJ Serne, and TR Garland. 1974. "Pertechnetate, Iodide and Methyl Iodide Retention by Surface Soils." In Pacific Northwest Laboratory Annual Report for 1974 to the USAEC Division of Biomedical and Environmental Research. Part 2. Ecological Sciences, BE Vaughan (manager), pp. 37-40, BNWL-1950 PT2, Pacific Northwest Laboratories, Richland, Washington.

Wildung RE, KM McFadden, and TR Garland. 1979. "Technetium Sources and Behavior in the Environment." Journal of Environmental Quality, 8:156-161.

Wildung RE, YA Gorby, KM Krupka, NJ Hess, SW Li, AE Plymale, JP McKinley, and JK Fredrickson. 2000. "Effect of Electron Donor and Solution Chemistry on the Products of the Dissimilatory Reduction of Technetium by Shewanella putrefaciens." Applied and Environmental Microbiology, 66:2452-2460.

Zhang P-C, JL Krumhansl, and PV Brady. 2000. "Boehmite Sorbs Perrhenate and Pertechnetate.” Radiochimica Acta, 88:369-373. 
PNNL-14126

\subsection{Uranium}

Uranium (U) (atomic number 92) is a member of the actinide or actinoid series of elements in Group IIIB of the periodic classification of the elements. The uranium isotopes of primary interest to waste disposal and site remediation activities at the Hanford Site include ${ }^{235} U$ and ${ }^{238} U$. Both of these uranium isotopes are present in naturally occurring uranium. The half lives $\left(\mathrm{t}_{1 / 2}\right)$ of ${ }^{235} \mathrm{U}$ and ${ }^{238} \mathrm{U}$ are $7.04 \times 10^{8}$ and $4.47 \times 10^{9}$ years, respectively.

The geochemical behavior of uranium has received extensive study due to the importance of uranium as an energy source and a geochronology indicator. During the past 20 years, research in uranium geochemistry and mineralogy has concentrated on issues pertaining to the disposal of spent nuclear fuel and related nuclear wastes in subsurface geological repositories and to the remediation and safe disposal of uranium-contaminated wastes, soils, and ground water associated with uranium mines, mill tailing sites, and nuclear energy and weapons production facilities. Numerous studies have also been conducted of uranium ore deposits as possible natural analogues for the long-term performance of geological repositories for nuclear wastes. There have been several published reviews of the geochemical behavior of uranium. The review by Langmuir (1978) and an updated discussion in Langmuir (1997) are particularly noteworthy. In 1999, an extensive compilation of detailed reviews on the mineralogical, geochemical, and environmental behavior of uranium was published in Burns and Finch (1999). This compilation is especially valuable because of the detail and recentness of the included papers, the extensive list of references supporting each paper, and the wide range of topics covered by the reviews. Topics covered in this compilation of papers include the reviews of the mineralogy and paragenesis of uranium minerals; the genesis of uranium ore deposits; the geochemical behavior of uranium in natural fluids; environmental aspects of uranium geochemistry, such as microbial effects, groundwater contamination, and nuclear waste disposal; and analytical techniques for characterization of uraniumbearing phases (Burns and Finch 1999).

\subsection{Oxidation States}

Uranium can exist in the $+3,+4,+5$, and +6 , oxidation states in aqueous environments. Dissolved $\mathrm{U}(\mathrm{III})$ easily oxidizes to U(IV) under most reducing conditions found in nature. The U(V) aqueous species $\left(\mathrm{UO}_{2}{ }^{+}\right)$readily disproportionates to $\mathrm{U}(\mathrm{IV})$ and $\mathrm{U}(\mathrm{VI})$. Consequently, $\mathrm{U}(\mathrm{IV})$ and $\mathrm{U}(\mathrm{VI})$ (i.e., uranyl) are the most common oxidation states of uranium in natural environments. Uranium will exist in the +6 valence state under oxidizing to mildly reducing environments. The +4 valence state of uranium is stable under reducing conditions, and is considered relatively immobile. Under reducing conditions and $\mathrm{pH}$ conditions expected for natural waters, $\mathrm{U}(\mathrm{IV})$ forms sparingly soluble minerals, such as uraninite $\left(\mathrm{UO}_{2}\right)$.

As with the oxidation/reduction of technetium, the reduction of U(VI) to U(IV) by abiotic and biotic processes has recently received considerable attention, because the oxidation state of uranium has a significant affect on its mobility in waste streams and the natural environment. These reaction processes are the basis for certain remediation technologies, such as permeable barriers composed of zero-valent iron particles (i.e., as metallic iron) or sodium-dithionite reduced soils. Microbial reduction of U(VI) has 
also been suggested as a potential mechanism for removal of uranium from contaminated waters and soils [e.g., Lovley $(1993,1995)]$. Suzuki and Banfield (1999) provide a detailed review and extensive reference list on the interactions between uranium and microorganisms.

\subsection{Aqueous Speciation}

Grenthe et al. (1992), and revisions in Grenthe et al. (1995), have published an extensive, critical review of the thermodynamics of uranium. It is the most detailed review completed to date of the chemistry and available thermodynamic data for inorganic uranium compounds. Figure 6.1 is an Eh-pH diagram for the hydrolysis of uranium based on the thermodynamic data from Grenthe et al. $(1992,1995)$. The diagram was calculated for a total concentration of uranium of $10^{-7} \mathrm{~mol} / \mathrm{L}(24 \mu \mathrm{g} / \mathrm{L})^{\mathrm{a}}$ in the absence of dissolved complexing ligands other than hydroxide.

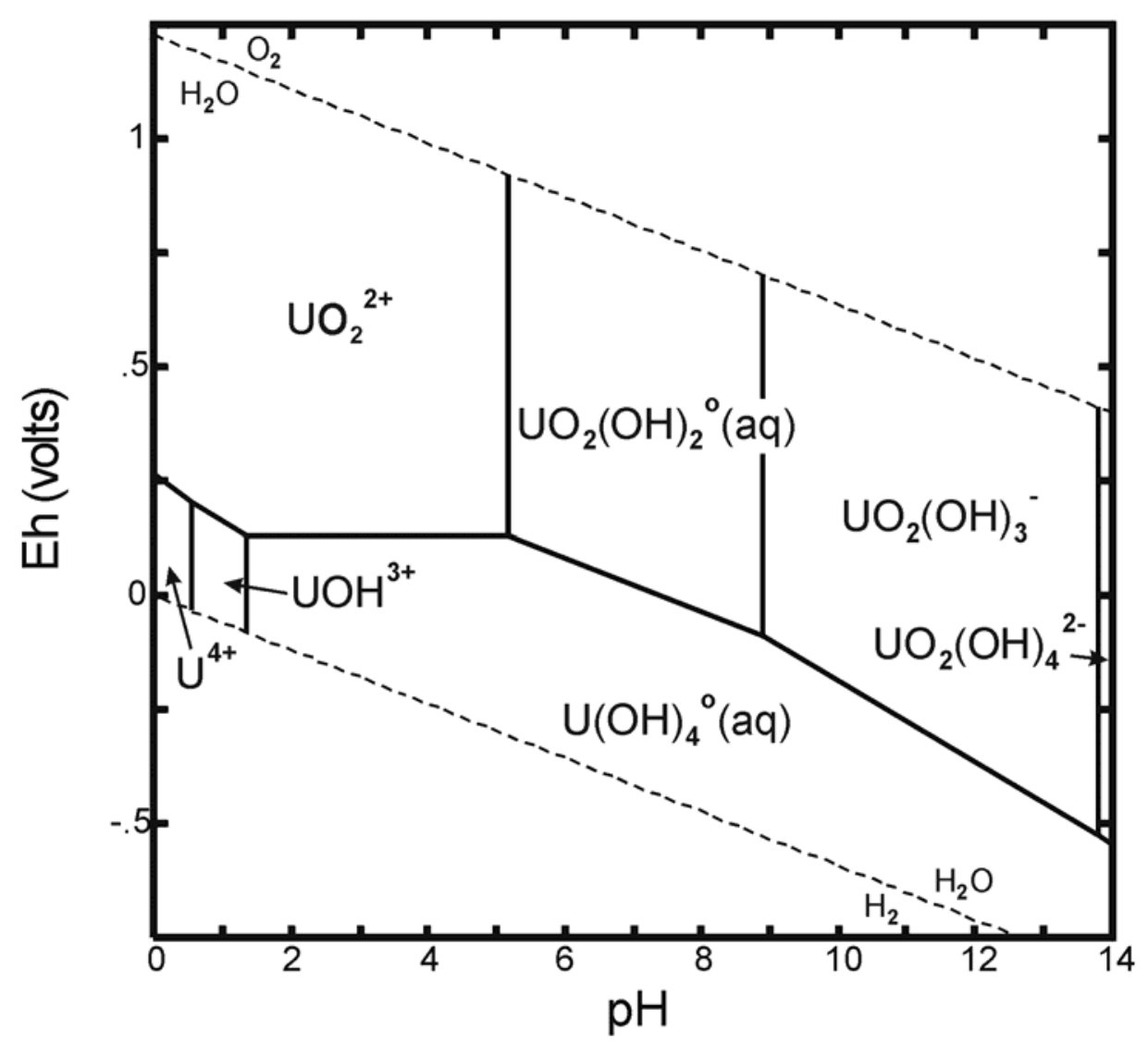

Figure 6.1. Eh-pH Diagram Showing the Hydrolysis of U(VI) and U(IV) in the Absence of Other Complexing Ligands [Diagram was calculated at $25^{\circ} \mathrm{C}$ and a concentration of $10^{-7} \mathrm{~mol} / \mathrm{L}$ total dissolved uranium.]

a The interim drinking water standard (DWS) for uranium is $20 \mu \mathrm{g} / \mathrm{L}$. 
The dominant uncomplexed and hydrolytic species of U(VI) and U(IV) are shown as a function of Eh and $\mathrm{pH}$ in Figure 6.1. Figure 6.1 clearly indicates that under oxidizing and mildly reducing conditions, $\mathrm{U}(\mathrm{VI})$ species dominate over the entire $\mathrm{pH}$ range. The hydrolysis of $\mathrm{U}(\mathrm{VI})$ does not become appreciable until $\mathrm{pH}$ values greater than 5. In the absence of other complexing ligands other than hydroxide, the dominant aqueous $\mathrm{U}(\mathrm{VI})$ species are $\mathrm{UO}_{2}{ }^{2+}$ at $\mathrm{pH}$ values less than $5, \mathrm{UO}_{2}(\mathrm{OH})_{2}{ }^{\mathrm{o}}(\mathrm{aq})$ at $\mathrm{pH}$ values between 5 and 9 , and $\mathrm{UO}_{2}(\mathrm{OH})_{3}{ }^{-}$at $\mathrm{pH}$ values between 9 and 14. At uranium concentrations greater than approximately $1,000 \mu \mathrm{g} / \mathrm{L}$ dissolved $\mathrm{U}(\mathrm{VI})$, polynuclear species, such as $\left(\mathrm{UO}_{2}\right)_{3}(\mathrm{OH})_{5}{ }^{+}$and $\left(\mathrm{UO}_{2}\right)_{2}(\mathrm{OH})_{2}{ }^{2+}$, begin to dominate the hydrolysis of $\mathrm{U}(\mathrm{VI})$ at $\mathrm{pH}$ values of 5 and greater with increasing concentrations of $\mathrm{U}(\mathrm{VI})$. Under reducing conditions, $\mathrm{U}(\mathrm{IV})$ is stable. At $\mathrm{pH}$ values greater than 2, the hydrolysis of $\mathrm{U}(\mathrm{IV})$ is dominated by the neutral species $\mathrm{U}(\mathrm{OH})_{4}{ }^{\circ}(\mathrm{aq})$ (Figure 6.1).

Figure 6.2 shows the Eh-pH diagram for the dominant uranium aqueous species calculated for total concentrations of dissolved uranium, chloride, nitrate, carbonate, and sulfate of $0.024\left(10^{-7} \mathrm{~mol} / \mathrm{L}\right), 22$, 1.7, 67.5, and $108 \mathrm{mg} / \mathrm{L}$, respectively. The concentrations selected for these ligands are based on a composition for uncontaminated groundwater from the Hanford Site listed by Kaplan et al. (1996). Figure 6.2 indicates that sulfate complexes would dominate the aqueous speciation of uranium at $\mathrm{pH}$ values less than 3. At higher $\mathrm{pH}$ values, the speciation of $\mathrm{U}(\mathrm{VI})$ is dominated by a series of strong aqueous carbonate complexes which increase the solubility of uranium at these environmental conditions (Langmuir 1997). Because anions do not readily adsorb to mineral surfaces at basic $\mathrm{pH}$ conditions (EPA 1999a), the anionic charge of the aqueous U(VI) carbonate complexes at $\mathrm{pH}$ values greater than 6 result in decreased adsorption and thus increased mobility of uranium (Section 6.4). The Hanford vadose zone and upper unconfined aquifer environments contain adequate carbonate concentrations to have these uranyl carbonate complexes dominate the aqueous speciation of uranium. In fact, direct verification for the uranyl carbonate dominance in vadose zone pore waters from borehole 299-E33-45 is presented in Appendix D in Field Investigation Report for Waste Management Area B-BX-BY. Volume 2 (Knepp 2002). Under reducing conditions, the speciation of $\mathrm{U}(\mathrm{IV})$ is dominated by $\mathrm{U}(\mathrm{OH})_{4}{ }^{\mathrm{o}}$ (aq) at $\mathrm{pH}$ values greater than 2 in the presence of the dissolved chloride, nitrate, carbonate, and sulfate (Figure 6.2).

\subsection{Solubility}

Approximately 220 mineral species that contain uranium as a necessary structural component are known. ${ }^{a}$ These include a diversity of simple and multiple oxides, carbonates, sulfates, molybdates, phosphates, arsenates, vanadates, and silicates that form under a variety of low and high temperature conditions. Finch and Murakami (1999) present a detailed review and extensive reference list on the structures [also see Smith (1984)] and formation conditions of uranium minerals. Given the omnipresence of carbonate in natural systems and the formation of aqueous U(VI) carbonate complexes (Section 6.2), adsorption instead of solubility will likely control the concentration of U(VI) under oxidizing conditions at dilute concentrations of dissolved uranium away from source terms of uranium contamination.

\footnotetext{
a Statement based on a search of Web-based mineralogical database at http://webmineral.com/chemical.shtml
} 
PNNL-14126

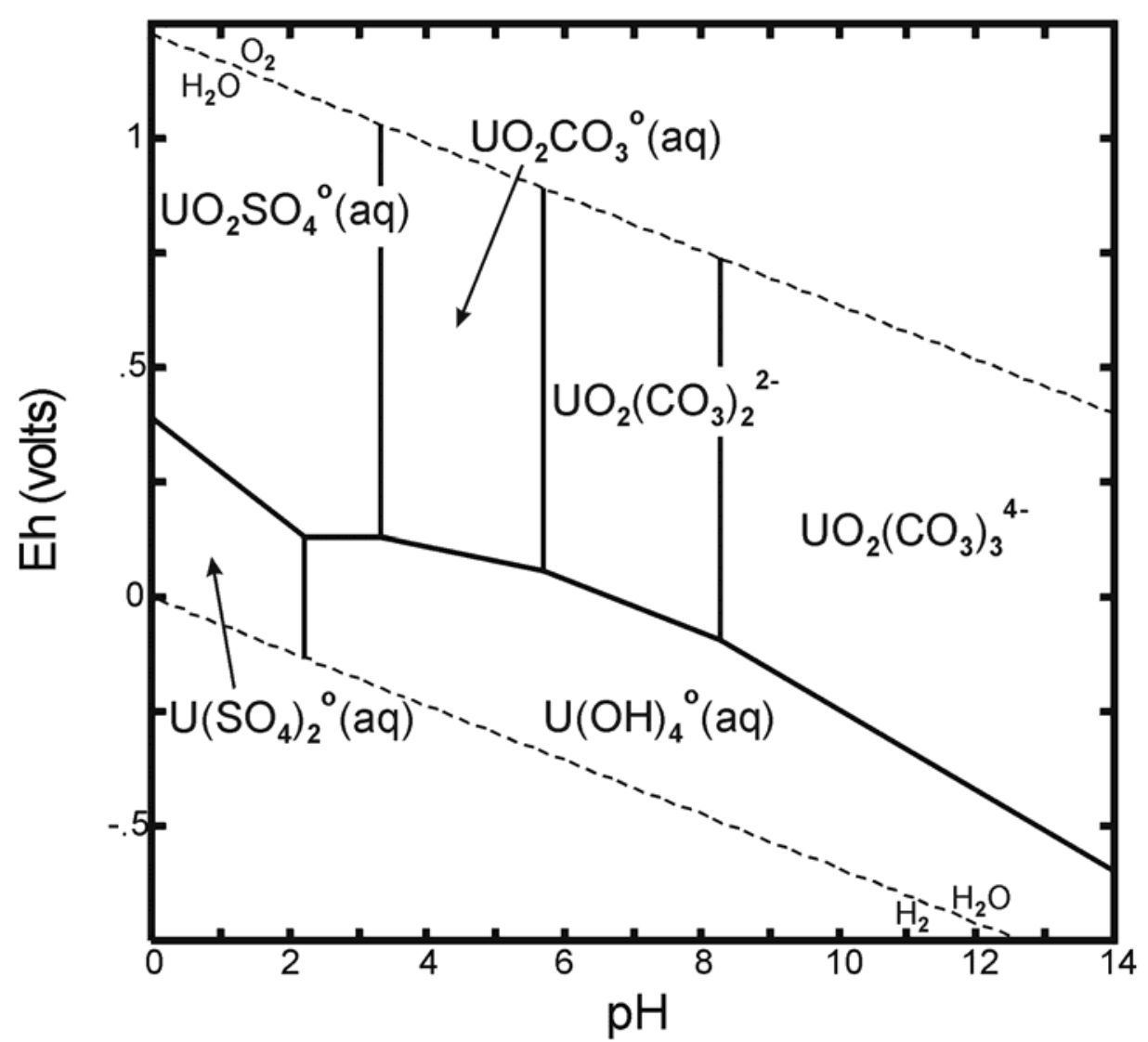

Figure 6.2. Eh-pH Diagram Showing the Dominant Aqueous Complexes of Uranium [Diagram was calculated at $25^{\circ} \mathrm{C}$ and a concentration of $10^{-7} \mathrm{~mol} / \mathrm{L}$ total dissolved uranium in the presence of dissolved chloride, nitrate, carbonate, and sulfate.]

Under reducing conditions or near a uranium source where elevated concentrations of uranium may exist, uranium mineral dissolution, precipitation, and coprecipitation processes become increasingly important and several uranium (co)precipitates may form depending on the environmental conditions (Finch and Murakami 1999; Falck 1991; Frondel 1958). These processes have a great effect on the concentrations of U(IV) in sediments, groundwaters, and geologic formations due to the low solubility of $\mathrm{U}(\mathrm{IV})$ under reducing conditions. Uraninite (compositions ranging from $\mathrm{UO}_{2}$ to $\mathrm{UO}_{2.25}$ ) and coffinite $\left(\mathrm{USiO}_{4}\right)$ are the two most important ore minerals of uranium (Langmuir 1997; Frondel 1958).

At a total concentration of uranium of $10^{-7} \mathrm{~mol} / \mathrm{L}(24 \mu \mathrm{g} / \mathrm{L})$, which is the total concentration of uranium used to calculate Figures 6.1 and 6.2, uraninite computes to be oversaturated under reducing conditions. Figure 6.3 was calculated at the same conditions as Figure 6.2 (total concentrations of uranium, chloride, nitrate, carbonate, and sulfate of $0.024,22,1.7,67.5$, and $108 \mathrm{mg} / \mathrm{L}$, respectively). Figure 6.3 shows the large Eh-pH region (shaded area) where the solubility of uraninite is exceeded under these conditions. Increasing the concentration of dissolved uranium expands the Eh-pH region of uraninite oversaturation to lower $\mathrm{pH}$ values and slightly higher oxidizing conditions. Thermodynamic 
calculations do not identify any potential solubility controls for dissolved U(VI) at the geochemical conditions used to determine Figure 6.3.

Mineral solubility processes are also important relative to the environmental behavior of U(VI) under oxidizing conditions near uranium sources, where elevated concentrations of uranium can exist. Typical environments would include, for example, the oxidation dissolution of uranium ore deposits, discharges of liquid wastes from uranium processing facilities or storage tanks, and disposal sites of uraniumcontaminated solids or soils. In these environments, potentially important mineral solubility controls for $\mathrm{U}(\mathrm{VI})$ include compreignacite $\left(\mathrm{K}_{2} \mathrm{U}_{6} \mathrm{O}_{19} \cdot 11 \mathrm{H}_{2} \mathrm{O}\right)$, uranophane $\left[\mathrm{Ca}\left(\mathrm{UO}_{2}\right)_{2}\left(\mathrm{SiO}_{3}\right)_{2}(\mathrm{OH})_{2} \cdot 5 \mathrm{H}_{2} \mathrm{O}\right]$, boltwoodite $\left[\mathrm{K}\left(\mathrm{H}_{3} \mathrm{O}\right) \mathrm{UO}_{2}\left(\mathrm{SiO}_{4}\right) \cdot 1.5 \mathrm{H}_{2} \mathrm{O}\right]$, sklodowskite $\left[\mathrm{Mg}\left(\mathrm{UO}_{2}\right)_{2}\left(\mathrm{SiO}_{3}\right)_{2}(\mathrm{OH})_{2} \cdot 5 \mathrm{H}_{2} \mathrm{O}\right]$, becquerelite $\left(\mathrm{CaU}_{6} \mathrm{O}_{19} \cdot 10 \mathrm{H}_{2} \mathrm{O}\right)$, carnotite $\left[\left(\mathrm{K}_{2}\left(\mathrm{UO}_{2}\right)_{2}\left(\mathrm{VO}_{4}\right)_{2} \cdot 3 \mathrm{H}_{2} \mathrm{O}\right]\right.$, schoepite $\left(\mathrm{UO}_{3} \mathrm{~A} 2 \mathrm{H}_{2} \mathrm{O}\right)$, rutherfordine $\left(\mathrm{UO}_{2} \mathrm{CO}_{3}\right)$, tyuyamunite $\left[\mathrm{Ca}\left(\mathrm{UO}_{2}\right)_{2}\left(\mathrm{VO}_{4}\right)_{2} \cdot 5-8 \mathrm{H}_{2} \mathrm{O}\right]$, autunite $\left[\mathrm{Ca}\left(\mathrm{UO}_{2}\right)_{2}\left(\mathrm{PO}_{4}\right)_{2} \cdot 10-12 \mathrm{H}_{2} \mathrm{O}\right]$, and potassium autunite $\left[\mathrm{K}_{2}\left(\mathrm{UO}_{2}\right)_{2}\left(\mathrm{PO}_{4}\right)_{2} \cdot 10-12 \mathrm{H}_{2} \mathrm{O}\right]$ (Langmuir 1997).

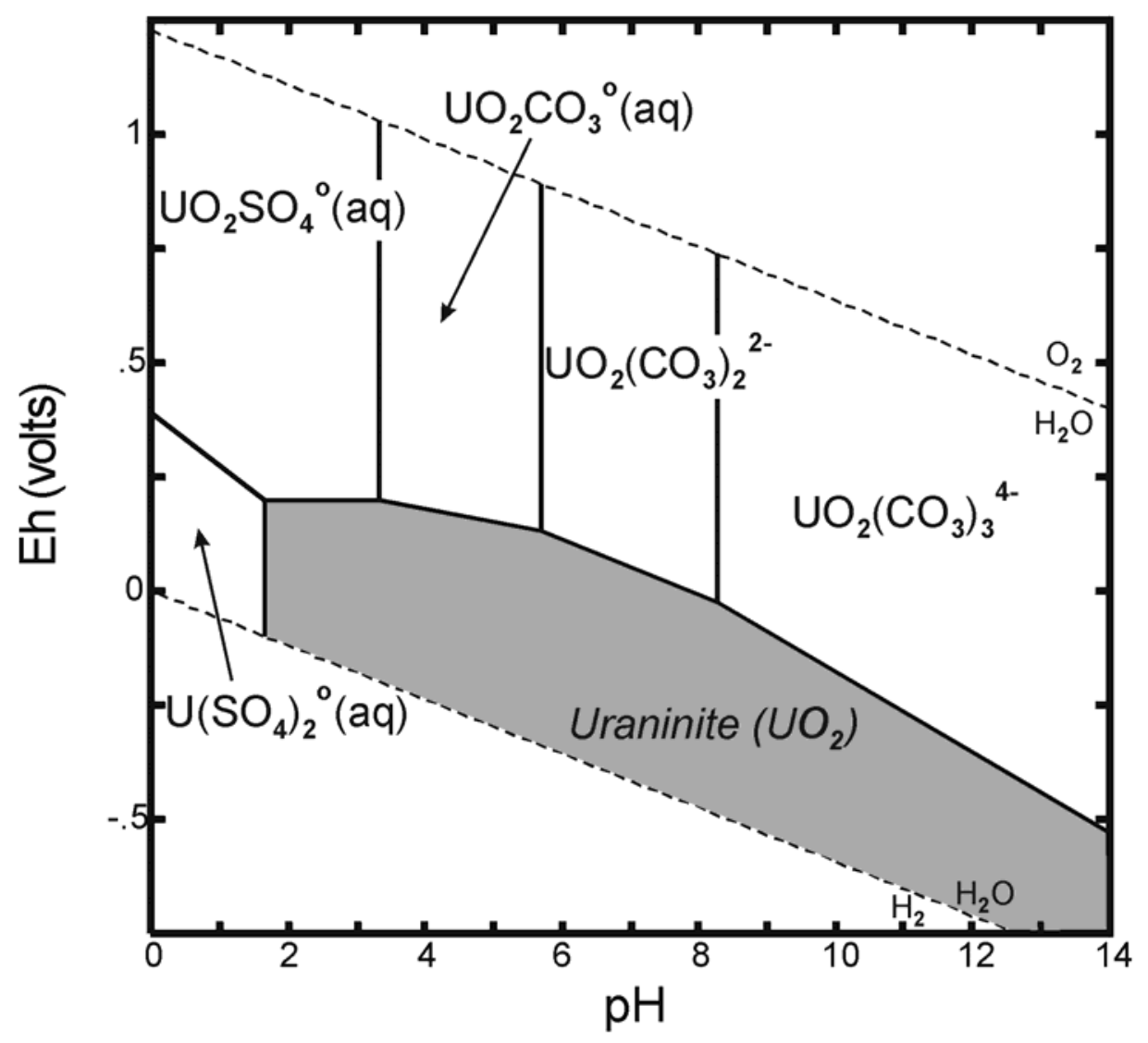

Figure 6.3. Eh-pH Diagram Showing Dominant Aqueous Species of Uranium and Eh-pH Region (Shaded Area) Where the Solubility of Uraninite Has Been Exceeded [Diagram was calculated at $25^{\circ} \mathrm{C}$ and a concentration of $10^{-7} \mathrm{~mol} / \mathrm{L}$ total dissolved uranium in the presence of dissolved chloride, nitrate, carbonate, and sulfate.] 
Near sources of uranium release, solubility processes are particularly important for those sediments that become partially saturated with water or completely dry between periods of recharge, such as the surface soils and vadose zone sediments. Under these conditions, the concentration of uranium in the residue pore fluids may exceed the solubility limits for $\mathrm{U}(\mathrm{VI})$-containing minerals and/or coprecipitates with other minerals, such as iron oxides. Characterization studies at DOE sites, such as the Hanford, Fernald, Oak Ridge, and Savannah River Sites, suggest that sediments and soils contaminated from disposal or spills of uranium-containing liquid wastes at these sites can contain uranium-containing minerals or coprecipitates [e.g., Zachara and coworkers. (2002a); Serne et al. (2002); Delegard et al. (1986); Buck et al. (1994, 1996); Morris et al. (1996); Roh et al. (2000); Bertsch et al. (1994); and Hunter and Bertsch (1998)].

A series of characterization studies by J. M. Zachara at PNNL and coworkers have been conducted to identify the form and oxidation state of uranium in samples of waste-contaminated sediment from a borehole (299-E33-45) that was drilled through the waste plume immediate to tank 241-BX-102 at the Hanford Site. The results of these studies indicate that uranium precipitated in the +6 valence state, and formed discrete particles or particle aggregates in the contaminated vadose zone sediments. McKinley et al. (2002) analyzed thin sections of the contaminated sediments from 241-BX-102 core using X-ray microprobe (XMP), X-ray absorption fine structure (XAFS), X-ray absorption near-edge structure (XANES), electron microprobe (EMP), and SEM. Their results showed that the uranium particles were typically 1 to $3 \mu \mathrm{m}$ in diameter, and occasionally formed radiating clusters of acicular crystals. McKinley et al. (2002) found that the uranium particles occurred in microfractures in the sediments, and did not exhibit any association with any specific sediment mineral phase(s) that could have been a surface catalyst for their precipitation. Their chemical analyses indicated that the uranium particles were composed of uranium, silicon, oxygen, sodium, and potassium. McKinley et al. (2002) suggested boltwoodite, sodium-boltwoodite $\left.\left[(\mathrm{Na}, \mathrm{K})\left(\mathrm{UO}_{2}\right)\left(\mathrm{SiO}_{3} \mathrm{OH}\right) \cdot 1.5 \mathrm{H}_{2} \mathrm{O}\right)\right]$, and weeksite $\left[\mathrm{K}_{1-\mathrm{x}} \mathrm{Na}_{\mathrm{x}}\left(\mathrm{UO}_{2}\right)_{2}\left(\mathrm{Si}_{5} \mathrm{O}_{13}\right) \cdot 4 \mathrm{H}_{2} \mathrm{O}\right]$ as possible identities of the uranium phases in the sediment samples. Catalano et al. (2002) used to XAFS spectroscopy and X-ray fluorescence microprobe analyses to investigate the speciation and spatial distribution of uranium in samples collected from the BX-102 borehole. Their study did not reveal any evidence for immobilization of uranium by in situ reduction in the sediments. The analyses by Catalano et al. (2002) indicated that the uranium particles were potentially composed of uranophane, boltwoodite, or a mixture or solid solution of these two minerals. Zachara et al. (2002b) used laser-induced fluorescence spectroscopy (LIFS) to characterize the uranium phases present in sediment samples from the BX-102 core. The results of their LIFS study indicated that the uranium particles in the sediments potentially consisted of a uranyl phosphate \{e.g., phosphuranylite $\left[\mathrm{KCa}\left(\mathrm{H}_{3} \mathrm{O}\right)_{3}\left(\mathrm{UO}_{2}\right)_{7}\left(\mathrm{PO}_{4}\right)_{4} \mathrm{O}_{4} \cdot 8 \mathrm{H}_{2} \mathrm{O}\right]$ or meta-autunite $\}$ or a uranyl silicate \{e.g., soddyite $\left[\left(\mathrm{UO}_{2}\right)_{2} \mathrm{SiO}_{4} \cdot 2 \mathrm{H}_{2} \mathrm{O}\right]$, uranophane, or boltwoodite $\}$.

Serne et al. (2002) have recently conducted characterization, leaching, and adsorption/desorption studies of uranium-contaminated sediments collected at near surface waste sites in the 300 Area at the Hanford Site. Scanning electron microscopy and molecular probe analyses indicate that uranium in the soil samples is likely present as co-precipitates and/or discrete uranium particles. The detailed analyses completed by Serne and coworkers to date however, have not determined the exact identification of the uranium phases. Their analyses indicate that uranium is present in the +6 valence state. The molecular probe data suggest that the crystalline uranium phases are most likely clarkeite 
PNNL-14126

$\left[(\mathrm{Na}, \mathrm{Ca}, \mathrm{Pb})_{2}\left(\mathrm{UO}_{2}\right) \mathrm{O}(\mathrm{OH}) \cdot 0-1 \mathrm{H}_{2} \mathrm{O}\right]$ or uranophane. Extended X-ray absorption fine structure (EXAFS) analyses suggest that the U(VI)-containing phases are likely uranyl phosphates and/or silicates based on the interatomic distance considerations. Laser fluorescence spectroscopy measurements however, indicate that the uranium-contaminated sediments do not contain uranyl phosphates. The investigators are currently continuing these analyses and their interpretation of the data to resolve the differences in the results from EXAFS and laser fluorescence spectroscopy.

Delegard et al. (1986) investigated the use of an ion exchange-based technique for removal of dissolved uranium from contaminated groundwater underlying the then newly activated 216-U-16 and the retired 216-U-1 and 216-U-2 liquid waste disposal cribs in the Separations Areas on the Hanford Site. Analysis of groundwater samples from area wells near these cribs indicated that the dissolved uranium was present as poorly adsorbing, aqueous anionic $\mathrm{U}(\mathrm{VI})$ carbonate complexes such as $\mathrm{UO}_{2}\left(\mathrm{CO}_{3}\right)_{2}{ }^{2-}(\mathrm{see}$ speciation in Figure 6.2). X-ray diffraction (XRD) analysis of sediment samples from well 299-W19-11 indicated that the mineralogy of the sediments consisted primarily of quartz, illite, and feldspar. Sediment taken at a depth of $10.8 \mathrm{~m}$ from well 299-W19-11 was also found to contain uranium precipitates in the form of meta-autunite. At the time of the studies by Delegard et al. (1986), the uranium in these sediments had been remobilized by water flow resulting from nearby disposal of cooling water.

Buck $(1994,1996)$ used analytical electron microscopy (AEM) combined with electron diffraction to identify meta-autunite $\left[\mathrm{Ca}\left(\mathrm{UO}_{2}\right)_{2}\left(\mathrm{PO}_{4}\right)_{2} \cdot 2-6 \mathrm{H}_{2} \mathrm{O}\right]$, uraninite, and uranium metaphosphate $\left[\mathrm{U}\left(\mathrm{PO}_{3}\right)_{4}\right]$ in uranium-contaminated soils from the DOE former uranium production facility at Fernald, Ohio. Morris et al. (1996) determined the presence of autunite-like ${ }^{\mathrm{a}}$ and schoepite-like mineral phases in uraniumcontaminated soils from Fernald. Their study used X-ray absorption, optical luminescence, and Raman vibrational spectroscopies along with energy dispersive scanning electron microscopy and powder X-ray diffraction to identify the uranium phases.

Roh et al. (2000) used X-ray diffraction (XRD) and scanning electron microscopy (SEM) with energy-dispersive X-ray spectroscopy (EDS) to examine soils from two uranium-contaminated sites (K311 and K1300) at the DOE K-25 site in Oak Ridge, Tennessee. The dominant uranium solids identified by Roh et al. (2000) were schoepite, uranophane, and coffinite from the K311 site soils, and U-Ca-oxide and U-Ca-phosphate solids at the K1300 site soils.

Bertsch et al. (1994) and Hunter and Bertsch (1998) examined uranium-contaminated soils from the DOE Savannah River Site near Aiken, South Carolina using micro-X-ray absorption and microfluorescence spectroscopy. Their studies indicated that no significant reduction of uranium had taken place in the contaminated sediments from the Savannah River Site, and the uranium was primarily associated with the organic and amorphous iron phases in the soils. The uranium was possibly present as amorphous hydroxyl-uranyl phases based on the fluorescence spectra (Hunter and Bertsch 1998).

a Autunite refers to a group of secondary $\mathrm{U}(\mathrm{VI})$ minerals of the general formula $\mathrm{R}^{2+}\left(\mathrm{UO}_{2}\right)_{2}\left(\mathrm{XO}_{4}\right)_{2} \cdot n \mathrm{H}_{2} \mathrm{O}$, where $\mathrm{R}=\mathrm{Ca}, \mathrm{Cu}, \mathrm{Mg}, \mathrm{Ba}, \mathrm{Na}_{2}$, and other metals, and $\mathrm{XO}_{4}=\mathrm{PO}_{4}$ or $\mathrm{AsO}_{4}$. 
PNNL-14126

\subsection{Adsorption}

The adsorption behavior of uranium on geologic materials has been the subject of extensive study. The majority of these studies deal with the adsorption of U(VI). Adsorption studies of U(IV) are limited relative to those for U(VI), because U(IV) is considered relatively immobile due to its low solubility under reducing conditions (Section 6.3). Studies of U(IV) adsorption typically have been conducted in support of safety assessments for the geologic disposal of high level radioactive waste in deep crystalline rock formations. These U(IV) adsorption studies were usually completed using crushed rock or single mineral phase(s) relevant to the geologic formation being characterized as candidate repository sites (EPA 1999b). Because such geologic materials are not relevant to sediments or soils present in the vadose zone, U(IV) adsorption studies will therefore not be discussed further in this report. As noted in Figures 6.1 and 6.2, the dominant U(IV) aqueous species are expected to be cationic and neutral over the complete $\mathrm{pH}$ range. Therefore, by analogy to the adsorption behavior determined for other metals present predominately as cationic and neutral aqueous species, the adsorption of U(IV) on sediment should be minimal at very acidic conditions, increase with increasing $\mathrm{pH}$ especially in the near-neutral $\mathrm{pH}$ range, and be at a maximum at basic $\mathrm{pH}$ conditions. The reader should note that uranium sorption measurements conducted under reducing conditions that resulted in very large adsorption (e.g., $\mathrm{K}_{\mathrm{d}}$ ) values were likely affected by U(IV) precipitation reactions and not representative of uranium adsorption on mineral surfaces. In experiments conducted using freshly crushed rock materials, uranium sorption measurements may have also been compromised unbeknownst to the investigators by reduction of U(VI) to U(IV) by surface-mediated reduction reactions with ferrous iron [Fe(II)] exposed on mineral surfaces (EPA 1999b).

\subsubsection{General Adsorption Behavior}

An extensive review of published uranium adsorption studies is given in EPA (1999b). Uranium(VI) adsorbs onto a variety of minerals and related phases, including clays (e.g., Ames et al. 1982; Chisholm-Brause et al. 1994), oxides and silicates (e.g., Hsi and Langmuir 1985; Waite et al. 1994), and natural organic material (e.g., Borovec et al. 1979; Shanbhag and Choppin 1981; Read et al. 1993). Important environmental parameters affecting uranium migration include oxidation/reduction conditions, $\mathrm{pH}$, concentrations of complexing ligands such as dissolved carbonate, ionic strength, and mineralogy.

As with the adsorption of most dissolved metals, aqueous $\mathrm{pH}$ has a significant effect on U(VI) adsorption due to the consequence of $\mathrm{pH}$ on $\mathrm{U}(\mathrm{VI})$ aqueous speciation and the number of exchange sites on variable charged surfaces of solids such as iron-, aluminum-oxides, and natural organic matter. Figure 6.4 is a modification of Figure J.4 that the authors of this report presented in EPA (1999b); it shows the distribution of $\mathrm{U}(\mathrm{VI}) \mathrm{K}_{\mathrm{d}}$ values reported in the literature as a function of $\mathrm{pH}$. The reader should note that the values on the $y$-axis in Figure 6.4 are given in $\log _{10}$ units. Depending on the adsorbent, the measured adsorption of U(VI) by sediments and single-mineral phases in carbonate-containing aqueous solutions is low at $\mathrm{pH}$ values less than 3 , increases rapidly with increasing $\mathrm{pH}$ from $\mathrm{pH} 3$ to 5 , reaches a maximum in adsorption in the $\mathrm{pH}$ range from $\mathrm{pH} 5$ to 7-8, and then decreases with increasing $\mathrm{pH}$ at $\mathrm{pH}$ values greater than 7 (Figure 6.4). This trend is similar to the in situ $\mathrm{K}_{\mathrm{d}}$ values reported by Serkiz and Johnson (1994), and percent adsorption values measured for uranium on single mineral phases such as those reported for iron oxides (Hsi and Langmuir 1985; Waite et al. 1992, 1994; Duff and Amrheim 1996), clays (Waite et al. 1992; McKinley et al. 1995; Turner et al. 1996), and quartz (Waite et al. 1992). 
The uranium $\mathrm{K}_{\mathrm{d}}$ values plotted in Figure 6.4 typically exhibit several orders of magnitude of scatter at any $\mathrm{pH}$ value. This scatter increases from approximately three orders of magnitude at $\mathrm{pH}$ values below $\mathrm{pH} 5$, to approximately three to four orders of magnitude from $\mathrm{pH} 5$ to 7, and approximately four to five orders of magnitude at $\mathrm{pH}$ values from $\mathrm{pH} 7$ to 9 . At the lowest and highest $\mathrm{pH}$ regions, it should be noted that one to two orders of the observed variability actually represent uranium $\mathrm{K}_{\mathrm{d}}$ values that are less than $10 \mathrm{~mL} / \mathrm{g}$. At $\mathrm{pH}$ values less than 3.5 and greater than 8, this variability includes $\mathrm{K}_{\mathrm{d}}$ values of less than $1 \mathrm{~mL} / \mathrm{g}$. A significant amount of this variation in $\mathrm{K}_{\mathrm{d}}$ values (Figure 6.4) at a given $\mathrm{pH}$ value is related to heterogeneity in the mineralogy of the soils and is an important factor relative to the adsorption behavior of U(VI). Soils containing larger percentages of iron oxide minerals and mineral coatings and/or clay minerals will exhibit higher sorption characteristics than soils dominated by quartz and feldspar minerals, such as found in Hanford Site sediments. This variability in uranium adsorption with respect to mineralogy is readily apparent from adsorption measurements for ferrihydrite, kaolinite, and quartz by Waite et al. (1992). However, most compilations of $\mathrm{K}_{\mathrm{d}}$ values and sorption information in general also incorporate diverse sources of errors resulting from different laboratory methods, soil and mineral types, length of equilibration (experiments conducted from periods of hours to weeks), and other factors. These sources of possible error are discussed in detail in EPA (1999a).

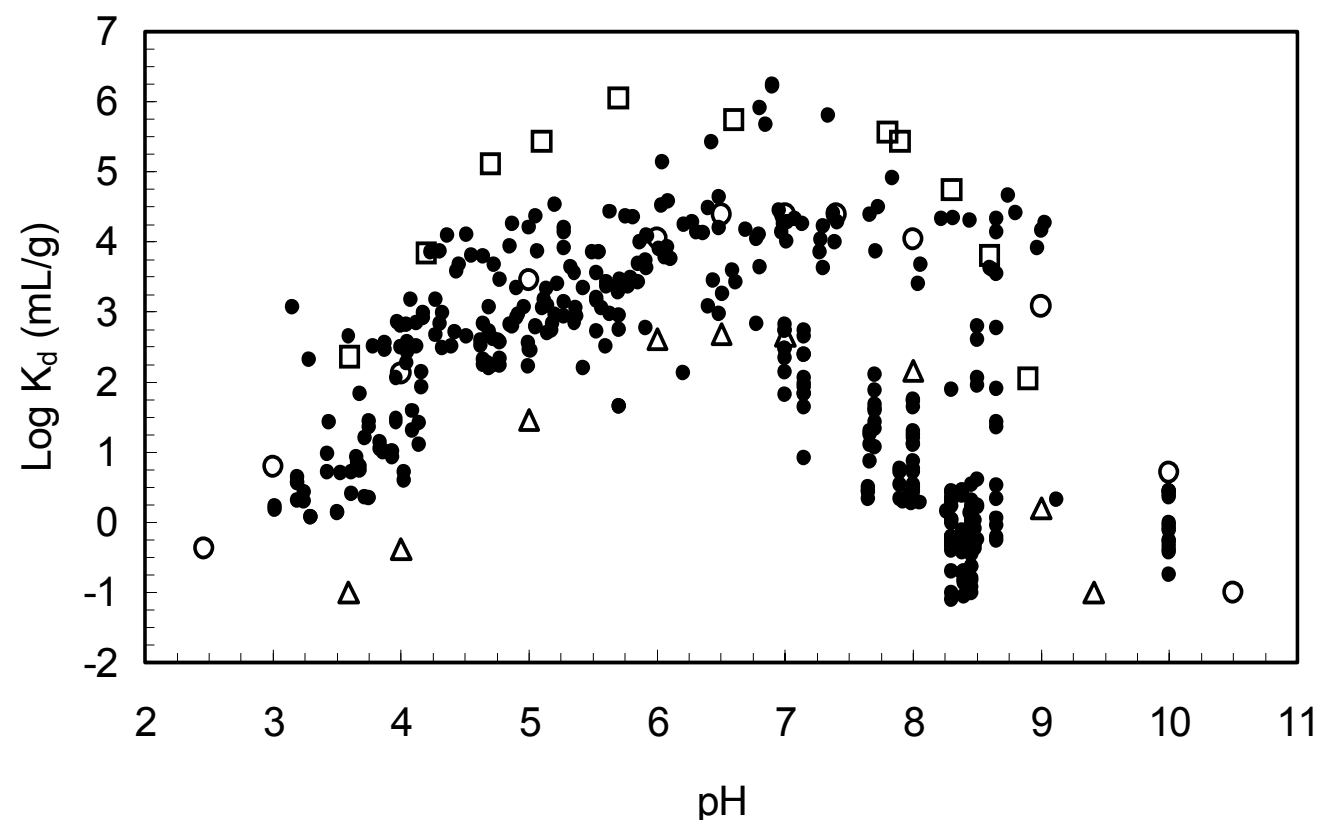

Figure 6.4. Distribution of $U(V I) K_{d}$ Values for Sediments and Single-Mineral Phases as a Function of $\mathrm{pH}$ in Carbonate-Containing Aqueous Solutions. [Filled circles represent $\mathrm{U}(\mathrm{VI}) \mathrm{K}_{\mathrm{d}}$ values compiled from the literature for sediments, and listed in Table J.5 in EPA (1999b). Open symbols represent $\mathrm{K}_{\mathrm{d}}$ maximum and minimum values estimated from uranium adsorption measurements plotted by Waite et al. (1992) for ferrihydrite (open squares), kaolinite (open circles), and quartz (open triangles).]

The observed increase in U(VI) adsorption onto sediments (Figure 6.4) from acidic to near neutral $\mathrm{pH}$ values is a consequence of the dominant $\mathrm{U}(\mathrm{VI})$ aqueous species being cationic and neutral (Figures 6.2) over this $\mathrm{pH}$ range. However, the subsequent decrease in $\mathrm{U}(\mathrm{VI})$ adsorption with increasing basic $\mathrm{pH}$ 
values results from the dominant $\mathrm{U}(\mathrm{VI})$ aqueous species being anionic $\mathrm{U}(\mathrm{VI})$ carbonate complexes as shown in Figure 6.2. In the absence of dissolved carbonate, uranium sorption to iron oxide and clay minerals has been shown to be extensive and remain at a maximum at $\mathrm{pH}$ values near and above neutral pH (Kent et al. 1988; Hsi and Langmuir 1985; Ames et al. 1982). However, in the presence of carbonate and organic complexants, U(VI) adsorption has been shown to be substantially reduced or inhibited. Surface complexation studies of uranium adsorption by Tripathi (1984), Hsi and Langmuir (1985), Waite et al. (1992, 1994), McKinley et al. (1995), Duff and Amrheim (1996), Turner et al. (1996), and others have shown that the formation of strong anionic U(VI) carbonate complexes decreases U(VI) adsorption at basic $\mathrm{pH}$ conditions. Even differences in partial pressures of $\mathrm{CO}_{2}$ have a major affect on uranium adsorption at neutral $\mathrm{pH}$ conditions. Waite et al (1992), for example, show that the percent of U(VI) adsorbed onto ferrihydrite decreases from approximately 97 to $38 \%$ when $\mathrm{CO}_{2}$ is increased from ambient $(0.03 \%)$ to elevated $(1 \%)$ partial pressures.

Kaplan et al. (1995) notes that U(VI) adsorption typically increases with increasing ionic strength of an oxidized aqueous solution. The presence of increasing concentrations of other dissolves ions, such as $\mathrm{Ca}^{2+}, \mathrm{Mg}^{2+}$, and $\mathrm{K}^{+}$, will displace the $\mathrm{U}(\mathrm{VI})$ ions adsorbed onto mineral surface sites, and release $\mathrm{U}(\mathrm{VI})$ into the aqueous solution. Therefore, the mobility of U(VI) is expected to increase in high ionic-strength solutions.

Naturally occurring organic matter in sediments and soils is also important in the adsorption of uranium. Several mechanisms have been proposed for U(VI) adsorption by organic matter (Kaplan et al. 1995). The adsorption of uranium to humic substances may occur through ion exchange and complexation processes that result in the formation of stable U(VI) complexes involving the acidic functional groups (Idiz et al. 1986; Boggs et al. 1985; Shanbhag and Choppin 1981; Borovec et al. 1979). Alternatively, Nash et al. (1981) has suggested that organic material may act to reduce dissolved U(VI) species to U(IV).

\subsubsection{Surface Complexation Models}

Numerous laboratory and modeling studies have been conducted using surface complexation of uranium onto single mineral phases. Electrostatic surface complexation models (SCMs) were developed to provide a mechanistic description of the adsorption of metals onto mineral surfaces. ${ }^{\text {a }}$ Electrostatic surface complexation models have been incorporated into several geochemical modeling/reaction codes, such as MINTEQA2 (Allison et al. 1991), and can be used to predict U(VI) adsorption behavior and $\mathrm{K}_{\mathrm{d}}$ values for certain mineral phases as a function of key geochemical parameters such as $\mathrm{pH}$ and dissolved carbonate concentrations. The current state of knowledge and availability of constants for using electrostatic surface complexation models to calculate the adsorption of uranium onto important soil

a Detailed descriptions, comparisons, and derivations of the relevant equations and reactions associated with electrostatic surface complexation models are described in Westall and Hohl (1980), Morel et al. (1981), Barrow and Bowden (1987), Davis and Kent (1990), Langmuir (1997), and others.

Electrostatic surface complexation models typically incorporated into geochemical models include the diffuse layer model (DLM) [or diffuse double layer model (DDLM)], constant capacitance model (CCM), Basic Stern model, and triple layer model (TLM). 
minerals is probably as advanced as those for any other trace metal. These include studies of uranium adsorption onto iron oxides (Tripathi 1984; Hsi and Langmuir 1985; Waite et al. 1992, 1994; Duff and Amrheim 1996; and others), clays (Waite et al. 1992; McKinley et al. 1995; Turner et al. 1996; and others), and quartz (Waite et al. 1992, and others).

Barnett et al. (2002) recently used batch adsorption experiments and a surface complexation model to study the $\mathrm{pH}$-dependent adsorption of $\mathrm{U}(\mathrm{VI})$ on sediment and soil samples from the Oak Ridge, Savannah River, and Hanford Sites. The sediment sample from the Hanford Site was from the Upper Ringold Formation, and was obtained from the White Bluffs area above the Columbia River. Barnett et al. (2002) used the surface complexation model developed for the U(VI) adsorption onto ferrihydrite by Waite et al. (1994) to predict $\mathrm{U}(\mathrm{VI})$ adsorption on these sediments as a function of $\mathrm{pH}$. Application of this model necessitated that Barnett et al. (2002) assume that all of the dithionite-citrate-bicarbonate extractable iron oxides in these sediment samples were present as ferrihydrite. The modeling results of Barnett et al. (2002) qualitatively predicted the main characteristics of the $\mathrm{pH}$-dependent adsorption of U(VI) on these sediments in carbonate-containing systems. Barnett et al. (2002) suggested that this modeling approach could be used to assess the relative mobility of U(VI) in geochemical systems by indicating whether U(VI) was weakly or strongly adsorbed onto the geologic materials. Surface complexation models will likely receive increased use in the future in developing a better understanding of surface reactions and site conceptual models and in estimating limiting $\mathrm{K}_{\mathrm{d}}$ values for the adsorption of metals, especially for uranium, in the vadose zone and other geochemical environments.

\subsubsection{Hanford Sediment U(VI) Adsorption Studies}

Several studies of the adsorption of U(VI) on sediments from the Hanford Site have been completed. Recent studies include those by Zachara et al. (1992), Serne et al. (1993), Kaplan and Serne (1995), Lindenmeier et al. (1995), Kaplan et al. (1996), Gamerdinger et al. (1998), and Kaplan et al. (1998). Cantrell et al. (2002) has recently compiled $\mathrm{K}_{\mathrm{d}}$ values reported in U(VI) adsorption studies using Hanford Site sediments by Serne et al. (1993), Kaplan et al. (1996), Lindenmeier et al. (1995), Gamerdinger et al. (1998), and Kaplan et al. (1998). Cantrell et al. (2002) concluded that uranium adsorption is relatively low for natural groundwater conditions at the Hanford Site and a range of $K_{d}$ values from 0.2 to $4 \mathrm{~mL} / \mathrm{g}$ is appropriate for these conditions.

Kaplan et al. (1998) investigated the effects of U(VI) concentration, $\mathrm{pH}$, and ionic strength on the adsorption of $\mathrm{U}(\mathrm{VI})$ to a natural sediment containing carbonate minerals. The sediments used for the adsorption measurements were samples of a silty loam and a very coarse sand taken, respectively, from Trenches AE-3 and 94 at the Hanford Site. Groundwater collected from an uncontaminated part of the Hanford Site was equilibrated with each sediment in a ratio of $2 \mathrm{~mL} / 1 \mathrm{~g}$ for 14 or 30 days. The adsorption of U(VI) was determined to be constant for concentrations between 3.3 and $100 \mu \mathrm{g} / \mathrm{L} \mathrm{UO}_{2}{ }^{2+}$ at $\mathrm{pH} 8.3$ and an ionic strength of $0.02 \mathrm{M}$. This result indicates that a linear $\mathrm{K}_{\mathrm{d}}$ model could be used to describe the adsorption of $\mathrm{U}(\mathrm{VI})$ at these conditions. In those experiments where the $\mathrm{pH}$ was greater than 10 , precipitation of $\mathrm{U}(\mathrm{VI})$-containing solids occurred, which resulted in apparent $\mathrm{K}_{\mathrm{d}}$ values greater than $400 \mathrm{~mL} / \mathrm{g}$.

Gamerdinger et al. (1998) conducted a series of experiments using an unsaturated flow apparatus $\left(\mathrm{UFA}^{\mathrm{TM}}\right)$ to measure the adsorption and mobility of U(VI) under partial moisture saturation conditions 
that are relevant to waste burial sites and vadose-zone far-field conditions at the Hanford Site. The sediments used for these measurements included samples of a medium coarse sand, a Touchet bed fine sand, and a Warden silt loam. The experiments were conducted with uncontaminated groundwater with pH 8.4 from the Hanford Site. For the conditions considered for their experiments, Gamerdinger et al. (1998) determined that $\mathrm{U}(\mathrm{VI}) \mathrm{K}_{\mathrm{d}}$ values decreased with decreasing moisture saturation irrespective of sediment texture. The $\mathrm{K}_{\mathrm{d}}$ values determined by Gamerdinger et al. (1998) for the medium coarse sand decreased from 0.48 to $0.16 \mathrm{~mL} / \mathrm{g}$ at moisture saturations from 30 to $12 \%$, respectively. For the fine sand, the $\mathrm{U}(\mathrm{VI}) \mathrm{K}_{\mathrm{d}}$ values were 1.42 and $0.39 \mathrm{~mL} / \mathrm{g}$ at moisture saturations of 66 and 22\%, respectively. For the silt loam, the $\mathrm{U}(\mathrm{VI}) \mathrm{K}_{\mathrm{d}}$ values were 4.05 and $1.81 \mathrm{~mL} / \mathrm{g}$ at moisture saturations of 83 and $41 \%$, respectively.

Kaplan et al. (1996) measured the $K_{d}$ values for U(VI) and several other radionuclides at geochemical conditions being considered in a performance assessment for the long-term disposal of radioactive low-level waste in the unsaturated zone at the Hanford Site. The studies included an evaluation of the effects of $\mathrm{pH}$, ionic strength, moisture content, and radionuclide concentration on radionuclide adsorption behavior. The measurements were conducted using uncontaminated $\mathrm{pH} 8.46$ groundwater and the $<2$-mm size fraction of sediment samples collected from the Hanford Site. The sediment samples included TBS-1 Touchet Bed sand, Trench AE-3 silty loam, Trench- 8 medium coarse sand, and Trench-94 very coarse sand. For the concentration range from 3.3 to $100 \mu \mathrm{g} / \mathrm{L}$ dissolved uranium, the $\mathrm{U}(\mathrm{VI}) \mathrm{K}_{\mathrm{d}}$ values were constant. The $\mathrm{U}(\mathrm{VI}) \mathrm{K}_{\mathrm{d}}$ values increased from 1.1 to $2.2 \mathrm{~mL} / \mathrm{g}$ for $\mathrm{pH}$ values of 8 and 10 , respectively, for these site-specific sediments and geochemical conditions. Kaplan et al. (1996) noted that, at $\mathrm{pH}$ values above approximately 10 , the measured $\mathrm{K}_{\mathrm{d}}$ values were affected by precipitation of uranium solids. Their measurements also indicated that $\mathrm{U}(\mathrm{VI}) \mathrm{K}_{\mathrm{d}}$ values varied as a function of moisture content, although the trend differed based on sediment type.

Kaplan and Serne (1995) reported $\mathrm{K}_{\mathrm{d}}$ values for the adsorption of uranium on loamy sand sediment taken from Trench 8 at the Hanford Site. The measurements were made using a column technique at unsaturated conditions ( 7 to $40 \%$ saturated), neutral-to-high $\mathrm{pH}$, low organic material concentrations, and low ionic strength $(\mathrm{I} \leq 0.1)$. The aqueous solutions consisted of a sample of uncontaminated groundwater from the Hanford Site. The $\mathrm{K}_{\mathrm{d}}$ values ranged from 0.08 to $2.81 \mathrm{~mL} / \mathrm{g}$, and typically increase with increasing degree of column saturation.

Lindenmeier et al. (1995) conducted a series of flow-through column tests to evaluate contaminant transport of several radionuclides through sediments under unsaturated (vadose zone) conditions. The sediments were from the Trench 8 (W-5 Burial Ground) at the Hanford Site. The column tests were run using the $<2$-mm size fraction of the sediment and a site-specific groundwater. The results of the column tests indicated that the $\mathrm{K}_{\mathrm{d}}$ values for uranium on this sediment material decrease as the sediment becomes less saturated. A $\mathrm{K}_{\mathrm{d}}$ value of $2 \mathrm{~mL} / \mathrm{g}$ was determined from a saturated column test conducted at a pore water velocity of $1.0 \mathrm{~cm} / \mathrm{h}$ and residence time of $1.24 \mathrm{~h}$. However, at $29 \%$ water saturation, the measured $\mathrm{K}_{\mathrm{d}}$ value decreases by $70 \%$ to $0.6 \mathrm{~mL} / \mathrm{g}$ (pore water velocity of $0.3 \mathrm{~cm} / \mathrm{h}$ and residence time of $20.6 \mathrm{~h}$ ).

Serne et al. (1993) determined $K_{d}$ values for uranium and several other radionuclides at geochemical conditions associated with sediments at the Hanford Site. The $\mathrm{K}_{\mathrm{d}}$ values were measured using the batch technique with a well-characterized $\mathrm{pH} 8.3$ groundwater and the $<2$-mm size fraction of 3 wellcharacterized sediment samples from the Hanford Site. The sediment samples included TBS-1 Touchet 
PNNL-14126

Bed sand, CSG-1 coarse sand/gravel, and Trench- 8 medium coarse sand. The average $\mathrm{K}_{\mathrm{d}}$ values tabulated for uranium in Serne et al. (1993) are 1.70, 2.30, and 79.30, respectively, for the CSG-1, Trench-8, and TBS-1 sediment samples.

Zachara et al. (1992) studied the adsorption of U(VI) on clay-mineral separates from subsurface soils from three DOE sites. The mineral samples included the clay separates $(<2 \mu \mathrm{m}$ fraction) from the Kenoma Formation at the Fernald Site in Ohio, the Ringold Formation at the Hanford Site, and the Cape Fear Formation at the Savannah River Site in South Carolina. Prior to the measurements, the clay separates were treated with dithionite-citrate buffer and hydrogen peroxide to remove amorphous ferric hydroxides and organic materials. The measurements used clay suspensions ( $\sim 1$ meq of charge/L) spiked with $2 \mathrm{mg} / \mathrm{L}(8.6 \mu \mathrm{mol} / \mathrm{L})$ uranium and $\mathrm{Ca}\left(\mathrm{ClO}_{4}\right)_{2}$ or $\mathrm{NaClO}_{4}$ as the electrolyte. The $\mathrm{pH}$ values of the suspensions were adjusted over the $\mathrm{pH}$ range from 4.5 to 9.0 using sodium hydroxide. The measurements were completed in a glovebox under an inert atmosphere to eliminate effects from aqueous complexation of U(VI) by dissolved carbonate. The adsorption results for the Cape Fear clay isolate were essentially the same as those for the Kenoma clay (Zachara et al. 1992). The results for the Kenoma clay isolate show a strong dependence of uranium adsorption as a function of ionic strength that is opposite to that expected for competitive sorption between uranium and the electrolyte cation. Zachara et al. (1992) suggest that this increase in uranium adsorption with increasing ionic strength may be due to the ionic strength dependence of the hydrolysis of the uranyl ion.

\subsection{References}

Allison JD, DS Brown, and KJ Novo-Gradac. 1991. MINTEQA2/PRODEFA2, A Geochemical Assessment Model for Environmental Systems: Version 3.0 User's Manual. EPA/600/3-91/021, U.S. Environmental Protection Agency, Athens, Georgia.

Ames LL, JE McGarrah, BA Walker, and PF Salter. 1982. "Sorption of Uranium and Cesium by Hanford Basalts and Associated Secondary Smectite.” Chemical Geology, 35:205-225.

Barnett MO, PM Jardine, SC Brooks, and HM Selim. 2000. “Adsorption and Transport of Uranium(VI) in Subsurface Media.” Soil Science Society of America Journal, 64:908-917.

Barnett MO, PM Jardine, and SC Brooks. 2002. "U(VI) Adsorption to Heterogeneous Subsurface Media: Application of a Surface Complexation Model." Environmental Science and Technology, 36:937-942.

Barrow NJ and JW Bowden. 1987. "A Comparison of Models for Describing the Adsorption of Anions on a Variable Charge Mineral Surface.” Journal of Colloid and Interface Science, 119:236-250.

Bertsch PM, DB Hunter, SR Sutton, S Bajt, and ML Rivers. 1994. "In Situ Chemical Speciation of Uranium in Soils and Sediments by Micro X-ray Absorption Spectroscopy." Environmental Science and Technology, 28:980-984. 
PNNL-14126

Boggs S, Jr, D Livermore, and MG Seitz. 1985. Humic Substances in Natural Waters and Their Complexation with Trace Metals and Radionuclides: A Review. ANL-84-78, Argonne National Laboratory, Argonne, Illinois.

Borovec Z, B Kribek, and V Tolar. 1979. "Sorption of Uranyl by Humic Acids." Chemical Geology, 27:39-46.

Buck EC, NR Brown, and NL Dietz. 1994. "Distribution of Uranium-Bearing Phases in Soils from Fernald." In Scientific Basis for Nuclear Waste Management XVII, A Barkatt and RA Van Konynenburg (eds.), pp. 437-444. Materials Research Society Symposium Proceedings, Volume 333, Materials Research Society, Pittsburgh, Pennsylvania.

Buck EC, NR Brown, and NL Dietz. 1996. "Contaminant Uranium Phases and Leaching at the Fernald Site in Ohio." Environmental Science \& Technology, 30:81-88.

Burns PC and R Finch (eds.). 1999. Uranium: Mineralogy, Geochemistry and the Environment. Reviews in Mineralogy. Volume 38. Mineralogical Society of America, Washington, D.C.

Cantrell KJ, RJ Serne, and GV Last. 2002. Hanford Contaminant Distribution Coefficient Database and Users Guide. PNNL-13895, Pacific Northwest National Laboratory, Richland, Washington.

Catalano JG, JM Zachara, and GE Brown, Jr. 2002. "Appendix Section D.3.3. X-ray Spectroscopic Investigation of the Distribution and Speciation of Uranium in Samples from the BX-102 Borehole." In "Appendix D. Digest of Science and Technology Program Evaluations" in Field Investigation Report for Waste Management Area B-BX-BY. Volume 2, Appendices, AJ Knepp, pp. D-140 to D-160. RPP-10098, CH2M HILL Hanford Group, Inc., Richland, Washington.

Chisholm-Brause C, SD Conradson, CT Buscher, PG Eller, and DE Morris. 1994. "Speciation of uranyl Sorbed at Multiple Binding Sites on Montmorillonite." Geochimica et Cosmochimica Acta, 58(17):3625-3631.

Davis JA and DB Kent. 1990. "Surface Complexation Modeling in Aqueous Geochemistry." In Mineral-Water Interface Geochemistry, MF Hochella, Jr. and AF White (eds.), pp. 177-260, Reviews in Mineralogy, Volume 23, Mineralogical Society of America, Washington, D.C.

Delegard CH, RL Weiss, RT Kimura, AG Law, and RC Routson. 1986. "Characterization and Anion Exchange Removal of Uranium from Hanford Ground Water.” In Waste Management'86, Volume 1, RG Post (ed.), pp. 545-550. Arizona Board of Regents, Arizona.

Duff MC and C Amrhein. 1996. "Uranium(VI) Adsorption on Goethite and Soil in Carbonate Solutions.” Soil Science Society of America Journal, 60(5):1393-1400.

EPA(U.S. Environmental Protection Agency). 1999a. Understanding Variation in Partition Coefficient, $K_{d}$, Values: Volume I. The $K_{d}$ Model, Methods of Measurement, and Application of Chemical Reaction Codes. EPA 402-R-99-04A, prepared for the U.S. Environmental Protection Agency, Washington, D.C. by Pacific Northwest National Laboratory, Richland, Washington. 
EPA(U.S. Environmental Protection Agency). 1999b. Understanding Variation in Partition Coefficient, $K_{d}$, Values: Volume II. Review of Geochemistry and Available $K_{d}$ Values for Cadmium, Cesium,

Chromium, Lead, Plutonium, Radon, Strontium, Thorium, Tritium ${ }^{3} H$ ), and Uranium.

EPA 402-R-99-004B, prepared for the U.S. Environmental Protection Agency, Washington, D.C. by Pacific Northwest National Laboratory, Richland, Washington.

Falck WE. 1991. CHEMVAL Project. Critical Evaluation of the CHEMVAL Thermodynamic Database with Respect to its Contents and Relevance to Radioactive Waste Disposal at Sellafield and Dounreay. DoE/HMIP/RR/92.064, Department of Environment, Her Majesty's Stationary Office, London, England.

Finch R and T Murakami. 1999. "Systematics and Paragenesis of Uranium Minerals." In Uranium: Mineralogy, Geochemistry and the Environment. Reviews in Mineralogy. Volume 38, PC Burns and R Finch (eds.), pp. 91-179. Mineralogical Society of America, Washington, D.C.

Frondel C. 1958. Systematic Mineralogy of Uranium and Thorium. Geological Survey Bulletin 1064, U.S. Geological Survey, Washington, D.C.

Gamerdinger AP, CT Resch, and DI Kaplan. 1998. Uranium (VI) Sorption and Transport in Unsaturated, Subsurface Hanford Site Sediments - Effect of Moisture Content and Sediment Texture: Final Report for Subtask 2b. PNNL-11975, Pacific Northwest National Laboratory, Richland, Washington.

Grenthe I, J Fuger, RJM Konings, RJ Lemire, AB Muller, C Nguyen-Trung, H Wanner. 1992. Chemical Thermodynamics 1: Chemical Thermodynamics of Uranium. North-Holland, Elsevier Science Publishing Company, Inc., New York, New York.

Grenthe I, I Puigdomenech, MCA Sandino, and MH Rand. 1995. “Appendix D - Chemical Thermodynamics of Uranium." In Chemical Thermodynamics 2: Chemical Thermodynamics of Americium, pp. 347-374. North-Holland, Elsevier Science Publishing Company, Inc., New York, New York.

Hsi C-KD and D Langmuir. 1985. "Adsorption of Uranyl Onto Ferric Oxyhydroxides: Application of the Surface Complexation Site-Binding Model.” Geochimica et Cosmochimica Acta, 49:1931-1941.

Hunter DB and PM Bertsch. 1998. "In Situ Examination of Uranium Contaminated Soil Particles by Micro-X-ray Absorption and Micro-Fluorescence Spectroscopies." Journal of Radioanalytical and Nuclear Chemistry, 234:237-242.

Idiz EF, D Carlisle, and IR Kaplan. 1986. "Interaction Between Organic Matter and Trace Metals in a Uranium Rich Bog, Kern County, California, U.S.A.” Applied Geochemistry, 1:573-590.

Kaplan DI and RJ Serne. 1995. Distribution Coefficient Values Describing Iodine, Neptunium, Selenium, Technetium, and Uranium Sorption to Hanford Sediments." PNL-10379 (Supplement 1), Pacific Northwest Laboratory, Richland, Washington. 
Kaplan DI, RJ Serne, and MG Piepho. 1995. Geochemical Factors Affecting Radionuclide Transport Through Near and Far Fields at a Low-Level Waste Disposal Site. PNNL-10379, Pacific Northwest National Laboratory, Richland, Washington.

Kaplan DI, RJ Serne, AT Owen, J Conca, TW Wietsma, and TL Gervais. 1996. Radionuclide Adsorption Distribution Coefficient Measured in Hanford Sediments for the Low Level Waste Performance Assessment Project. PNNL-11385, Pacific Northwest National Laboratory, Richland, Washington.

Kaplan DI, TL Gervais, and KM Krupka. 1998. "Uranium(VI) Sorption to Sediments Under High pH and Ionic Strength Conditions." Radiochimica Acta, 80:201-211.

Kent DB, VS Tripathi, NB Ball, JO Leckie, and MD Siegel. 1988. Surface-Complexation Modeling of Radionuclide Adsorption in Subsurface Environments. NUREG/CR-4807, U.S. Nuclear Regulatory Commission, Washington, D.C.

Knepp AJ. 2002. Field Investigation Report for Waste Management Area B-BXBY, RPP-10098, CH2M HILL Hanford Group, Inc., Richland, Washington.

Langmuir D. 1978. "Uranium Solution-Mineral Equilibria at Low Temperatures with Applications to Sedimentary Ore Deposits." Geochimica et Cosmochimica Acta, 42:547-569

Langmuir D. 1997. Aqueous Environmental Geochemistry. Prentice Hall, Upper Saddle River, New Jersey.

Lindenmeier CW, RJ Serne, JL Conca, AT Owen, and MI Wood. 1995. Solid Waste Leach Characteristics and Contaminant-Sediment Interactions Volume 2: Contaminant Transport Under Unsaturated Moisture Contents. PNL-10722, Pacific Northwest Laboratory, Richland, Washington.

Lovley DR. 1993. “Dissimilatory Metal Reduction.” Annual Review of Microbiology, 47:263-290.

Lovley DR. 1995. "Bioremediation of Organic and Metal Contaminants with Dissimilatory Metal Reduction." Journal of Industrial Microbiology, 14:85-93.

McKinley JP, JM Zachara, SC Smith, and GD Turner. 1995. "The Influence of Uranyl Hydrolysis and Multiple Site-Binding Reactions on Adsorption of U(VI) to Montmorillonite." Clays and Clay Minerals, 43(5):586-598.

McKinley JP, SM Heald, JM Zachara, and CT Resch. 2002. “Appendix Section D.3.2. The Identification of Uranium-Bearing Phases by X-ray Microprobe, Electron Microprobe, and Scanning Electron Microscopy.” In “Appendix D. Digest of Science and Technology Program Evaluations” in Field Investigation Report for Waste Management Area B-BX-BY. Volume 2, Appendices, AJ Knepp, pp. D-122 to D-139. RPP-10098, CH2M HILL Hanford Group, Inc., Richland, Washington. 
Morel FMM, JG Yeasted, and JC Westall. 1981. "Adsorption Models: A Mathematical Analysis in the Framework of General Equilibrium Calculations." In Adsorption of Inorganics at Solid-Liquid Interfaces, MA Anderson and AJ Rubin (eds.), pp. 263-294, Ann Arbor Science Publishers, Inc., Ann Arbor, Michigan.

Morris DE, PG Allen, JM Berg, CJ Chisholm-Brause, SD Conradson, RJ Donohoe, NJ Hess, JA Musgrave, and C Drew Tait. 1996. "Speciation of Uranium in Fernald Soils by Molecular Spectroscopic Methods: Characterization of Untreated Soils." Environmental Science and Technology, 30:2322-2331.

Nash K, S Fried, AM Freidman, and JC Sullivan. 1981. "Redox Behavior, Complexing, and Adsorption of Hexavalent Actinides by Humic Acid and Selected Clays." Environmental Science and Technology, 15:834-837.

Read D, TA Lawless, RJ Sims, and KR Butter. 1993. "Uranium Migration Through Intact Sandstone Cores." Journal of Contaminant Hydrology, 13:277-289.

Roh Y, SR Lee, SK Choi, MP Elless, and SY Lee. 2000. "Physicochemical and Mineralogical Characterization of Uranium-Contaminated Soils." Soil and Sediment Contamination, 9:463-486.

Serkiz SM and WH Johnson. 1994. Uranium Geochemistry in Soil and Groundwater at the F and H Seepage Basins (U). EPD-SGS-94-307, Westinghouse Savannah River Company, Savannah River Site, Aiken, South Carolina.

Serne RJ, JL Conca, VL LeGore, KJ Cantrell, CW Lindenmeier, JA Campbell, JE Amonette, and MI Wood. 1993. Solid-Waste Leach Characteristics and Contaminant-Sediment Interactions. Volume 1: Batch Leach and Adsorption Tests and Sediment Characterization. PNL-8889, Volume 1, Pacific Northwest Laboratory, Richland, Washington.

Serne RJ, CF Brown, HT Schaef, EM Pierce, MJ Lindberg, Z Wang, P Gassman, and J Catalano. 2002. 300 Area Uranium Leach and Adsorption Project. PNNL-14022, Pacific Northwest National Laboratory, Richland, Washington.

Smith DK. 1984. "Uranium Mineralogy.” In Uranium Geochemistry, Mineralogy, Geology, Exploration and Resources, B DeVero, F Ippolito, G Capaldi, and PR Simpson (eds.) pp. 43-88. Institution of Mining and Metallurgy, London, England.

Suzuki Y and JF Banfield. 1999. “Geomicrobiology of Uranium.” In Uranium: Mineralogy, Geochemistry and the Environment. Reviews in Mineralogy. Volume 38, PC Burns and R Finch (eds.), pp. 393-432. Mineralogical Society of America, Washington, D.C.

Shanbhag PM and GR Choppin. 1981. "Binding of Uranyl by Humic Acid." Journal of Inorganic Nuclear Chemistry, 43:3369-3372.

Tripathi VS. 1984. Uranium(VI) Transport Modeling: Geochemical Data and Submodels. Ph.D. Dissertation, Stanford University, Stanford, California. 
PNNL-14126

Turner GD, JM Zachara, JP McKinley, and SC Smith. 1996. "Surface-Charge Properties and $\mathrm{UO}_{2}{ }^{2+}$ Adsorption of a Subsurface Smectite." Geochimica et Cosmochimica Acta, 60(18):3399-3414.

Waite TD, TE Payne, JA Davis, and K Sekine. 1992. Alligators Rivers Analogue Project. Final Report Volume 13. Uranium Sorption. ISBN 0-642-599394 (DOE/HMIP/RR/92/0823, SKI TR 92:20-13).

Waite TD, JA Davis, TE Payne, GA Waychunas, and N Xu. 1994. "Uranium(VI) Adsorption to Ferrihydrite: Application of a Surface Complexation Model." Geochimica et Cosmochimica Acta, 58(24):5465-5478.

Westall JC and H Hohl. 1980. "A Comparison of Electrostatic Models for the Oxide/Solution Interface." Advances in Colloid and Interface Science, 12:265-294.

Zachara JM, CC Ainsworth, JP McKinley, EM Murphy, JC Westall, and PSC Rao. 1992. "Subsurface Chemistry of Organic Ligand-Radionuclide Mixtures." In Pacific Northwest Laboratory Annual Report for 1991 to the DOE Office of Energy Research. Part 2: Environmental Science, pp. 1-12. PNL-8000 Part 2, Pacific Northwest Laboratory, Richland, Washington.

Zachara JM and coworkers. 2002a. "Appendix D. Digest of Science and Technology Program Evaluations." In Field Investigation Report for Waste Management Area B-BX-BY. Volume 2, Appendices, AJ Knepp, pp. D-i to D-306, RPP-10098, CH2M HILL Hanford Group, Inc., Richland, Washington.

Zachara JM, Z Wang, PL Gassman, C Liu, and JG Catalano. 2002b. “Appendix Section D.3.4. Fluorescence Spectroscopic Studies of Uranium-Bearing Vadose Zone Sediments." In "Appendix D. Digest of Science and Technology Program Evaluations" in Field Investigation Report for Waste Management Area B-BX-BY. Volume 2, Appendices, AJ Knepp, pp. D-161 to D-187. RPP-10098, CH2M HILL Hanford Group, Inc., Richland, Washington. 


\subsection{Conclusions}

Important solution speciation, precipitation, and adsorption reactions were discussed for antimony, cobalt, europium, technetium, and uranium. Aqueous speciation and Eh-pH diagrams were calculated for each radionuclide using geochemical modeling techniques and the concentrations of natural ligands given in Kaplan et al. (1996) for the composition of an uncontaminated groundwater from the Hanford Site. These calculations identified the compositions of the dominant aqueous species and potential solubility controls for each radionuclide as a function of $\mathrm{pH}$ and redox conditions. The results of these calculations are presented in Table 7.1 relative to the oxidizing conditions that exist in the vadose zone at the Hanford Site.

Table 7.1. Selected Chemical and Transport Properties of Contaminants

\begin{tabular}{|c|c|c|c|c|c|c|c|}
\hline \multirow{3}{*}{ Element } & \multirow{3}{*}{$\begin{array}{l}\text { Isotope(s) } \\
\text { of Interest }\end{array}$} & \multicolumn{5}{|c|}{$\begin{array}{c}\text { Vadose Zone } \\
\text { (Oxidizing Conditions at pH } 8 \text { and Presence of Dissolved } \\
\text { Bicarbonate) }\end{array}$} & \multirow{3}{*}{$\begin{array}{l}\text { Is Mobility } \\
\text { Redox } \\
\text { Sensitive? }^{b}\end{array}$} \\
\hline & & \multicolumn{3}{|c|}{ Charge of Dominate Aqueous Species } & \multicolumn{2}{|c|}{ Expected Mobility a } & \\
\hline & & Cationic & Neutral & Anionic & Retarded & $\begin{array}{c}\text { Not } \\
\text { Retarded }\end{array}$ & \\
\hline Antimony & ${ }^{125} \mathrm{Sb}$ & & & $\mathrm{Sb}(\mathrm{OH})_{6}^{-}$ & & $\mathrm{x}$ & $\begin{array}{l}\text { Yes Sb(V) } \\
\mathrm{Sb}(\mathrm{III})\end{array}$ \\
\hline Cobalt & ${ }^{60} \mathrm{Co}$ & $\mathrm{Co}^{2+}$ & & & $\mathrm{x}$ & & $\begin{array}{l}\text { Yes }^{c} \\
\text { Co(III) } \\
\text { Co(II) }\end{array}$ \\
\hline Europium & $\begin{array}{l}{ }^{152} \mathrm{Eu} \\
{ }^{154} \mathrm{Eu}\end{array}$ & & $\mathrm{EuOHCO}_{3}{ }^{\circ}(\mathrm{aq})$ & & $\mathrm{x}$ & & No \\
\hline Technetium & ${ }^{99} \mathrm{Tc}$ & & & $\mathrm{TcO}_{4}^{-}$ & & $\mathrm{x}$ & $\begin{array}{l}\text { Yes Tc(VII) } \\
\text { Te(IV) }\end{array}$ \\
\hline Uranium & ${ }^{235} \mathrm{U}$ & & & $\mathrm{UO}_{2}\left(\mathrm{CO}_{3}\right)_{2}{ }^{2-}$ & $\begin{array}{c}x \\
\text { (limited) }\end{array}$ & & $\begin{array}{l}\text { Yes U(VI) } \\
\text { U(IV) }\end{array}$ \\
\hline \multicolumn{8}{|c|}{$\begin{array}{l}\text { a Retarded or attenuated (nonconservative) mobility means that the radionuclide moves slower than water through } \\
\text { geologic material. Nonretarded or nonattenuated (conservative) transport means that the contaminant moves at } \\
\text { the same rate as water. } \\
\text { b The redox status column identifies contaminants that have variable oxidation states within the pH and Eh limits } \\
\text { commonly found in the environment. } \\
\text { c Under most geochemical conditions, Co(II) is the stable valence state in water. Cobalt(III) is not } \\
\text { thermodynamically stable and decomposes under Eh-pH conditions common for most natural waters. However, } \\
\text { the presence of certain complexing ligands can stabilize Co(III) relative to reduction and allow it to persist in } \\
\text { aqueous solutions. }\end{array}$} \\
\hline
\end{tabular}

Under oxidizing conditions, the dominant aqueous species of $\mathrm{Sb}(\mathrm{V})$ and $\mathrm{Tc}(\mathrm{VII})$ do not change over the $\mathrm{pH}$ range of 3 and 10 under oxidizing conditions. Cobalt(II), Eu(III), and U(VI) have two or three different dominant species across this $\mathrm{pH}$ range. As $\mathrm{pH}$ increases, these aqueous complexes tend to become increasingly more negatively charged. For example, the dominant aqueous species of $\mathrm{Co}$ (II), 
$\mathrm{Eu}(\mathrm{III})$, and $\mathrm{U}(\mathrm{VI})$ are cationic at $\mathrm{pH}$ 3. At $\mathrm{pH}$ values greater than 7 , they exist predominantly as either neutral or anionic species. Typically, negatively charged aqueous species tend to adsorb less to sediments than their respective cationic species, because most minerals in sediments have a net negative charge in the range of $\mathrm{pH}$ values of most natural waters.

The effect of $\mathrm{pH}$ on both adsorption and precipitation of dissolved radionuclides and other metal contaminants is pervasive. The $\mathrm{pH}$ influences a number of aqueous and solid phase properties that directly affect the sorption to some degree of each radionuclide reviewed. The $\mathrm{pH}$ has a significant effect on the aqueous speciation of most radionuclides. The adsorption behavior of each radionuclide depends on the ionic charge and composition of its important aqueous species present in the environmental system being studied. Additionally, $\mathrm{pH}$ affects the number of adsorption sites on variable-charged minerals (aluminum- and iron-oxide minerals), formation of aqueous complexes, oxidation state of contaminants and complexing/precipitating ligands, $\mathrm{H}^{+} / \mathrm{OH}^{-}$competition for anionic or cationic adsorption sites, and partitioning of contaminants to organic matter.

The redox status of a system also dramatically influences the sorption behavior of antimony, cobalt, technetium, and uranium, because these radionuclides may exist in multiple oxidation states over the range of $\mathrm{pH}$-Eh conditions of natural waters. If the bulk redox potential of a sediment/water system is above the potential of the specific element redox reaction, the oxidized form of the redox sensitive element will exist. Below this critical value, the reduced form of the element will exist. Such a change in redox state can alter adsorption values (e.g., $K_{d}$ values) by several orders of magnitude, and can have direct and indirect effects on contaminant precipitation. The direct effect occurs with radionuclides, such as technetium, where the reduced species forms solid phases that are sparingly soluble compared to the oxidized reduced species. The indirect effects occur when the radionuclides adsorb to redox sensitive solid phases or precipitate with redox sensitive ligands. An example of the former involves the reductive dissolution of ferric oxide minerals, which can adsorb (complex) metals strongly. As the ferric oxide minerals dissolve, the adsorption potential of the sediment is decreased. Another indirect effect of redox on radionuclide sorption involves sulfur-ligand chemistry. Under reducing conditions, dissolved sulfur will exist as $\mathrm{S}(\mathrm{II})$ (sulfide, $\mathrm{S}^{2-}$ ), as opposed to $\mathrm{S}(\mathrm{VI})$ (sulfate, $\mathrm{SO}_{4}{ }^{2-}$ ); dissolved sulfide forms sparingly soluble sulfide minerals with some radionuclides and other dissolved metals.

\subsection{References}

Kaplan DI, RJ Serne, AT Owen, J Conca, TW Wietsma, and TL Gervais. 1996. Radionuclide Adsorption Distribution Coefficient Measured in Hanford Sediments for the Low Level Waste Performance Assessment Project. PNNL-11385, Pacific Northwest National Laboratory, Richland, Washington. 


\section{Distribution}

No. of

\section{Copies}

\section{OFFSITE}

Dr. Harry Babad

2540 Cordoba Court

Richland, WA 99352-1609

Pat Brady

Geochemistry Department, 6118

Sandia National Laboratories

P.O. Box 5800

Albuquerque, New Mexico 87185-0750

Charles R. Bryan

Sandia National Laboratories

4100 National Parks Highway

Carlsbad, N.M. 88220

Susan Carroll

Lawrence Livermore National Laboratory

Mail Stop L-219

Livermore, CA 94550

Jon Chorover

Associate Professor - Environmental

Chemistry

Department of Soil, Water and

Environmental Science

Shantz 429, Building \#38

University of Arizona

Tucson, AZ 85721-0038

Dave G. Coles

Coles Environmental Consulting

750 South Rosemont Rd

West Linn, OR 97068
No. of

Copies

Mark Conrad

Department of Earth and Planetary Sciences

University of California Berkeley

Berkeley, CA 94720

Dr. James A. Davis

U.S. Geological Survey

MS-465

345 Middlefield Rd.

Menlo Park, CA 94025

Donald J. DePaolo

Geology \& Geophysics Dept., MC4767

University of California

Berkeley, CA 94720-4767

Dirk A. Dunning

Oregon Office of Energy

625 Mariona St. N. E.

Salem, OR 97301-3742

Mark Ewanic

MSE Technology Applications, Inc.

200 Technology Way

Butte, MT 59701

Markus Flury

Department of Crop and Soil Sciences

Washington State University

Pullman, WA 99164

Amy P. Gamerdinger

2122 E. Hawthorne

Tucson, AZ 85719 
No. of

Copies

Jim Harsh

Department of Crop \& Soil Sciences

Washington State University

Johnson Hall - Room 249

Pullman WA 99164-6420

Dr. Cliff Johnston

Soil Chemistry and Mineralogy

1150 Lily Hall

Purdue University

West Lafayette, IN 47907-1150

Dr. Daniel I. Kaplan

Westinghouse Savannah River Company

Bldg. 774-43A, Rm 215

Aiken, SC 29808

Dr. Peter C. Lichtner

Los Alamos National Laboratory

P.O. Box 1663

Los Alamos, NM 87545

Patrick Longmire

Los Alamos National Laboratory

Mail Stop J534

P.O. Box 1663

Los Alamos, NM 87545

Kate Maher

The Center for Isotope Geochemistry

301 McCone Hall

University of California, Berkeley

Berkeley, CA 94702-4746

Melanie A. Mayes

Environmental Sciences Division

Oak Ridge National Laboratory

P.O. Box 2008

Oak Ridge,TN 37831-6038
No. of

Copies

Dr. Kathryn L. Nagy

Department of Earth and Environmental Sciences

University of Illinois at Chicago (MC-186)

845 West Taylor Street

Chicago, IL 60607-7059

Heino Nitsche

Director, Center for Advanced Environmental and Nuclear Studies

Lawrence Berkeley National Laboratory

1 Cyclotron Road

MS 70A-1150

Berkeley, CA 94720

Phil Reed

U.S. Nuclear Regulatory Commission

Office of Nuclear Regulatory Research

Division of Systems Analysis and Regulatory Effectiveness

Radiation Protection, Env. Risk and Waste Management Branch

Mail Stop: T9-F31

Washington, DC 20555-0001

Richard J. Reeder

Dept. of Geosciences

State University of New York at Stony Brook

Stony Brook, NY 11794-2100

Al Robinson

68705, E 715 PRNE

Richland WA 99352

Phil Rogers

13 Mountain Oak

Littleton, CO 80127

Distr.2 
No. of

Copies

David Shafer

Desert Research Institute

University of Nevada

P.O. Box 19040

Las Vegas, NV 89132-0040

Dawn A. Shaughnessy

Glenn T. Seaborg Center

Lawrence Berkeley National Laboratory

1 Cyclotron Road

MS 70A-1150

Berkeley, CA 94720

Doug Sherwood

Rivers Edge Environmental

1616 Riverside Drive

West Richland, WA 99353

David K. Shuh

Lawrence Berkeley National Lab

1 Cyclotron Road

Mail Stop 70A-1150

Berkeley, CA 94720

James "Buck" Sisson

Idaho National Engineering and

Environmental Laboratory

PO Box 1625, MS-2107

Idaho Falls, ID 83415-2107

Carl I. Steefel

Lawrence Livermore National Laboratory

Earth \& Environmental Sciences Directorate

Mail Stop L-204

PO Box 808

Livermore, CA 94551-9900

Dr. Samuel J. Traina, Director

Sierra Nevada Research Institute

University of California, Merced

P.O. Box 2039

Merced, CA 95344
No. of

Copies

Dr. T. T. Chuck Vandergraaf

Atomic Energy Of Canada, Limited

Whiteshell Nuclear Research Establishment

Pinawa, Manitoba ROE 1LO

Canada

Dr. Jiamin Wan

Lawrence Berkeley National Laboratory

1 Cyclotron Rd. MS 70-0127A

Berkeley, CA 94720

Mr. Ronald G. Wilhelm

Office of Radiation and Indoor Air

401 M Street, S.W.

Mail Code 6603J

Washington, D.C. 20460

W. Alexander Williams

US Department of Energy

Office of Environmental Restoration

EM-33

19901 Germantown Road

Germantown, MD 20874-1290

\section{ONSITE}

4 DOE Office of River Protection
C. A. Babel
H6-60
P. E. LaMont
H6-60
R. W. Lober
H6-60
R. B. Yasek
H6-60

8 DOE Richland Operations Office

$\begin{array}{ll}\text { B. L. Foley } & \text { A6-38 } \\ \text { J. P. Hanson } & \text { A5-13 } \\ \text { R. D. Hildebrand } & \text { A6-38 } \\ \text { K. A. Kapsi } & \text { A5-13 } \\ \text { J. G. Morse } & \text { A6-38 } \\ \text { K. M. Thompson } & \text { A6-38 } \\ \text { DOE Public Reading Room (2) } & \text { H2-53 }\end{array}$

B. L. Foley

6-38

A5-13

A6-38

A5-13

A6-38

DOE Public Reading Room (2)

Distr.3 
No. of

Copies

Bechtel Hanford, Inc.

K. R. Fecht H0-02

18 CH2M Hill Hanford Group, Inc.

J. E. Auten

E6-35

K. C. Burgard

L6-57

M. P. Connelly

E6-35

E. A. Fredenburg

H9-03

T. E. Jones (2)

E6-35

H6-60

A. J. Knepp (2)

E6-35

F. M. Mann (5)

E6-35

W. J. McMahon

H9-03

C. W. Miller

E6-35

3 Duratek Federal Services, Inc., Northwest Operations

M. G. Gardner

H1-11

K. D. Reynolds

H1-11

D. E. Skoglie

H1-11

3 Environmental Protection Agency

Nick Ceto

B5-01

D. A. Faulk

B5-01

M. L. Goldstein

B5-01

2 Flour Federal Services

R. Khaleel

E6-17

R. J. Puigh

E6-17

5 Flour Hanford, Inc.

T. W. Fogwell

E6-35

B. H. Ford

E6-35

J. G. Hogan

H1-11

V. G. Johnson

E6-35

M. I. Wood

H8-44
No. of

Copies

R. W. Bryce E6-35

R. E. Clayton P7-22

W. J. Deutsch K6-81

P. E. Dresel K6-96

K. M. Geisler P7-22

M. J. Fayer K9-33

A. R. Felmy K8-96

M. D. Freshley K9-33

J. S. Fruchter K6-96

D. G. Horton K6-81

J. P. Icenhower K6-81

C. T. Kincaid E6-35

K. M. Krupka K6-81

I. V. Kutnyakov P7-22

G. V. Last (3) K6-81

V. L. LeGore P7-22

M. J. Lindberg P7-22

C. W. Lindenmeier (2) P7-22

W. J. Martin K6-81

S. V. Mattigod K6-81

B. P. McGrail K6-81

P. D. Meyer BPO

C. J. Murray K6-81

S. M. Narbutovskih K6-96

R. D. Orr K6-81

E. M. Pierce K6-81

S. P. Reidel K6-81

R. J. Serne (20) P7-22

H. T. Schaef K6-81

W. Um P7-22

M. Valenta P7-22

T. S. Vickerman P7-22

B. A. Williams K6-81

S. B. Yabusaki K9-36

J. M. Zachara K8-96

Hanford Technical Library (2) P8-55

64 Pacific Northwest National Laboratory
S. R. Baum
P7-22
B. N. Bjornstad (3)
K6-81
C. F. Brown
P7-22 